\title{
21. NEOGENE CARBONATE STRATIGRAPHY OF HESS RISE (CENTRAL NORTH PACIFIC) AND PALEOCEANOGRAPHIC IMPLICATIONS ${ }^{1}$
}

\author{
Edith Vincent, Scripps Institution of Oceanography, Geological Research Division, La Jolla, California
}

\begin{abstract}
A detailed Neogene carbonate stratigraphy obtained from Hess Rise, in the temperate zone of the North Pacific, allows a cross-latitudinal correlation of carbonate fluctuations throughout the Pacific. The correlations are based on paleomagnetically dated biostratigraphic events.

The carbonate record at Site 310, on Central Hess Rise, at a water depth of about 3500 meters, was obtained with a sampling interval representing time intervals of roughly 20,000 years in the Plio-Pleistocene, 30,000 years in the uppermost Miocene younger than about 6.2 m.y., and 140,000 years in the remainder of the upper Miocene and the middle Miocene. This record allows identification at Site 310 of specific carbonate events recognized throughout the equatorial Pacific, showing the ocean-wide nature of these events. The carbonate records compared with Site 310 are based on (time-) sampling intervals similar to those of Site 310. The comparison records are all located in the high-productivity belt of the equatorial Pacific, from depths near 2000 meters in the Panama Basin (DSDP Sites 157 and 158) to depths near 4500 meters, not far above the CCD (various piston cores). Specific carbonate events were not detected in the Plio-Pleistocene carbonate record at Site 466 , on southern Hess Rise. This record was obtained with a sampling interval equivalent to a time span of about 60,000 years. This site, located at a water depth of about 2700 meters, has a Plio-Pleistocene sedimentary history similar to that at nearby Site 310, with approximately the same accumulation rate.

Long-term cycles are superimposed on the short-term carbonate fluctuations in the equatorial Pacific sequences. The periodicity of these cycles, although not regular, is on the order of $0.5 \mathrm{~m} . \mathrm{y}$. for the upper Pleistocene, and on the order of 1 to 1.5 m.y. for the lower Pleistocene, Pliocene, and Miocene. Some of these long-term cycles are apparent in the carbonate stratigraphy at Site 310, especially in the Pleistocene and Miocene, but are not seen in the Pliocene. In Cores V24-59 and RC12-66, the Gauss includes the interval with the lowest calcium carbonate content of the entire Neogene, and sediment in this sequence accumulated more slowly than before or after. In contrast, at both Sites 310 and 157 , this sequence accumulated at an average rate higher than overlying and underlying sediments. At Site 310 , it contains the highest $\mathrm{CaCO}_{3}$ average concentration of the entire Neogene.

At Sites 310 and 466, there is an overall correlation between lower carbonate content and poorer foraminifer preservation in the Pleistocene, but no such correlation exists in the Pliocene and upper Miocene.

"Dissolution spikes" were found to be associated with climatic deterioration (marked by a distinct ${ }^{18} \mathrm{O}$ enrichment in benthic foraminifers) and with a lightening in the benthic carbon-isotope record. They appear to be of global significance. These excursions provide chemostratigraphic signals of utmost importance for chronostratigraphic correlations. This does not imply, however, that carbonate fluctuations were produced by only one or two master variables. At different times, the mix of processes responsible for the carbonate-fluctuation patterns may have varied considerably.
\end{abstract}

\section{INTRODUCTION}

Cyclic fluctuations in carbonate content of Pleistocene sediments have offered an excellent fine-scale stratigraphic tool allowing correlations across the entire equatorial Indo-Pacific (Arrhenius, 1952; Olausson, 1960; Oba, 1969; Hays et al., 1969; Thompson and Saito, 1974; Luz and Shackleton, 1975; Ninkovich and Shackleton, 1975; Thompson, 1976; Adelseck, 1977; Valencia, 1977; Adelseck and Anderson, 1978; Thompson and Sciarrillo, 1978; Mayer, 1979; Volat et al., 1980). The mechanisms governing these carbonate fluctuations in ocean geochemistry, however, are still largely unknown. The carbonate cycles are correlative to climatic oscillations, as originally postulated by Arrhenius (1952), high-carbonate sediments corresponding to glacial intervals and low-carbonate sediments to warmer interglacials. The various hypotheses linking Pleistocene carbonate cycles and paleoclimatic fluctuations in the equatorial Pacific recently have been reviewed by Volat et al. (1980). Ar-

\footnotetext{
${ }^{1}$ Initial Reports of the Deep Sea Drilling Project, Volume 62.
}

rhenius (1952) related these carbonate cycles to productivity fluctuations, whereas Broecker (1971) and Berger (1973), following an earlier suggestion of Olausson (1965), interpreted them as controlled by solution variations. Shackleton (1977) suggested that changes in world vegetation lead to variation in the $\mathrm{CO}_{2}$ content of the atmosphere-ocean system, and as a consequence to variation in carbonate preservation. Berger (1977) extended this hypothesis to include soil carbon and other reactive carbon pools, and discusses other possibilities.

Despite the successful use of Pleistocene carbonate stratigraphy, few studies on pre-Pleistocene carbonate stratigraphy have been made. The cyclicity in carbonate variations in the equatorial Pacific extends down throughout the Pliocene and the upper Miocene, and has also been shown to correlate between various sequences of the equatorial Pacific (Hays et al., 1969; Kaneps, 1973b; Saito et al., 1975; Dunn and Moore, 1981). In this ocean basin, however, extremely few data on Pleistocene and pre-Pleistocene carbonate fluctuations are available from outside the equatorial area.

The purpose of this study is to present for the first time a detailed carbonate stratigraphy of upper Neogene 
sediments from the mid-latitudes of the Pacific Ocean. This carbonate record is compared through biostratigraphic correlations to the paleomagnetically dated carbonate stratigraphy of the equatorial Pacific, in order to identify ocean-wide carbonate events. To further help detect Mio-Pliocene global signals in carbonate preservation, the carbonate record is compared to another chemical signal of global significance, the isotope record. The synchronism or diachronism of a number of paleontological events in temperate and equatorial areas is evaluated by comparing biostratigraphic and chemostratigraphic correlations. The importance of global chemostratigraphic signals for chronostratigraphic correlations has been recently emphasized (Berger and Vincent, 1981).

\section{MATERIAL AND APPROACH}

A detailed carbonate stratigraphy of DSDP Sites 310 and 466, located on Hess Rise (Table 1, Fig. 1), was produced at Scripps Institution of Oceanography for comparison with other, similar detailed stratigraphies. The carbonate curves chosen for comparison were selected on the basis of continuity of the sedimentary sequences and detailed studies of their biostratigraphy, magnetostratigraphy, and oxygen- and carbon-isotope stratigraphy. These sequences include five piston cores and two DSDP sites, all located in the equatorial Pacific (Table 1, Figure 1). They lie at water depths covering a wide range, from a shallow depth (Site 158) to depths close to the CCD, which is near 5000 meters in the equatorial Pacific (Berger and Winterer, 1974). Sources of data are given in Table 2.

DSDP Sites 310 and 466 , in the mid-latitudes of the central North Pacific, are both located on Hess Rise, at water depths of 3500 and 2700 meters, respectively. Site 310 , on central Hess Rise (Larson, Moberly, et al., 1975), lies beneath the boundary between central and transitional water masses, whereas Site 466 , on southern Hess Rise, lies beneath the northern boundary of the central water mass. Both sites have a well-developed Plio-Pleistocene sequence of calcareous ooze, which accumulated at an average rate of $13 \mathrm{~m} / \mathrm{m}$.y. (Site 310) to $15 \mathrm{~m} / \mathrm{m} . \mathrm{y}$. (Site 466). At Site 466, a major unconformity separates this sequence from Oligocene sediments, whereas at Site 310 a condensed middle and upper Miocene section overlies the Oligocene unconformably.

Table 1. Location of DSDP sites and piston cores used in this study.

\begin{tabular}{lccc}
\hline Site or Core & Latitude & Longitude & $\begin{array}{c}\text { Water } \\
\text { Depth } \\
(\mathrm{m})\end{array}$ \\
\hline DSDP 310 & $36^{\circ} 52^{\prime} \mathrm{N}$ & $176^{\circ} 54^{\prime} \mathrm{E}$ & 3516 \\
DSDP 466 & $34^{\circ} 11^{\prime} \mathrm{N}$ & $179^{\circ} 15^{\prime} \mathrm{E}$ & 2665 \\
DSDP 157 & $1^{\circ} 45^{\prime} \mathrm{S}$ & $85^{\circ} 54^{\prime} \mathrm{W}$ & 2591 \\
DSDP 158 & $6^{\circ} 37^{\prime} \mathrm{N}$ & $85^{\circ} 14^{\prime} \mathrm{W}$ & 1953 \\
RC11-209 & $3^{\circ} 39^{\prime} \mathrm{N}$ & $140^{\circ} 04^{\prime} \mathrm{W}$ & 4400 \\
RC12-65 & $4^{\circ} 39^{\prime} \mathrm{N}$ & $144^{\circ} 58^{\prime} \mathrm{W}$ & 4868 \\
RC12-66 & $2^{\circ} 36^{\prime} \mathrm{N}$ & $148^{\circ} 12^{\prime} \mathrm{W}$ & 4755 \\
V24-58 & $2^{\circ} 16^{\prime} \mathrm{N}$ & $141^{\circ} 40^{\prime} \mathrm{W}$ & 4490 \\
V24-59 & $2^{\circ} 34^{\prime} \mathrm{N}$ & $145^{\circ} 32^{\prime} \mathrm{W}$ & 4662 \\
\hline
\end{tabular}

At both sites, calcium carbonate content was measured (with an accuracy of $1 \%$ relative) by a gasometric technique in which the volume of $\mathrm{CO}_{2}$ evolved from the reaction of carbonate with hydrochloric acid is measured. Sampling was performed at a $30-\mathrm{cm}$ interval at Site 310 , and a $75-$ to $100-\mathrm{cm}$ interval at Site 466 . This sampling interval in the Plio-Pleistocene represents a time interval of about 23,000 years at Site 310 , and about 50,000 to 70,000 years at Site 466 . In the uppermost Miocene at Site 310, which accumulated at an average rate of $10 \mathrm{~m} / \mathrm{m} . \mathrm{y}$., the sampling interval represents about 30,000 years; in the middle Miocene and upper Miocene older than about $6.2 \mathrm{~m} . \mathrm{y}$., which accumulated at an average rate of $2 \mathrm{~m} / \mathrm{m}$.y., it represents a time interval of about 150,000 years. Values of calcium carbonate content at Site 310 are given in Table 3 and plotted against sub-bottom depths in Figure 2, together with the isotope stratigraphy of benthic foraminifers obtained at this site by Keigwin (1979) and various biostratigraphic zonations (that of R. Schmidt for calcareous nannofossils was established from subsamples of the samples used in this study). Values of calcium carbonate content at Site 466 are given in Vincent (this volume) and are plotted against sub-bottom depth and biostratigraphy (Fig. 3).

Sites 157 and 158, drilled in the easternmost tropical Pacific in the Panama Basin (van Andel et al., 1973), recovered thick sequences (over $300 \mathrm{~m}$ thick) of Pleistocene to upper and middle Miocene calcareous-siliceous ooze grading into chalk down-core, with cherts above basaltic basement. Site 158, at a water depth of 1953 meters, is in an area dominated by the influence of the Equatorial Countercurrent, whereas Site 157, at a water depth of 2591 meters, is under the influence of the Equatorial Divergence and the Peru-Chile Current. Accumulation rates at both sites are high, reflecting the high organic productivity of this area of coastal upwelling. At Site 157 the average accumulation rate for the entire sedimentary sequence, which is apparently continuous, is close to $60 \mathrm{~m} / \mathrm{m}$.y. At Site 158 , upper Pleistocene sediments accumulated at an average rate of about $39 \mathrm{~m} / \mathrm{m} . y$. Here, the lower Pleistocene to upper Pliocene section is very condensed and includes a hiatus spanning the Pliocene/Pleistocene boundary. The lowermost Pliocene and uppermost Miocene accumulated at an average rate of about $42 \mathrm{~m} / \mathrm{m} . \mathrm{y}$, whereas the upper Miocene older than about $6.2 \mathrm{~m}$.y. and middle Miocene accumulated at an average rate of about $18 \mathrm{~m} / \mathrm{m} . \mathrm{y}$.

Carbonate content at both Sites 157 and 158 was determined at intervals generally of $150 \mathrm{~cm}$ by Bode and Cronan (1973), using the Leco 70-second carbon analyzer. Carbonate curves obtained from these data are plotted in Figures 4 and 5. The time interval represented by the sampling interval at Site 157 is roughly 25,000 years. At Site 158, it is about 37,000 years for the upper Pleistocene and the lowermost Pliocene to uppermost Miocene, and about 84,000 years for the upper Miocene older than $6.2 \mathrm{~m} . \mathrm{y}$. and the middle Miocene. Most of the Plio-Pleistocene sequence is very condensed at Site 158 and includes a substantial hiatus; therefore, the carbonate stratigraphy of the upper 75 meters is not con- 


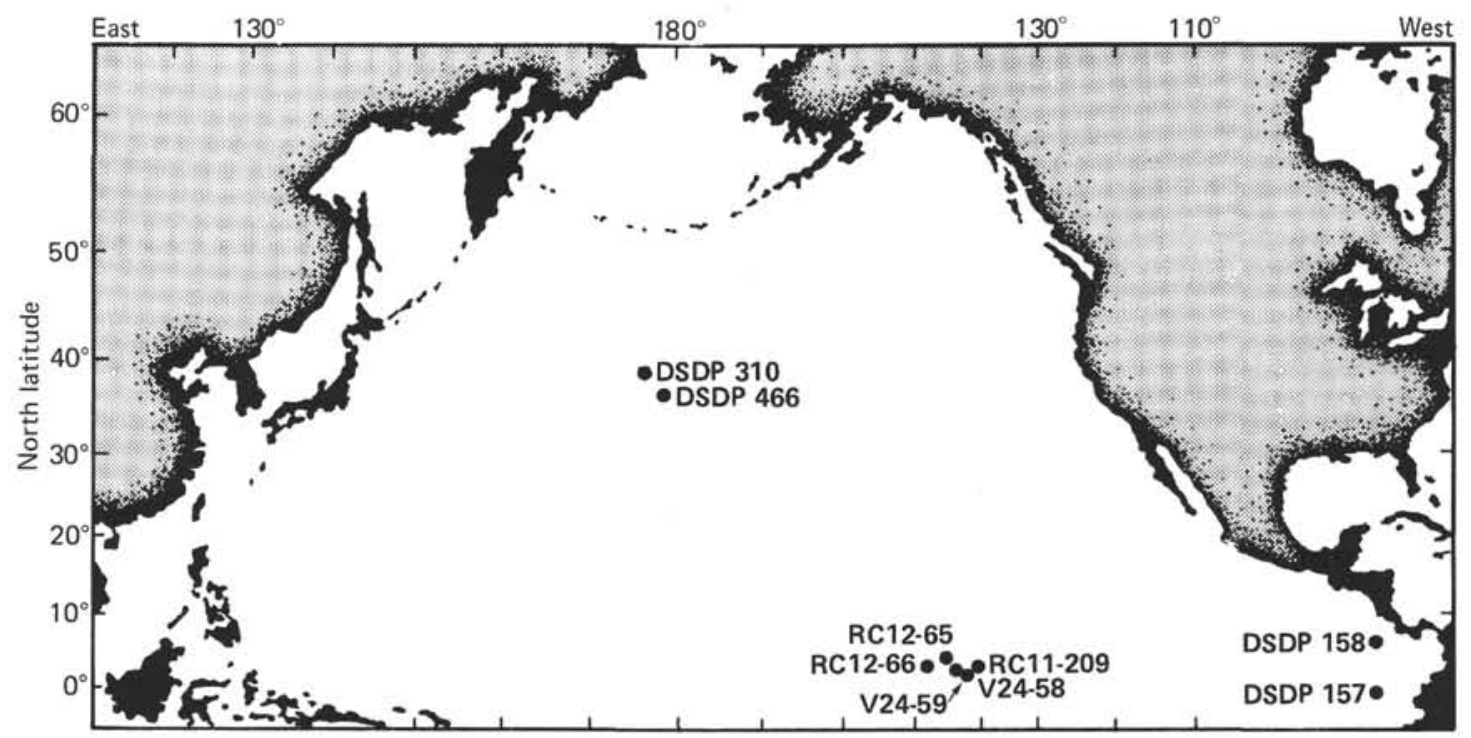

Figure 1. Locations of DSDP sites and piston cores used in this study.

sidered in this paper, and only the section below 75 meters - that is the lowermost Pliocene and Miocene-is analyzed in detail. Carbonate data are not available below about 300 meters at both Sites 157 and 158 . Below that level, the chalk is indurated and chert caused poor core recovery. The carbonate stratigraphy at Site 157 was discussed in some detail by Kaneps (1973b). Dunn and Moore (1981) re-analyzed the upper Miocene section at Site 158 and obtained additional calcium carbonate data with a closer sampling interval, using the revised "Karbonat-Bombe" technique (Dunn, 1980). Part of their data is shown in Figure 5.

All studied piston cores are from the high-productivity belt of the equatorial Pacific, close to the axis of the lens of thick sediments which underlies this region (Ewing et al,, 1968). Cores RC11-209 and V24-58 are in the area of maximum sediment thickness, whereas Cores RC12$66, \mathrm{RC} 12-65$, and $\mathrm{V} 24-59$ are just to the west of this maximum. These cores, all raised from water depths greater than 4000 meters-well below the lysocline-are composed of alternating layers of calcareous ooze and siliceous calcareous ooze. Cores RC11-209 and V24-58 recovered a Pleistocene sequence, whereas Core V24-59 penetrated into the Pliocene, and Cores RC12-66 and RC12-65 into the upper Miocene.

Calcium carbonate content was measured in these cores by Hays et al. (1969) and Saito et al. (1975) at $10-\mathrm{cm}$ intervals by the rapid gasometric technique of Hülseman (1966). The two shallowest cores, RC11-209 and V24-58, from approximately 4400 meters water depth, accumulated at an average accumulation rate of 7.4 and $5.5 \mathrm{~m} / \mathrm{m} . \mathrm{y}$. , respectively. The sampling interval in these cores represents time intervals of about 13,000 and 18,000 years, respectively, and the carbonate stratigraphy shows well-defined carbonate cycles (Fig. 6). In the two deeper cores, V24-59 and RC12-66, from a water depth of about 4700 meters, evidence of solution is much greater, and the carbonate cycles are less clear.
These two cores have an almost identical carbonate stratigraphy pattern (Fig. 7). The average accumulation rate for both entire cores is approximately 3 and $4 \mathrm{~m} / \mathrm{m}$.y., respectively, and the sampling interval represents time intervals of roughly 33,000 to 25,000 years.

Core RC12-65, from a water depth of over 4800 meters, is virtually carbonate-free for most of its length, except in the intervals above 2 meters (in the Brunhes), and between 11 and 21 meters (Epoch 6 to Epoch 9). Only the latter, upper Miocene interval is considered here (Fig. 7). This entire interval accumulated at an average rate of approximately $2.5 \mathrm{~m} / \mathrm{m}$.y., and the sampling interval represents a time interval of about 40,000 years.

Biostratigraphic events for various fossil groups for each studied piston core and DSDP site are compiled in Tables 4 to 11 and were used for correlation between the paleomagnetically dated piston cores and the DSDP sites. The reliability of these events was critically evaluated according to their known calibration to the paleomagnetic time scale (Table 12).

Following Jenkins $(1966,1971)$ and Hornibrook and Edwards (1971), the datum-level concept has been emphasized in biostratigraphy during the last decade (e.g., Hays et al., 1969; Berggren, 1973; Berggren and Van Couvering, 1974; Ryan et al., 1974; Theyer and Hammond, 1974; Saito et al., 1975; Van Couvering et al., 1976; Burckle, 1977, 1978; Saito, 1977; Vincent, 1977b; Berggren and Van Couvering, 1978; among others) High-resolution biochronologic frameworks recently have been developed for the late Neogene by the integration of FADs (first appearance datums) and LADs (last appearance datums) of species from various fossil groups; these FADs and LADs were directly calibrated to the radiometric-magnetic time scale or their ages were approximated by extrapolation from sedimentation rates (e.g., Berggren and Van Couvering, 1974; Ryan et al., 1974). 
Table 2. Sources of data used in this study.

\begin{tabular}{|c|c|c|c|c|}
\hline $\begin{array}{l}\text { Site or } \\
\text { Core }\end{array}$ & $\begin{array}{l}\text { Planktonic } \\
\text { Foraminifers }\end{array}$ & $\begin{array}{l}\text { Calcareous } \\
\text { Nannofossils }\end{array}$ & Radiolarians & Diatoms \\
\hline DSDP 310 & $\begin{array}{l}\text { Vincent }(1975,1977 a) \\
\text { Keller }(1978,1979,1980)\end{array}$ & $\begin{array}{l}\text { Bukry (1975, pers. comm.); } \\
\text { Schmidt (pers. comm.) }\end{array}$ & Foreman (1975) & $\begin{array}{l}\text { Koizumi (1975); } \\
\text { Burckle (pers. comm.); } \\
\text { Baron (pers. comm.) }\end{array}$ \\
\hline DSDP 466 & Vincent (this volume) & Schmidt (this volume) & Schaaf (this volume) & Sancetta (this volume) \\
\hline DSDP 157 & $\begin{array}{l}\text { Kaneps (1973a); } \\
\text { Keigwin (1976) }\end{array}$ & Bukry (1973) & Dinkelman (1973) & Burckle (1978) \\
\hline DSDP 158 & $\begin{array}{l}\text { Kaneps (1973a); } \\
\text { Keigwin (1976) }\end{array}$ & Bukry (1973) & Dinkelman (1973) & $\begin{array}{l}\text { Burckle and Opdyke (1977); } \\
\text { Burckle (pers. comm.) }\end{array}$ \\
\hline RC11-209 & Thompson and Sciarrillo (1978) & & Johnson and Knoll (1975) & Burckle (1977) \\
\hline $\mathrm{RC} 12-65$ & & Ryan et al. (1974) & $\begin{array}{l}\text { Saito et al. (1975); } \\
\text { Opdyke (1972) }\end{array}$ & $\begin{array}{l}\text { Saito et al. (1975); } \\
\text { Burckle (pers. comm.) }\end{array}$ \\
\hline $\mathrm{RC} 12-66$ & $\begin{array}{l}\text { Saito et al. (1975); } \\
\text { Thompson and Sciarrillo (1978) }\end{array}$ & Gartner (1973) & Saito et al. (1975) & $\begin{array}{l}\text { Saito et al. (1975); } \\
\text { Burckle (1978, pers. comm.) }\end{array}$ \\
\hline V24-58 & $\begin{array}{l}\text { Hays et al. (1969); } \\
\text { Thompson and Sciarrillo (1978) }\end{array}$ & Gartner (1973) & $\begin{array}{l}\text { Hays et al. (1969); } \\
\text { Johnson and Knoll (1975) }\end{array}$ & \\
\hline V24-59 & Hays et al. (1969) & Gartner (1973) & $\begin{array}{l}\text { Hays et al. (1969); } \\
\text { Casey and Reynolds (1980) }\end{array}$ & Hays et al. (1969) \\
\hline
\end{tabular}

Slight differences occur in the chronologies proposed by various authors for the paleomagnetic "time scale," depending on the methodology used for estimating ages of paleomagnetic epoch boundaries (e.g., Opdyke, 1972; Berggren and Van Couvering, 1974; Opdyke et al., 1974; Ryan et al., 1974; Theyer and Hammond, 1974; followed by Theyer et al. 1978; La Brecque et al., 1977; Mankinen and Dalrymple, 1979). Thus, different schemes have been used by various authors for assigning ages to biostratigraphic datums calibrated to the magnetic time scale. Slight discrepancies occur therefore in absolute ages assigned by different workers to the same biostratigraphic event occupying a specific position in the magnetostratigraphic sequence. This should be kept in mind in reading "absolute age" values given in this paper, which should be considered only approximate. In Table 12 an attempt has been made to follow Mankinen and Dalrymple's (1979) paleomagnetic time scale for age assignments. More important than these values is the position of biostratigraphic events in the magnetostratigraphic sequence, as well as their relative position in regard to other biostratigraphic events. As pointed out by Theyer et al. (1978), "at the present stage, the most important facet is not so much the absolute chronology, but the direct (that is, within the same material) calibration of the biostratigraphic events against an independent system of discrete events of global character, such as magnetic reversals."

Other independent means useful for calibration of biostratigraphic events on a global scale are provided by geochemical signals such as the stable-isotope record of calcareous fossils, especially foraminifers. Through much of the Neogene, when ice-volume fluctuations exerted strong control on variations in ${ }^{16} \mathrm{O} /{ }^{18} \mathrm{O}$ ratios, the oxygen-isotope signal is clearly global and can be used to establish synchroneity of biostratigraphic datums (e.g., Hays and Shackleton, 1976; Thierstein et al., 1977). Variations in the ${ }^{12} \mathrm{C} /{ }^{13} \mathrm{C}$ ratios of foraminifers are more difficult to interpret, but substantial excursions also may be worldwide. An abrupt depletion of about $0.8 \%$ in the $\delta^{13} \mathrm{C}$ isotopic composition of benthic foraminifers occurs in the upper Miocene (within Magnetic Epoch 6) of a number of deep-sea sequences (Keigwin, 1979; Keigwin and Shackleton, 1980; Haq et al., 1980; Vincent et al., 1980). This carbon-isotope event involved both deep and shallow waters (Vincent et al., 1980), and hence the entire ocean. The occurrence of the "Epoch 6 Carbon Shift" in Core RC12-66 and Sites 310 and 158 is here used for chronostratigraphic correlation between these three sequences (see Tables 7 , 10, 11 and 12, and Fig. 7).

\section{CARBONATE STRATIGRAPHY}

\section{Introduction}

Hess Rise is among the very few structural units of the North Pacific sufficiently elevated above the abyssal seafloor to yield carbonate sections. Sites 310 and 466, drilled on central and southern Hess Rise, respectively, provide the best-suited Neogene carbonate records from the middle latitudes of this ocean basin for comparison with those of the equatorial region.

Carbonate records of the equatorial Pacific show distinct cyclic fluctuations throughout the Pleistocene and Plio-Miocene. Hays et al. (1969) identified eight carbonate cycles throughout the Brunhes series, having periodicities of about 75,000 years in the upper Brunhes to over 100,000 years in the lower Brunhes. Below the Brunhes, down to the top of the Olduvai event, they identified 7 cycles with an average period of about 100,000 years, but the periodicity of these cycles is not as regular as those of the Brunhes. In the two shallowest cores of their study, RC11-209 and V24-58, the carbonate cycles are well defined, whereas in the condensed sequences of the two deepest cores, V24-59 and V24-62, the carbonate cycles are less clear.

Hays et al. (1969) established a carbonate terminology naming specific carbonate minima and maxima with a letter-number system, according to their sequential order within each magnetic-polarity epoch, odd numbers identifying low-carbonate peaks, and even numbers high-carbonate peaks. They identified carbon- 
Table 2. (Continued).

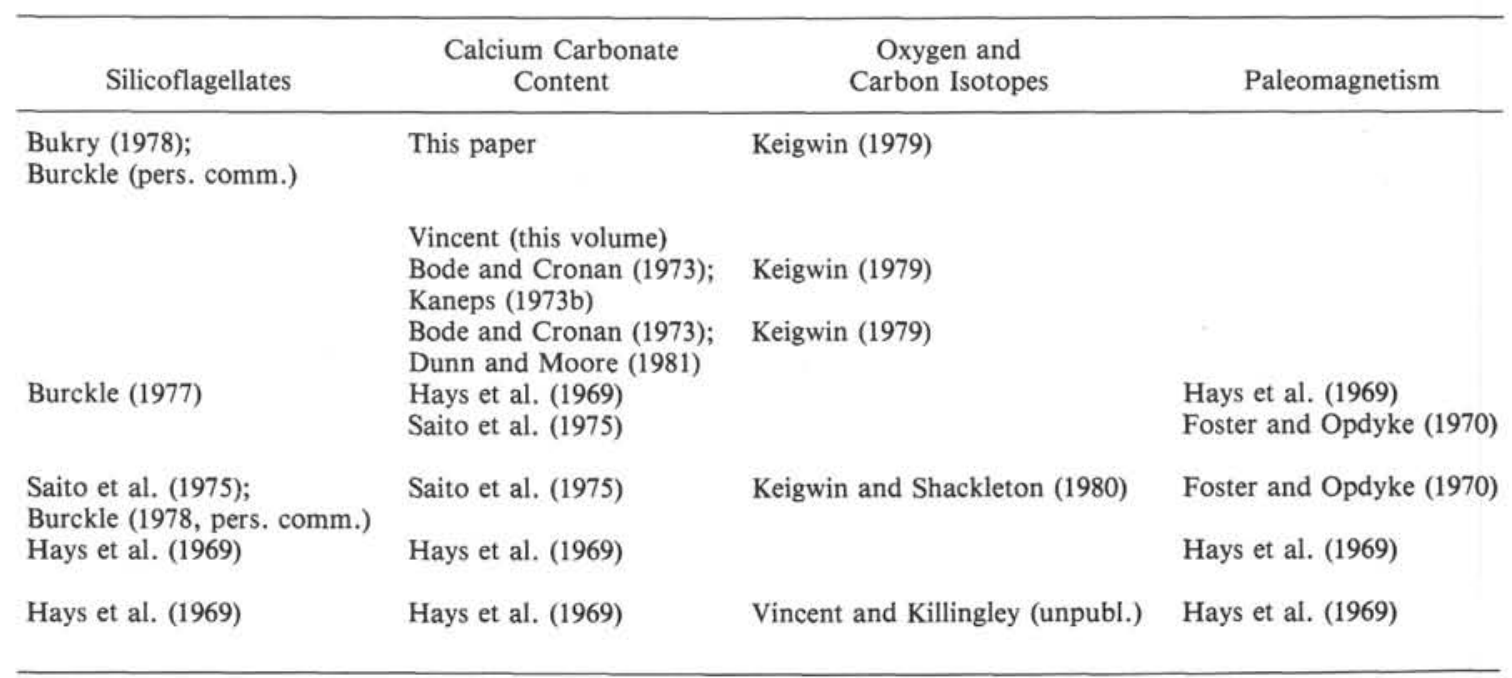

ate cycles in the Pliocene down to the Gilbert $\mathrm{C}$ event in Core V24-59, and extended their terminology for specific carbonate minima and maxima down to GU3 in the middle of the Gauss.

Saito et al. (1975) found that the carbonate stratigraphy of Core RC12-66, located at a water depth close to that of Core V24-59, has a pattern almost identical to that of the latter core. These authors identified carbonate cycles further down in Core RC12-66, into the lower Pliocene and upper Miocene. They noted within the Epoch 5 series (an interval of high calcium carbonate content) 10 to 13 cycles having a periodicity of 77,000 to 100,000 years, similar to that of the Brunhes cycles.

Kaneps (1973b) correlated the Plio-Pleistocene carbonate stratigraphies of RC12-66 and DSDP Site 157 and found a close similarity between those and that of DSDP Site 132 in the Mediterranean Sea. He extended the carbonate nomenclature below GU3 to the lower Gilbert and informally named 25 carbonate peaks and troughs designated by lowercase letters.

Dunn and Moore (1981) re-evaluated the carbonate stratigraphy established by Saito et al. (1975) in Cores $\mathrm{RC} 12-66$ and RC12-65. They replaced the informal nomenclature of Kaneps (1973b) by formally naming the Gilbert carbonate events using the terminology of Hays et al. (1969); they pointed out 10 cycles in the Gilbert with a duration of 195,000 to 500,000 years. Dunn and Moore (1981) recognized in the upper Miocene carbonate stratigraphy of RC12-66 and RC12-65 cycles with a 150,000 years duration, which they utilize to extend the carbonate terminology back to Magnetic Epoch 9 . These authors named the minima and maxima of these carbonate cycles according to the magnetic-polarity epoch in which they occur, the polarity-epoch number followed by a sequential series of lowercase letters with carbonate minima denoted by a, c, e. . . and carbonate maxima by b, d, f, etc. They identified 37 specific upper Miocene carbonate events (10 in Epoch 5, 11 in Epoch
6, 7 in Epoch 7, 5 in Epoch 8, and 4 in Epoch 9). By using the graphic correlation method of Shaw (1964) and biostratigraphic correlations, Dunn and Moore (1981) were able to correlate upper Miocene carbonate curves of two DSDP sites (158 and 77B) with those of the two piston cores.

Cyclic carbonate fluctuations in the equatorial $\mathrm{Pa}$ cific have been shown to extend back into the middle Miocene (Tracey, Sutton et al., 1971, p. 158).

The carbonate stratigraphy of Sites 310 and 466 on Hess Rise shows the same overall trend at both sites throughout the Plio-Pleistocene, that is, a slight upward-decreasing trend from a higher carbonate content in the lower Pliocene, to slightly lower values in the upper Pliocene, and minimum values in the upper Pleistocene. At Site 466, the carbonate content ranges from 95 to $75 \%$, with two lower values close to $70 \%$ at 27.5 and 16 meters, respectively, and a low-carbonate peak (about $55 \%$ ) in the upper Pleistocene at 2.5 meters. The average level of carbonate content at Site 310 is slightly lower than at Site 466 , probably owing to the greater water depth at Site 310. The carbonate curve at Site 310 looks much noisier than that at Site 466 , as it is based on a closer sampling interval. At Site 310, the average carbonate content in the Miocene through the lower Pleistocene is from about 90 to $70 \%$, with pronounced excursions toward low carbonate values, as low as $50 \%$ or less; the average carbonate level in the upper Pleistocene is about $55 \%$, with excursions as low as $35 \%$.

Long-term carbonate cycles are not immediately as apparent at Site 310 as they are in the piston cores from the equatorial Pacific, where dissolution is much more pronounced, and in Sites 157 and 158, in a region of higher organic productivity. In order to estimate whether short-term carbonate fluctuations observed at Site 310 are synchronous with those of the equatorial Pacific, carbonate records from both Site 310 and the equatorial region, obtained from sampling intervals representing similar time intervals, are now compared 


\section{E. VINCENT}

Table 3. Calcium carbonate content in Neogene sediments at DSDP Site 310.

\begin{tabular}{|c|c|c|}
\hline $\begin{array}{c}\text { Sample } \\
\text { (interval in } \mathrm{cm} \text { ) }\end{array}$ & $\begin{array}{l}\text { Sub-bottom } \\
\text { Depth } \\
\text { (m) }\end{array}$ & $\begin{array}{c}\mathrm{CaCO}_{3} \\
(\%)\end{array}$ \\
\hline $310-1-1,0-2$ & 0.0 & 64.0 \\
\hline $310-1-1,19-21$ & 0.19 & 58.2 \\
\hline $310-1-1,52-54$ & 0.52 & 66.8 \\
\hline $310-1-1,78-80$ & 0.78 & 72.8 \\
\hline $310-1-1,109-111$ & 1.09 & 61.1 \\
\hline $310-1-1,143-144$ & 1.43 & 62.6 \\
\hline $310-1-2,2-4$ & 1.52 & 66.2 \\
\hline $310-1-2,36-38$ & 1.86 & 58.4 \\
\hline $310-1-2,64-66$ & 2.14 & 45.9 \\
\hline $310-1-2,94-96$ & 2.44 & 35.1 \\
\hline $310-1-2,129-131$ & 2.79 & 54.2 \\
\hline $310-1-3,17-19$ & 3.17 & 49.0 \\
\hline $310-1-3,31-33$ & 3.31 & 52.0 \\
\hline $310-1-3,58-60$ & 3.58 & 28.0 \\
\hline $310-1-3,93-96$ & 3.93 & 48.6 \\
\hline $310-1-3,98-100$ & 3.98 & 62.2 \\
\hline $310-1-4,15-17$ & 4.15 & 55.2 \\
\hline $310-1-4,40-42$ & 4.40 & 55.5 \\
\hline $310-1-4,59-61$ & 4.59 & 60.3 \\
\hline $310-1-4,87-89$ & 4.87 & 76.9 \\
\hline $310-2-1,54-56$ & 5.54 & 48.9 \\
\hline $310-2-1,80-82$ & 5.80 & 50.5 \\
\hline $310-2-1,111-113$ & 6.11 & 50.5 \\
\hline $310-2-1,143-145$ & 6.43 & 61.5 \\
\hline $310-2-2,6-8$ & 6.56 & 62.5 \\
\hline $310-2-2,38-40$ & 6.88 & 54.6 \\
\hline $310-2-2,72-74$ & 7.22 & 61.7 \\
\hline $310-2-2,101-103$ & 7.51 & 53.9 \\
\hline $310-2-2,119-121$ & 7.69 & 51.0 \\
\hline $310-2-2,140-142$ & 7.90 & 53.2 \\
\hline $310-2-3,11-13$ & 8.11 & 84.4 \\
\hline $310-2-3,36-38$ & 8.36 & 88.1 \\
\hline $310-2-3,56-58$ & 8.56 & 90.5 \\
\hline $310-2-3,82-84$ & 8.82 & 70.2 \\
\hline $310-2-3,107-109$ & 9.07 & 70.0 \\
\hline $310-2-3,139-141$ & 9.39 & 82.9 \\
\hline $310-2-4,6-8$ & 9.56 & 90.0 \\
\hline $310-2-4,23-25$ & 9.73 & 90.6 \\
\hline $310-2-4,34-36$ & 9.84 & 57.9 \\
\hline $310-2-4,56-58$ & 10.06 & 73.6 \\
\hline $310-2-4,94-96$ & 10.44 & 58.7 \\
\hline $310-2-4,120-122$ & 10.70 & 85.7 \\
\hline $310-2-4,136-138$ & 10.86 & 88.9 \\
\hline $310-3-1,4-6$ & 14.54 & 74.4 \\
\hline $310-3-1,30-32$ & 14.80 & 64.2 \\
\hline $310-3-1,59-61$ & 15.09 & 66.5 \\
\hline $310-3-1,88-90$ & 15.38 & 56.5 \\
\hline $310-3-1,125-127$ & 15.75 & 77.3 \\
\hline $310-3-1,147-149$ & 15.97 & 82.6 \\
\hline $310-3-2,1-3$ & 16.01 & 81.1 \\
\hline $310-3-2,30-32$ & 16.30 & 72.4 \\
\hline $310-3-2,54-56$ & 16.54 & 76.7 \\
\hline $310-3-2,79-81$ & 16.79 & 60.2 \\
\hline $310-3-2,107-109$ & 17.07 & 83.7 \\
\hline $310-3-2,138-140$ & 17.38 & 47.7 \\
\hline $310-3-3,2-4$ & 17.52 & 48.4 \\
\hline $310-3-3,30-32$ & 17.80 & 84.1 \\
\hline $310-3-3,54-56$ & 18.04 & 37.0 \\
\hline $310-3-3,80-84$ & 18.30 & 74.3 \\
\hline $310-3-3,96-98$ & 18.46 & 86.9 \\
\hline $310-3-3,126-128$ & 18.76 & 52.7 \\
\hline $310-3-3,147-149$ & 18.96 & 86.6 \\
\hline $310-3-4,2-4$ & 19.02 & 78.8 \\
\hline $310-3-4,32-34$ & 19.32 & 79.4 \\
\hline $310-3-4,56-58$ & 19.56 & 87.7 \\
\hline $310-3-4,69-71$ & 19.69 & 78.1 \\
\hline $310-3-4,87-89$ & 19.87 & 84.6 \\
\hline
\end{tabular}

Table 3. (Continued).

\begin{tabular}{|c|c|c|}
\hline $\begin{array}{c}\text { Sample } \\
\text { (interval in cm) }\end{array}$ & $\begin{array}{l}\text { Sub-bottom } \\
\text { Depth } \\
\text { (m) }\end{array}$ & $\underset{(\%)}{\mathrm{CaCO}_{3}}$ \\
\hline $310-3-4,110-112$ & 20.10 & 60.1 \\
\hline $310-3-4,143-145$ & 20.43 & 76.5 \\
\hline $310-3-5,5-7$ & 20.55 & 71.4 \\
\hline $310-3-5,41-43$ & 20.91 & 82.3 \\
\hline $310-3-5,72-74$ & 21.22 & 86.7 \\
\hline $310-3-5,93-95$ & 21.43 & 90.0 \\
\hline $310-3-5,117-119$ & 21.67 & 74.9 \\
\hline $310-3-5,141-143$ & 21.91 & 53.7 \\
\hline $310-3-6,18-20$ & 22.18 & 61.1 \\
\hline $310-3-6,44-46$ & 22.44 & 93.1 \\
\hline $310-3-6,68-70$ & 22.68 & 86.4 \\
\hline $310-3-6,91-93$ & 22.91 & 61.4 \\
\hline $310-3-6,105-107$ & 23.05 & 91.7 \\
\hline $310-3-6,146-148$ & 23.46 & 66.2 \\
\hline $310-4-1,61-63$ & 24.61 & 84.6 \\
\hline $310-4-1,91-93$ & 24.91 & 74.8 \\
\hline $310-4-1,117-119$ & 25.17 & 89.1 \\
\hline $310-4-1,146-148$ & 25.46 & 90.8 \\
\hline $310-4-2,6-8$ & 25.56 & 91.1 \\
\hline $310-4-2,34-36$ & 25.84 & 59.6 \\
\hline $310-4-2,64-66$ & 26.14 & 82.7 \\
\hline $310-4-2,97-99$ & 26.47 & 70.5 \\
\hline $310-4-2,118-120$ & 26.68 & 77.8 \\
\hline $310-4-2,147-149$ & 26.97 & 73.9 \\
\hline $310-4-3,6-8$ & 27.06 & 72.2 \\
\hline $310-4-3,36-38$ & 27.36 & 62.3 \\
\hline $310-4-3,59-61$ & 27.59 & 79.8 \\
\hline $310-4-3,89-91$ & 27.89 & 76.0 \\
\hline $310-4-3,118-120$ & 28.18 & 67.9 \\
\hline $310-4-3,147-149$ & 28.47 & 87.3 \\
\hline $310-4-4,18-20$ & 28.68 & 61.8 \\
\hline $310-4-4,43-45$ & 28.93 & 75.6 \\
\hline $310-4-4,74-76$ & 29.24 & 86.0 \\
\hline $310-4-4,110-112$ & 29.60 & 50.1 \\
\hline $310-4-4,143-144$ & 29.93 & 62.8 \\
\hline $310-4-5,7-9$ & 30.07 & 66.9 \\
\hline $310-4-5,30-32$ & 30.30 & 63.1 \\
\hline $310-4-5,65-67$ & 30.65 & 87.5 \\
\hline $310-4-5,89-91$ & 30.89 & 85.6 \\
\hline $310-4-5,118-120$ & 31.18 & 84.6 \\
\hline $310-4-5,141-143$ & 31.41 & 75.4 \\
\hline $310-4-6,4-6$ & 31.54 & 80.0 \\
\hline $310-4-6,31-33$ & 31.81 & 80.1 \\
\hline $310-4-6,60-62$ & 32.10 & 67.0 \\
\hline $310-4-6,90-92$ & 32.40 & 72.0 \\
\hline $310-4-6,122-124$ & 32.72 & 79.9 \\
\hline $310-4-6,145-147$ & 32.95 & 82.1 \\
\hline $310-5-1,12-14$ & 33.62 & 64.0 \\
\hline $310-5-1,30-32$ & 33.80 & 89.7 \\
\hline $310-5-1,62-64$ & 34.12 & 82.8 \\
\hline $310-5-1,88-90$ & 34.38 & 90.5 \\
\hline $310-5-1,113-115$ & 34.63 & 87.7 \\
\hline $310-5-1,145-147$ & 34.95 & 85.7 \\
\hline $310-5-2,14-16$ & 35.14 & 80.8 \\
\hline $310-5-2,44-46$ & 35.44 & 86.2 \\
\hline $310-5-2,75-77$ & 35.75 & 89.6 \\
\hline $310-5-2,107-109$ & 36.07 & 89.5 \\
\hline $310-5-2,139-141$ & 36.39 & 74.0 \\
\hline $310-5-3,13-15$ & 36.63 & 82.8 \\
\hline $310-5-3,42-44$ & 36.92 & 90.3 \\
\hline $310-5-3,74-76$ & 37.24 & 90.7 \\
\hline $310-5-3,103-105$ & 37.53 & 90.5 \\
\hline $310-5-3,139-141$ & 37.89 & 88.6 \\
\hline $310-5-4,14-16$ & 38.14 & 85.7 \\
\hline $310-5-4,44-46$ & 38.44 & 78.5 \\
\hline $310-5-4,76-78$ & 38.76 & 82.8 \\
\hline $310-5-4,107-109$ & 39.07 & 73.4 \\
\hline
\end{tabular}


Table 3. (Continued).

\begin{tabular}{|c|c|c|}
\hline $\begin{array}{c}\text { Sample } \\
\text { (interval in } \mathrm{cm} \text { ) }\end{array}$ & $\begin{array}{l}\text { Sub-bottom } \\
\text { Depth } \\
\text { (m) }\end{array}$ & $\begin{array}{c}\mathrm{CaCO}_{3} \\
(\%)\end{array}$ \\
\hline $310-5-4,135-137$ & 39.35 & 84.1 \\
\hline $310-5-5,11-13$ & 39.61 & 90.3 \\
\hline $310-5-5,41-43$ & 39.91 & 89.9 \\
\hline $310-5-5,74-76$ & 40.24 & 89.6 \\
\hline $310-5-5,105-107$ & 40.55 & 86.7 \\
\hline $310-5-5,134-136$ & 40.84 & 79.4 \\
\hline $310-5-6,11-13$ & 41.11 & 89.4 \\
\hline $310-5-6,41-43$ & 41.41 & 82.8 \\
\hline $310-5-6,68-70$ & 41.68 & 81.4 \\
\hline $310-5-6,102-104$ & 42.02 & 91.6 \\
\hline $310-5-6,132-134$ & 42.32 & 69.6 \\
\hline $310-6-1,53-55$ & 43.53 & 81.5 \\
\hline $310-6-1,79-81$ & 43.79 & 89.6 \\
\hline $310-6-1,102-104$ & 44.02 & 89.0 \\
\hline $310-6-1,143-144$ & 44.43 & 90.7 \\
\hline $310-6-2,12-14$ & 44.62 & 92.7 \\
\hline $310-6-2,42-44$ & 44.92 & 87.9 \\
\hline $310-6-2,74-76$ & 45.24 & 88.6 \\
\hline $310-6-2,105-107$ & 45.55 & 93.2 \\
\hline $310-6-2,135-137$ & 45.85 & 89.2 \\
\hline $310-6-3,11-13$ & 46.11 & 86.8 \\
\hline $310-6-3,43-45$ & 46.43 & 87.4 \\
\hline $310-6-3,69-71$ & 46.69 & 64.4 \\
\hline $310-6-3,102-104$ & 47.02 & 71.2 \\
\hline $310-6-3,133-135$ & 47.33 & 62.6 \\
\hline $310-6-4,14-16$ & 47.64 & 53.6 \\
\hline $310-6-4,44-46$ & 47.94 & 88.3 \\
\hline $310-6-4,75-77$ & 48.25 & 83.7 \\
\hline $310-6-4,87-89$ & 48.37 & 63.2 \\
\hline $310-6-4,114-116$ & 48.64 & 86.2 \\
\hline $310-6-4,145-147$ & 48.95 & 84.8 \\
\hline $310-6-5,10-12$ & 49.10 & 90.7 \\
\hline $310-6-5,38-40$ & 49.38 & 80.6 \\
\hline $310-6-5,67-69$ & 49.67 & 78.4 \\
\hline $310-6-5,97-99$ & 49.97 & 72.4 \\
\hline $310-6-5,132-134$ & 50.32 & 45.7 \\
\hline $310-6-6,16-18$ & 50.66 & 74.8 \\
\hline $310-6-6,47-49$ & 50.97 & 87.2 \\
\hline $310-6-6,77-79$ & 51.27 & 88.3 \\
\hline $310-6-6,109-111$ & 51.59 & 85.7 \\
\hline $310-6-6,137-139$ & 51.87 & 86.7 \\
\hline $310-7-1,97-99$ & 53.47 & 83.8 \\
\hline $310-7-1,113-115$ & 53.63 & 65.2 \\
\hline $310-7-1,128-130$ & 53.78 & 43.7 \\
\hline $310-7-1,146-148$ & 53.96 & 87.0 \\
\hline $310-7-2,15-17$ & 54.15 & 60.8 \\
\hline $310-7-2,42-44$ & 54.42 & 73.6 \\
\hline $310-7-2,69-71$ & 54.69 & 82.1 \\
\hline $310-7-2,97-99$ & 54.97 & 76.9 \\
\hline $310-7-2,129-131$ & 55.29 & 67.1 \\
\hline $310-7-3,12-14$ & 55.62 & 87.7 \\
\hline $310-7-3,42-44$ & 55.92 & 68.6 \\
\hline $310-7-3,66-68$ & 56.16 & 80.9 \\
\hline $310-7-3,90-92$ & 56.40 & 87.6 \\
\hline $310-7-3,115-117$ & 56.65 & 66.9 \\
\hline $310-7-3,140-142$ & 56.90 & 60.6 \\
\hline $310-7-4,17-18$ & 57.17 & 44.5 \\
\hline $310-7-4,45-47$ & 57.45 & 72.2 \\
\hline $310-7-4,78-80$ & 57.78 & 50.9 \\
\hline $310-7-4,108-110$ & 58.08 & 54.4 \\
\hline $310-7-4,140-142$ & 58.40 & 84.8 \\
\hline $310-7-5,8-10$ & 58.58 & 74.5 \\
\hline $310-7-5,41-43$ & 58.91 & 75.4 \\
\hline $310-7-5,72-74$ & 59.22 & 77.1 \\
\hline $310-7-5,100-102$ & 59.50 & 77.5 \\
\hline $310-7-5,133-135$ & 59.83 & 72.4 \\
\hline $310-8-1,15-17$ & 62.15 & 77.9 \\
\hline $310-8-1,46-48$ & 62.46 & 87.1 \\
\hline
\end{tabular}

Table 3. (Continued).

\begin{tabular}{lcc}
\hline \multicolumn{1}{c}{ Sample } & $\begin{array}{c}\text { Sub-bottom } \\
\text { Depth }\end{array}$ & $\begin{array}{c}\text { CaCO } \\
\text { (m) }\end{array}$ \\
(interval in cm) & $(\%)$ \\
\hline $310-8-1,77-79$ & 62.77 & 64.6 \\
$310-8-1,110-112$ & 63.10 & 68.1 \\
$310-8-1,139-141$ & 63.39 & 73.5 \\
$310-8-2,13-15$ & 63.63 & 77.1 \\
$310-8-2,43-45$ & 63.93 & 80.7 \\
$310-8-2,74-76$ & 64.24 & 73.3 \\
$310-8-2,106-108$ & 64.56 & 83.7 \\
$310-8-2,136-138$ & 64.86 & 79.6 \\
$310-8-3,15-17$ & 65.15 & 50.3 \\
$310-8-3,46-48$ & 65.46 & 36.8 \\
$310-8-3,76-78$ & 65.76 & 50.5 \\
$310-8-3,107-109$ & 66.07 & 51.9 \\
$310-8-3,141-143$ & 66.41 & 82.1 \\
$310-8-4,13-15$ & 66.63 & 74.0 \\
$310-8-4,41-43$ & 66.91 & 85.1 \\
$310-8-4,68-70$ & 67.18 & 79.1 \\
$310-8-4,101-103$ & 67.51 & 85.4 \\
$310-8-4,131-133$ & 67.81 & 79.2 \\
$310-8-5,10-12$ & 68.10 & 91.4 \\
$310-8-5,40-42$ & 68.40 & 71.0 \\
$310-8-5,74-76$ & 68.74 & 79.7 \\
$310-8-5,103-105$ & 69.03 & 44.0 \\
$310-8-5,131-133$ & 69.31 & 55.1 \\
$310-8-6,7-9$ & 69.57 & 84.0 \\
$310-8-6,35-37$ & 69.85 & 70.4 \\
$310-8-6,65-67$ & 70.15 & 66.9 \\
$310-8-6,97-99$ & 70.47 & 67.9 \\
$310-8-6,130-132$ & 71.20 & 68.4 \\
$310-9-1,12-14$ & 71.62 & 88.8 \\
$310-9-1,41-43$ & 71.91 & 91.8 \\
$310-9-1,73-75$ & 72.23 & 91.0 \\
$310-9-1,103-105$ & 72.53 & 89.5 \\
$310-9-1,136-138$ & 72.86 & 84.4 \\
$310-9-2,13-15$ & 73.13 & 83.4 \\
$310-9-2,43-45$ & 73.43 & 74.4 \\
$310-9-2,73-75$ & 73.73 & 78.1 \\
$310-9-2,104-106$ & 74.04 & 74.4 \\
$310-9-2,136-138$ & 74.36 & 76.9 \\
$310-9-3,13-15$ & 74.63 & 76.5 \\
$310-9-3,45-47$ & 74.95 & 63.9 \\
$310-9-3,76-78$ & 75.26 & 72.5 \\
$310-9-3,108-110$ & 75.58 & 71.2 \\
$310-9-3,143-145$ & 75.93 & 68.2 \\
$310-9-4,13-15$ & 76.13 & 61.0 \\
$310-9-4,43-45$ & 76.43 & 75.9 \\
$310-9-4,74-76$ & 76.74 & 82.7 \\
$310-9-4,103-105$ & 77.03 & 87.1 \\
$310-9-4,132-134$ & 77.32 & 89.7 \\
$310-9-5,13-15$ & 77.63 & 86.0 \\
$310-9-5,43-45$ & 77.93 & 87.4 \\
$310-9-5,73-75$ & 78.23 & 76.7 \\
$310-9-5,100-102$ & 78.50 & 83.3 \\
$310-9-5,130-132$ & 78.80 & 76.2 \\
$310-9-6,18-20$ & 79.18 & 33.7 \\
$310-9-6,40-42$ & 79.40 & 93.3 \\
$310-9-6,68-70$ & 79.68 & 80.9 \\
$310-9-6,102-104$ & 80.02 & 79.9 \\
$310-9-6,132-134$ & 80.32 & 74.3 \\
\hline & & \\
\hline
\end{tabular}

through biostratigraphic correlations based on paleomagnetically dated paleontological events. Carbonate events identified at Site $\mathbf{3 1 0}$ are listed in Table 13.

\section{Pleistocene Correlations}

The recognition of the Pliocene/Pleistocene boundary in deep-sea sediments poses some difficulties which 


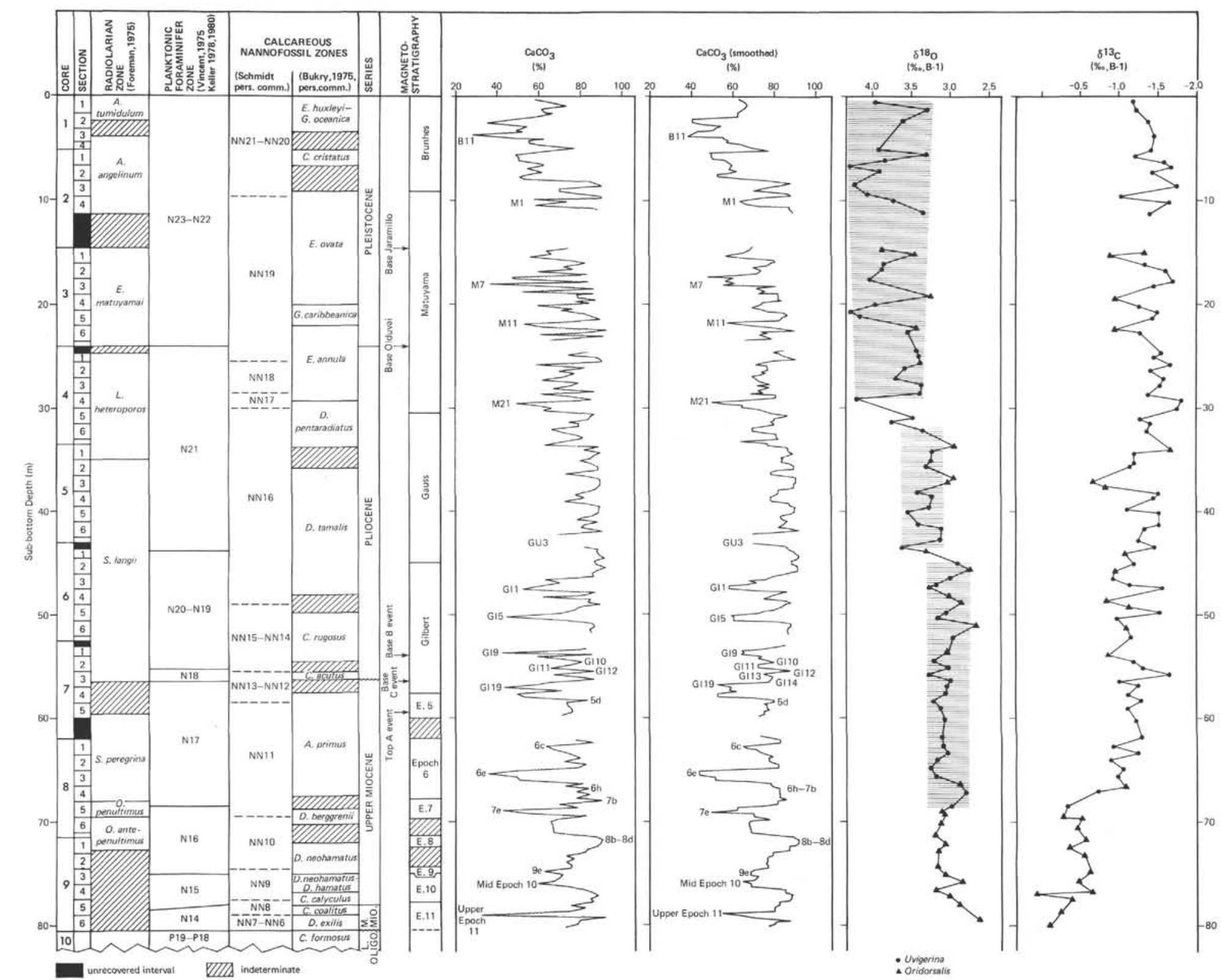

Figure 2. Neogene biostratigraphy, magnetostratigraphy, carbonate stratigraphy, and isotope stratigraphy at DSDP Site 310. Magnetostratigraphy derived from correlation with paleomagnetically dated cores (see text). $\mathrm{CaCO}_{3}$ data from Table 3 (smoothed curve: three points running average). Isotopic data from Keigwin (1979) for benthic foraminifers expressed in per mill, $\mathrm{B}-1$ (which may be converted to PDB by subtracting $0.06 \%$ from $\delta^{18} \mathrm{O}$ and adding $0.64 \%$ to $\delta^{13} \mathrm{C}$ ); dots: Uvigerina; triangles: Oridorsalis. (Oridorsalis $\delta^{13} \mathrm{C}$ data were "converted" to Uvigerina values by adding $0.56 \%$ ). The envelope of the $\delta^{18} \mathrm{O}$ curve (shaded) emphasizes the different regimes in ${ }^{18} \mathrm{O}$ fluctuations in the late Neogene separated by two distinct steps in the ${ }^{18} \mathrm{O}$ enrichment trend. Note the coincidence of low-carbonate event M21 with the ${ }^{18} \mathrm{O}$ step just above the Gauss/Matuyama boundary. 


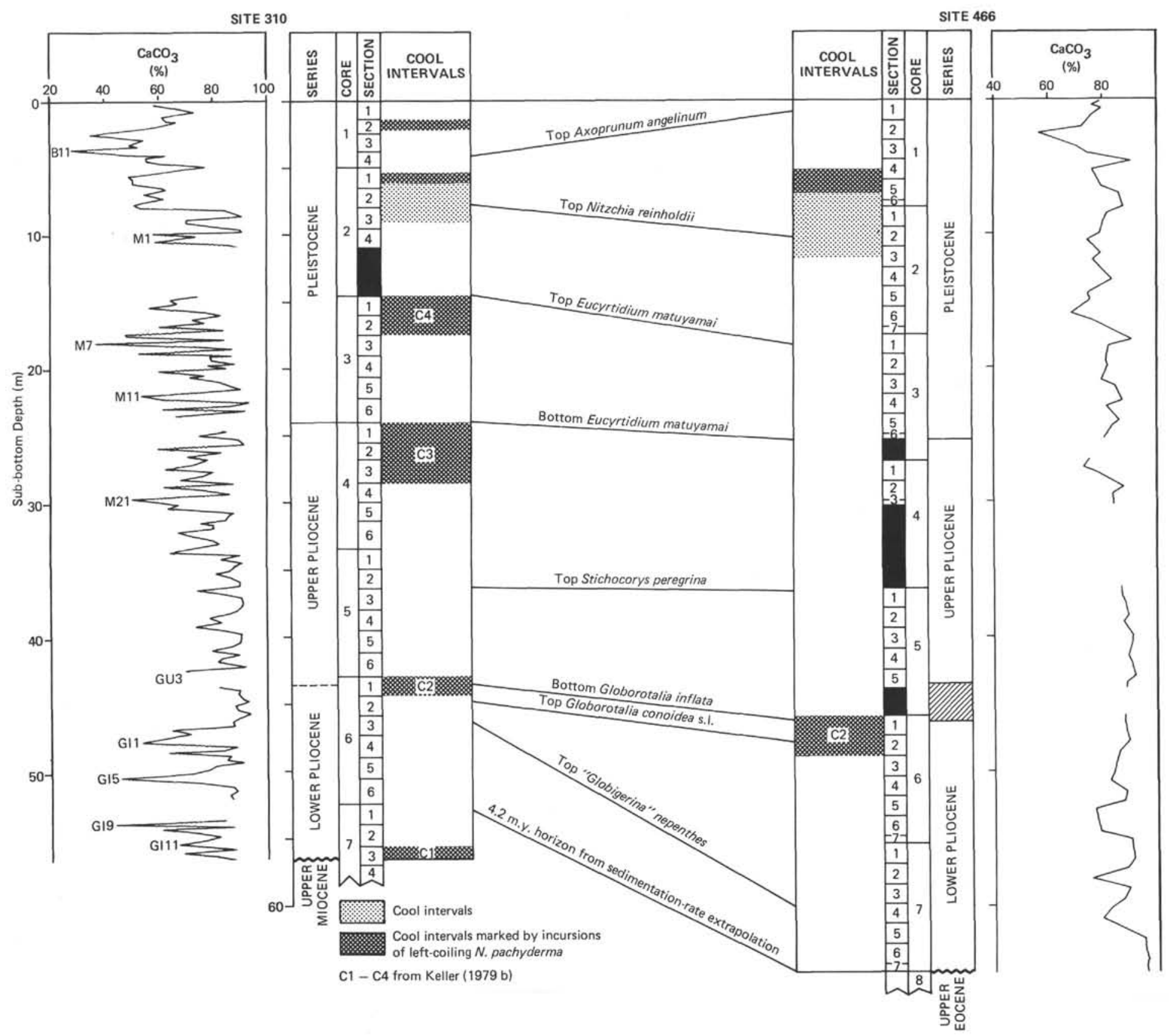




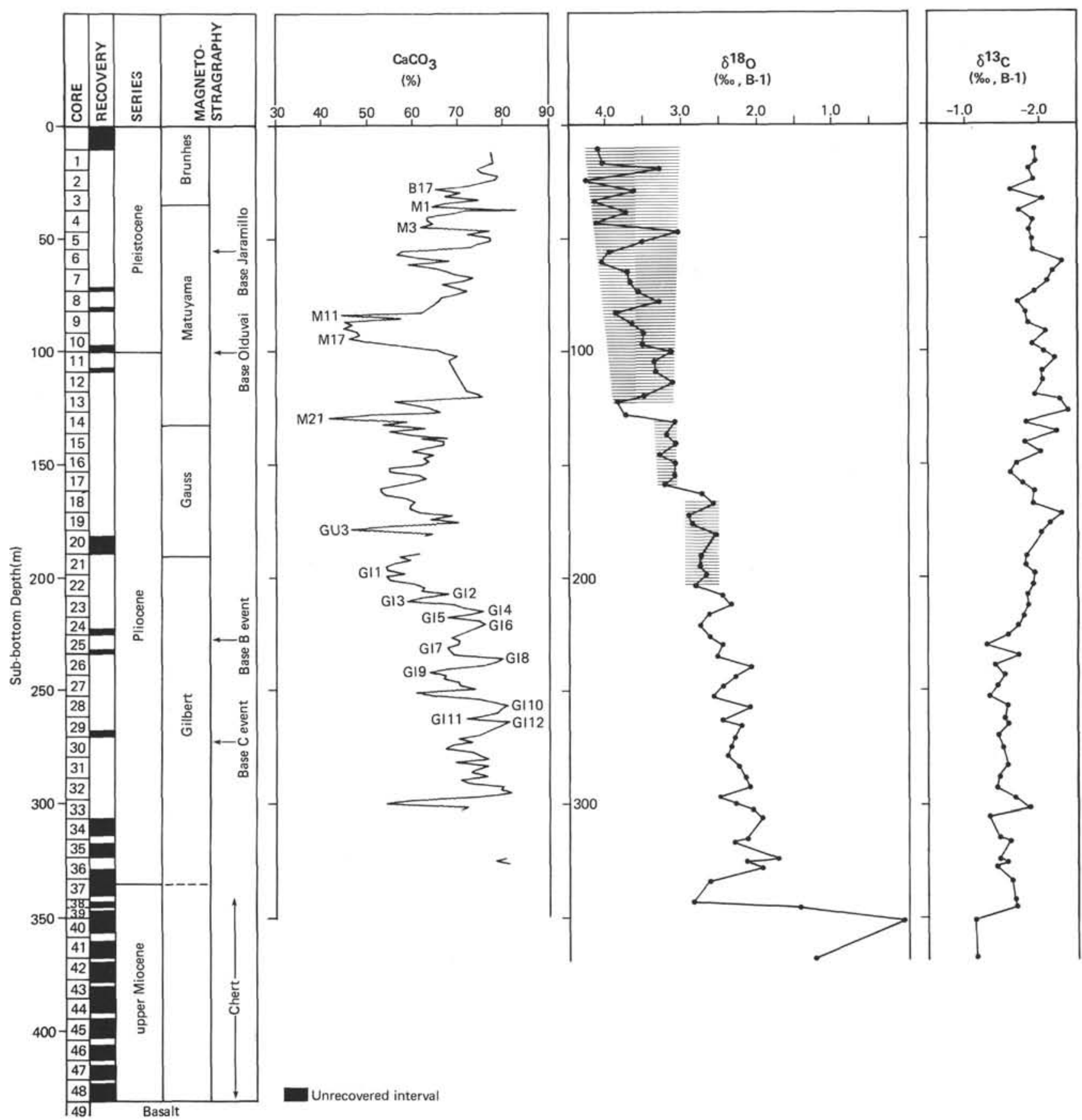

Figure 4. Magnetostratigraphy, carbonate stratigraphy, and isotope stratigraphy at DSDP Site 157. Magnetostratigraphy derived from correlations with paleomagnetically dated cores (see text, and Kaneps, $1973 \mathrm{~b}, \mathrm{CaCO}_{3}$ data from Bode and Cronan (1973). Isotopic data from Keigwin (1979) for Uvigerina. Note the coincidence, as at Site 310, of low-carbonate event M21 with the enrichment in ${ }^{18} \mathrm{O}$ just above the Gauss/Matuyama boundary.

are not necessarily a hindrance to biostratigraphic correlations between various sequences.

The Plio/Pleistocene boundary defined at its Sicilian stratotype has been correlated into deep-sea sediments to a level equivalent to, or slightly younger than, the top of the Olduvai normal paleomagnetic event, being thus dated at approximately 1.6 m.y. (Haq et al., 1977). A number of paleontological events have been shown to be closely associated with the Olduvai in paleomagnetically dated deep-sea cores. These events include the FADs of Globorotalia truncatulinoides, Pseudoeunotia doliolus and Eucyrtidium matuyamai, and the LADs of Discoaster brouweri and Pterocanium prismatium (Table 12). The stratigraphic positions of these paleontological datum levels relative to the Olduvai varies from near the top to near the base of this paleomagnetic event and thus are not exactly time-equivalent. Their stratigraphic spacing within a section, however, is often within the 


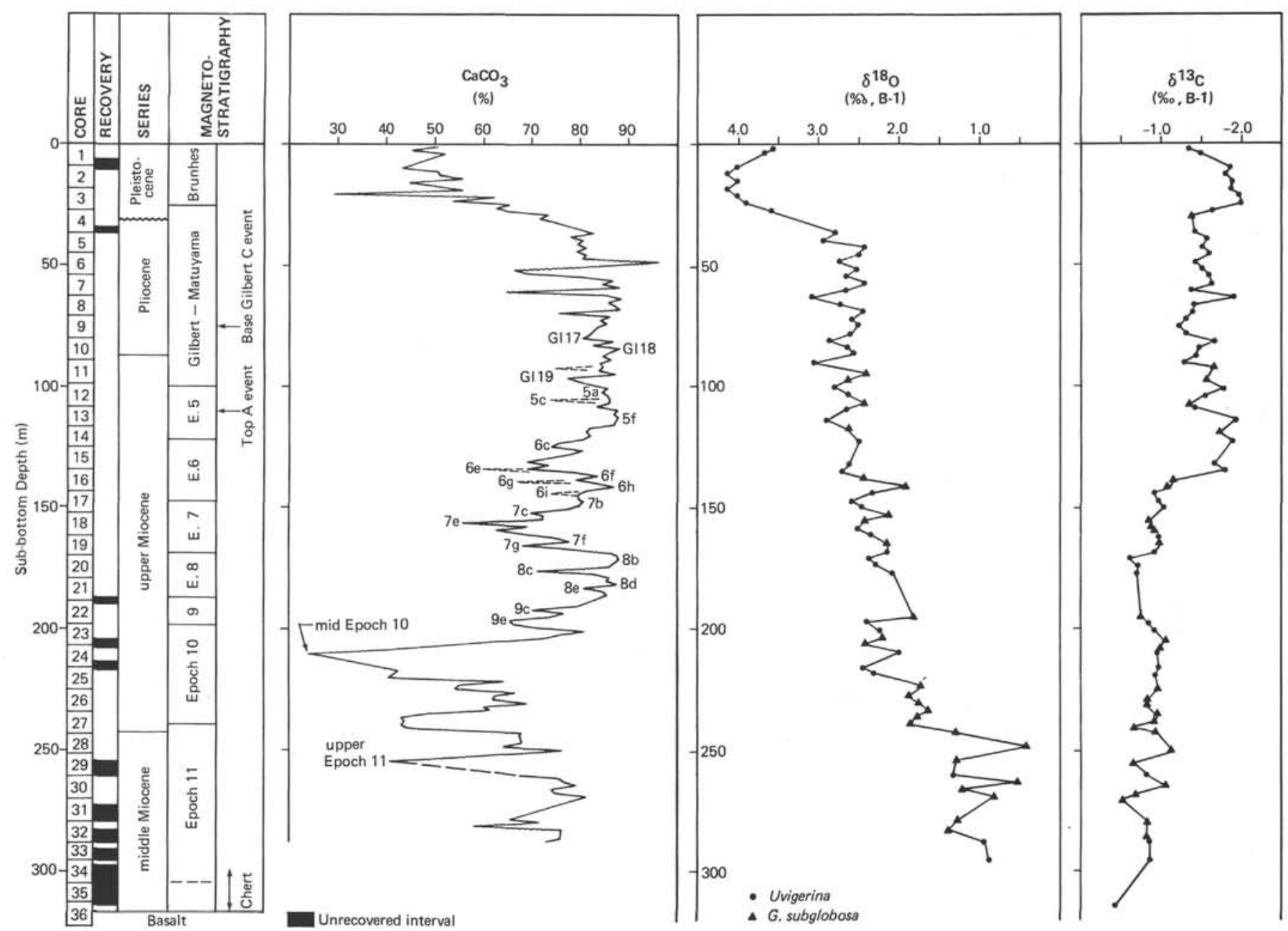

Figure 5. Magnetostratigraphy, carbonate stratigraphy, and isotope stratigraphy at DSDP Site 158. Magnetostratigraphy derived from correlations with paleomagnetically dated cores (see text). $\mathrm{CaCO}_{3}$ data from Bode and Cronan (1973) for the solid curve and Dunn and Moore (1981) for the dashed curve. Isotopic data from Keigwin (1979) for benthic foraminifers; dots: Uvigerina; triangles: Globocassidulina subglobosa (G. subglobosa $\delta^{13} \mathrm{C}$ data were "converted" to Uvigerina value by subtracting $0.16 \%$ ).

range of biostratigraphic resolution, especially in drilled sediments; for convenience they often have been used as criteria for placing the Plio/Pleistocene boundary.

At Site 310, P. doliolus, E. matuyamai, and G. truncatulinoides first occur simultaneously at the base of Core 3. The Plio/Pleistocene boundary is therefore placed at this level. The last occurrence of $D$. brouweri is found lower in the section, in the middle of Core 4, and thus is not a reliable chronostratigraphic marker at this site. In the equatorial cores, however, D. brouweri last occurs within the Olduvai, slightly below the LAD of $P$. prismatium; the latter tropical radiolarian species is not present at mid-latitude Site 310 , whereas the temperate species E. matuyamai, present at Site 310 , does not occur in the equatorial cores. The temperate planktonic foraminifer $G$. truncatulinoides is rare in tropical areas, and its first occurrence is not a reliable marker there; it is commonly found significantly above the Olduvai event (see Tables 4-7). It thus appears that, with the exception of the FAD of $P$. doliolus, no firstorder correlation is possible between the paleontological events present at mid-latitude Site 310 near the Plio-
cene/Pleistocene boundary and those occurring in equatorial cores. Second-order correlation through paleomagnetostratigraphy, however, permits us to place with confidence the Olduvai event at Site 310 in the lowermost part of Core 3 to the uppermost part of Core 4 .

Carbonate minimum M17 is associated with the Olduvai event in equatorial cores. This minimum possibly is present at Site 310 in the unrecovered interval at the top of Core 4, between 23.5 and 24.6 meters. The carbonate content of $66.2 \%$ in Sample 3-6, 146-148 cm (23.5 m)significantly lower than the values of 91.7 and $84.6 \%$ in the two adjacent samples-supports the assumption of a decreasing trend in carbonate content in the unrecovered interval.

Among the Pleistocene biostratigraphic datums, the LAD of Axoprunum angelinum is present at all sites. In the tropical sections of Cores RC11-209 and V24-58, it is distinctly associated with carbonate maximum B10. Thus, it is possible to assume that this carbonate maximum is represented at Site 310 at 2.8 meters. The most pronounced of the lower Brunhes carbonate minima, B11, would then occur at 3.6 meters. 


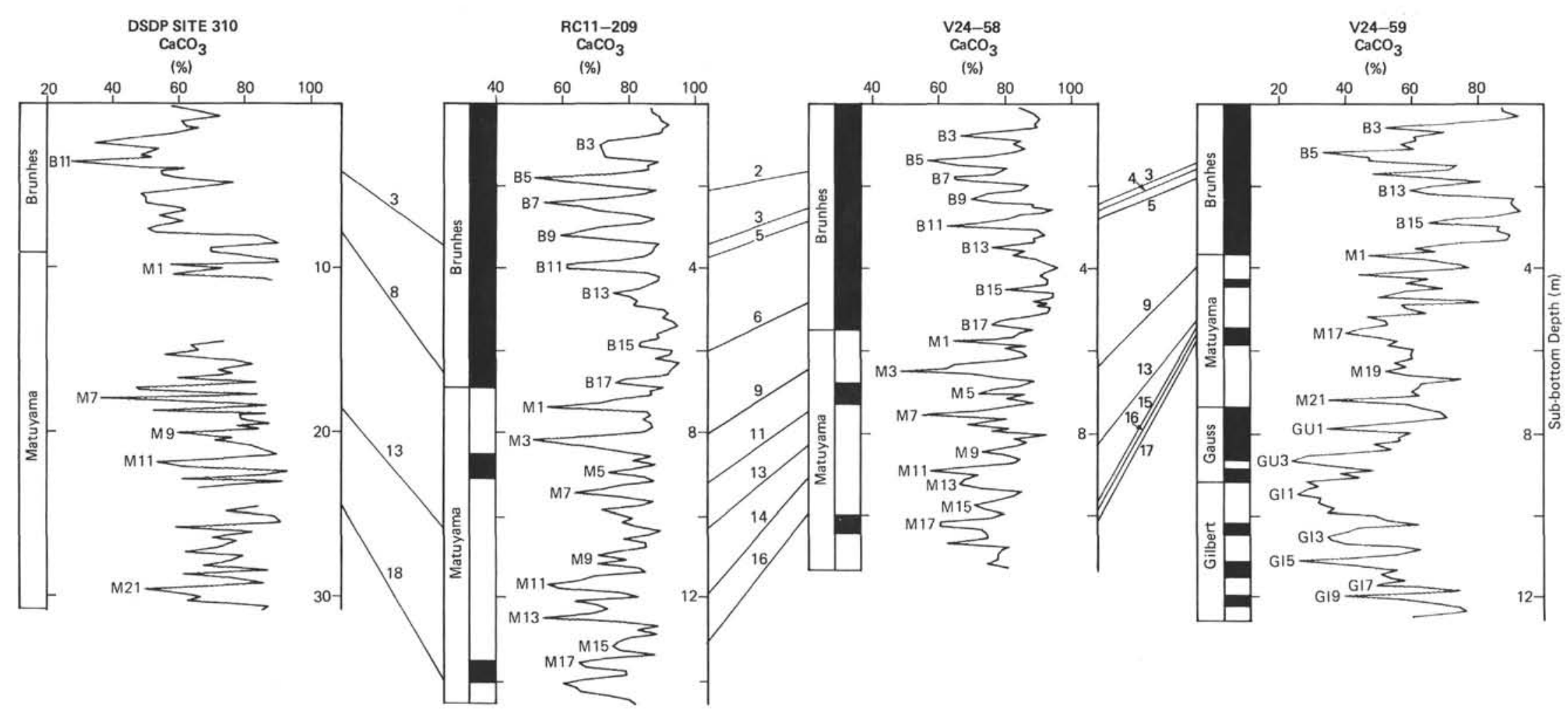

Biostratigraphic Correlations (numbers follow listing in Table 12; $T=$ top; $B=$ bottom):
2 Collosphaera sp. A $\rightarrow$ Buccinosphaera invaginata 11 T Anthocyrtidium angulare
3 T Axoprunum angelinum
13 B Mesocena elliptica,$T$, trachelium
Pseudoemiliania lacuno
Collosphaera tuber
15 T Rhizosolenia praebergoni
$\begin{array}{lll}8 & \text { T } & \text { Nitzschia reinholdi } \\ 9 & \text { T } & \text { Mesocena eliptica }\end{array}$
18 B Pseudoeunotia doliolus.

Figure 6. Correlations of Pleistocene carbonate stratigraphies between DSDP Site 310 (Hess Rise) and equatorial piston cores. Biostratigraphic correlations based on data from Tables 4, 5,6 , and 11 . Numbers on the right-hand side of each sequence refer to sub-bottom depths in meters. 
Two siliceous-fossil events, the LADs of Nitzschia reinholdii and of Mesocena elliptica, bracket the base of the Brunhes in the equatorial Pacific (Tables 4 and 7), as well as at mid-latitudes of the northeast Pacific (Burckle and Opdyke, 1977) and of the North Atlantic (Burckle, 1979). The former event occurs in RC11-209 in carbonate maximum B16, and the latter occurs in both Cores RC11-209 and V24-58 within the transition from carbonate maximum $\mathrm{M} 2$ to carbonate minimum M3. These two paleontological events thus bracket carbonate event M1. The last occurrences of $N$. reinholdii and of $M$. elliptica were both found at Site 310 in Core 2, Section 2 . The exact position of these two levels cannot be defined, because of a large sampling interval. Their cooccurrence, however, indicates that the last $M$. elliptica is probably slightly too high in the section. Carbonate minimum M1 thus cannot be identified with confidence, but it possibly corresponds to the carbonate minimum at 10 meters; if this assumption is correct, the base of the Brunhes at Site 310 would be located at approximately 9 meters, an inference in agreement with the sedimentation-rate curve (Vincent, this volume).

The radiolarian species Anthocyrtidium angulare last appears in the equatorial Cores RC11-209 and V24-58 just below the base of the Jaramillo. This tropical species, however, cannot be used as a marker at mid-latitude Site 310. At the latter site, the base of the Jaramillo can be equated to the LAD of E. matuyamai, which in the North Pacific has been shown to coincide with this paleomagnetic event (Hays, 1970). E. matuyamai last occurs at Site 310 in Sample 2,CC, which is here arbitrarily placed at 14.5 meters, the nominal depth of the base of Core 2. A wide unrecovered interval in the lower part of this core, however, precludes accurate placement of Sample 2,CC.

The FAD of $M$. elliptica in the reversed interval between the Olduvai and the Jaramillo occurs in an interval of carbonate maximum (M8) in both Cores RC11209 and V24-58. M. elliptica first occurs in Site 310 in the middle of Core 3 . Thus, it is probable that the pronounced carbonate minimum M7, bracketed by the base of the Jaramillo and the FAD of M. ellipitica in both Cores RC11-209 and V24-58, is represented at Site 310 by the low-carbonate peak centered at 18 meters. If this assumption is correct, M11-which is the most pronounced carbonate minimum in the interval between M7 and M17 in RC11-209 and V24-58-at Site 310 would be represented by the low-carbonate peak centered at 21.9 meters, and the less-pronounced carbonate minimum M9 would be at 20.1 meters.

\section{Pliocene Correlations}

Thalassiosira convexa last occurs in both Cores V2459 and RC12-66 in the lower Matuyama, within carbonate maximum M20, whereas Nitzschia jouseae last occurs slightly lower in Core RC12-66, in the uppermost carbonate maximum of the Gauss. These two diatom events occur at Site 310 in Core 4. Their exact stratigraphic position cannot be defined, because of a large sampling interval. It is nevertheless highly probable that the distinct, pronounced carbonate minimum of the lowermost Matuyama, M21, bracketed in equatorial Pacific sequences (in piston cores as well as at Site 157) by the FADs of $T$. convexa and $N$. jouseae, is represented at Site 310 by the pronounced low-carbonate peak at 29.6 meters. The base of the Matuyama, which falls just below M21 in the piston cores, thus would be located at about 31 meters at Site 310, in agreement with the sedimentation-rate curve constructed by Vincent (this volume; see her fig. 7).

The very pronounced carbonate minimum of the mid-Pliocene, GU3, is associated in both equatorial sections RC12-66 and DSDP 157 with the FAD of Rhizosolenia praebergonii var. A and is bracketed in both sections, as well as in V24-59, by the FADs of Stichocorys peregrina and Sphaeroidinellopsis spp. The two latter events occur at Site 310 in upper Core 5 and upper Core 6 , respectively. It is probable that the mid-Pliocene minimum GU3 occurs at Site 310 in the unrecovered interval at the top of Core 6 between 42.3 and 43.5 meters. The carbonate content of $69.6 \%$ in Sample 5-6, $132-134 \mathrm{~cm}(42.3 \mathrm{~m})$, directly above the unrecovered interval, is significantly lower than the values of 91.6 and $81.5 \%$ in the two adjacent samples and supports the assumption of a decreasing trend in carbonate content in this interval.

From a detailed diatom study conducted by Burckle (pers. comm.) for Site 310 and Core RC12-66 from the lower Gilbert down to mid-Epoch 6, close biostratigraphic correlations can be drawn between both sequences for this interval. The uppermost diatom level of this interval is the FAD of Nitzschia jouseae, which occurs in RC12-66 in the upper Gilbert $C$ event just below carbonate minimum GI9. Above that level, up to the LAD of Sphaeroidinellopsis spp., the only available paleontological event useful for correlating Site 310 with equatorial sections is the FAD of Lamprocyrtis heteroporos, which occurs at the base of the Gilbert B event in Core V24-59.

Slightly below the FAD of $N$. jouseae is the FAD of Ceratolithus rugosus, which occurs in both RC12-66 and V24-59 within the Gilbert C. This calcareous-nannofossil event occupies the same stratigraphic position in terms of paleomagnetostratigraphy in the North Atlantic (Mazzei et al., 1979), and has been shown to be a reliable chronostratigraphic marker in the Mediterranean as well (Cita and Gartner, 1973; Stradner, 1973; Cita, 1975b).

Kaneps (1973b) pointed out the remarkable identical position of the $C$. rugosus FAD with respect to carbonate stratigraphy within minimum GI11 of the double peak GI10-GI11-GI12 in both RC12-66 and Site 157, as well as at Site 132 in the Mediterranean. He inferred the equivalence of the peaks, assigning them to the carbonate double maximum GI10-GI11-GI12 in the three sequences. At Site 310, the FAD of C. rugosus, at approximately 55 meters, occurs in a similar position in terms of carbonate stratigraphy, slightly below the FAD of $N$. jouseae. It is thus possible to identify at Site 310 the carbonate minimum GI9 at 53.8 meters, bracketed by the FADs of $N$. jouseae and $L$. heteroporos, and at 55.3 


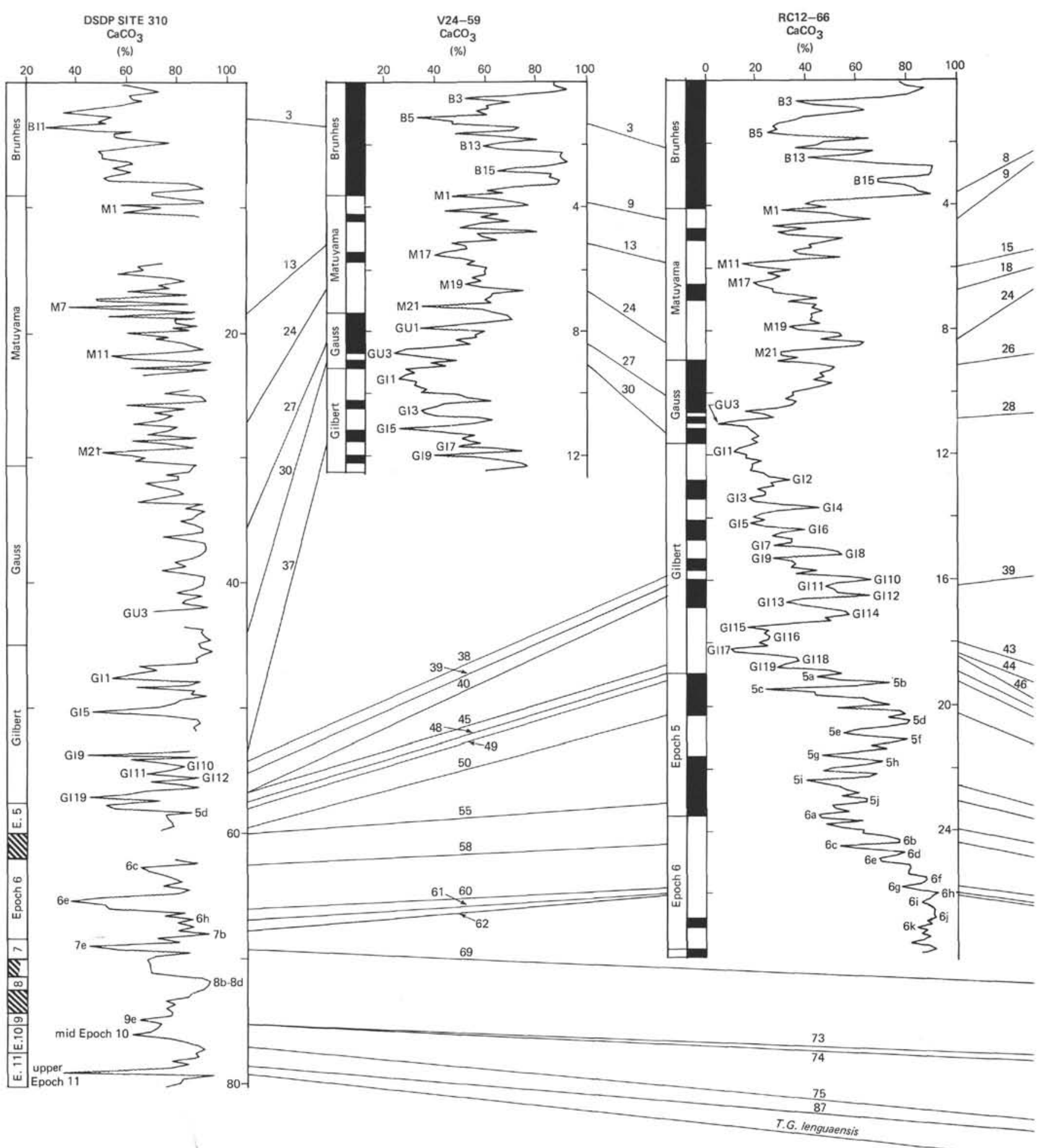

Figure 7. Correlations of Neogene carbonate stratigraphies between DSDP Site 310 (Hess Rise) and equatorial sequences (DSDP Sites 157 and 158 and piston cores V24-59, RC12-66, and RC12-65). Biostratigraphic correlations based on data from Tables 6 through 11. Numbers on the righthand side of each sequence refer to sub-bottom depths in meters. The curves of Site 158 and Core RC12-65 are aligned with that of Core RC12-66 following the Epoch 6/Epoch 7 boundary.

meters the carbonate minimum GI11 within the double carbonate peak GI10-GI11-GI12.

At Site 158, the FADs of $C$. rugosus and $N$. jouseae occur very close to each other near 72 meters. The small carbonate minimum which occurs at this level within a double-peak maximum thus may correspond to GI11. This identification, however, remains tentative, because the condensed state of the Pliocene sequence at this site, with an unconformity, makes difficult the interpretation of the Pliocene carbonate stratigraphy. 


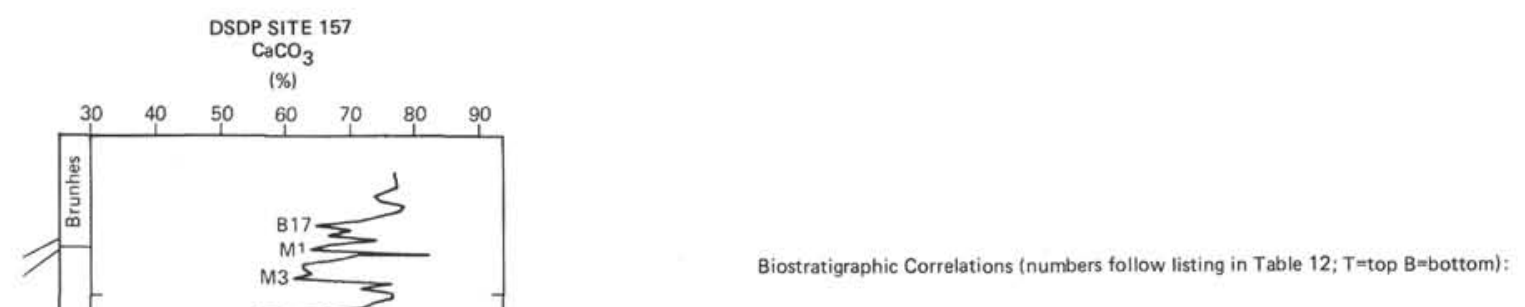

Draphic Correlations (numbers follow listing in Table 12; T=top B=bottom):

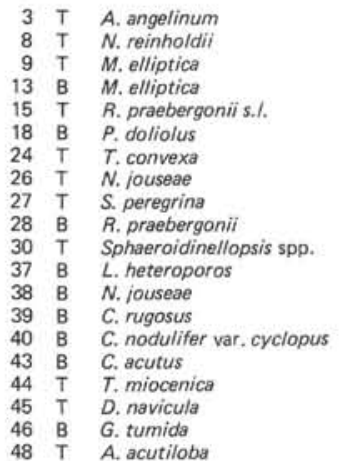

49 B D. navicula

50 T N. miocenica

54 B P.primalis

T T.preaconvexa

T C. praepalacea

B Tracenica

B T.praeconvexa

B N. miocenica var. elongata

61 Epoch 6 Carbon Shift

B S. peregrina

66 T T. burckliana

T . yabei $(=C$, plicatus)

68 B T. burcklian

69 T O. hugesi

73 B N. acostaensis

T D. hamatus

87 B D. hamatus

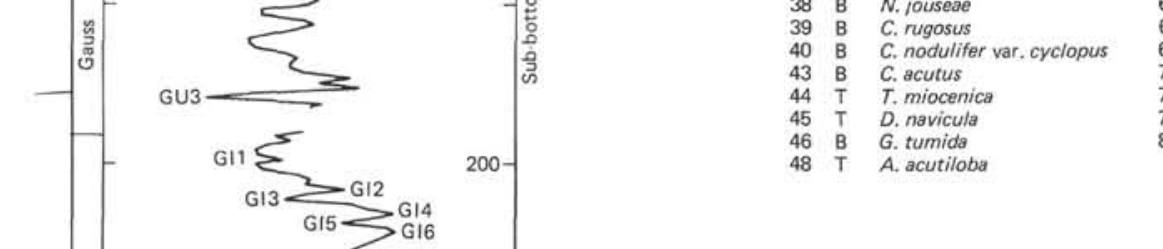


Table 4. Biostratigraphic events in Core RC11-209.

\begin{tabular}{|c|c|c|c|}
\hline & Paleontological Event ${ }^{1}$ & $\begin{array}{l}\text { Depth in Core } \\
(\mathrm{m})^{2}\end{array}$ & References \\
\hline 2 & Collosphaera sp. $\mathrm{A} \rightarrow$ Buccinosphaera invaginata $(\mathrm{R})$ & $2.00-2.30$ & Johnson and Knoll (1975) \\
\hline 3 & $\mathrm{~T}$ Axoprunum angelinum ( $\mathrm{R})$ & $3.20-3.40$ & Johnson and Knoll (1975) \\
\hline 5 & B Collosphaera tuberosa (R) & $3.62-3.80$ & Johnson and Knoll (1975) \\
\hline 6 & B Collosphaera sp. A (R) & $5.98-6.18$ & Johnson and Knoll (1975) \\
\hline 7 & T Globorotalia tosaensis (F) & -6.2 & Thompson and Sciarrillo (1978) \\
\hline 8 & T Nitzschia reinholdii (D) & -6.50 & Burckie (1977) \\
\hline 9 & T Mesocena elliptica (S) & -8.00 & Burckle (1977) \\
\hline 11 & T Anthocyrtidium angulare $(\mathrm{R})$ & $9.20-9.30$ & Johnson and Knoll (1975) \\
\hline 12 & T Lamprocyrtis neoheteroporos $(\mathrm{R})$ & $9.80-10.15$ & Johnson and Knoll (1975) \\
\hline 22 & B Globorotalia truncatulinoides (F) & -10.00 & Thompson and Sciarrillo (1978) \\
\hline 13 & B Mesocena elliptica (S) & -10.20 & Burckle (1977) \\
\hline 14 & Theocorythium vetulum $\rightarrow T$. trachelium $(\mathrm{R})$ & $11.62-12.00$ & Johnson and Knoll (1975) \\
\hline 15 & $\mathrm{~T}$ Rhizosolenia praebergonii (D) & -12.55 & Burckle (1977) \\
\hline 16 & T Pterocanium prismatium ( $\mathrm{R})$ & $12.81-13.21$ & Johnson and Knoll (1975) \\
\hline 18 & B Pseudoeunotia doliolus (D) & -13.90 & Burckle (1977) \\
\hline
\end{tabular}

Table 5. Biostratigraphic events in Core V24-58.*

\begin{tabular}{|c|c|c|c|}
\hline & Paleontological Event & $\begin{array}{l}\text { Depth in Core } \\
\text { (m) }\end{array}$ & References \\
\hline 1 & B Emiliania huxleyi $(\mathbb{N})$ & 0.60 & Gartner (1973) \\
\hline 2 & Collosphaera sp. $\mathrm{A} \rightarrow B$. invaginata $(\mathrm{R})$ & $1.50-1.80$ & Johnson and Knoll (1975) \\
\hline 3 & T Axoprunum angelinum ( $\mathrm{R}$ ) & 2.50 & $\begin{array}{l}\text { Hays et al. (1969), Johnson } \\
\text { and Knoll (1975) }\end{array}$ \\
\hline 4 & T Pseudoemiliania lacunosa $(\mathbb{N})$ & 2.60 & Gartner (1973) \\
\hline 5 & B Collosphaera tuberosa $(\mathrm{R})$ & $2.72-2.97$ & Johnson and Knoll (1975) \\
\hline 6 & B Collosphaera sp. A (R) & $4.76-5.04$ & Johnson and Knoll (1975) \\
\hline 7 & T Globorotalia tosaensis $(\mathrm{F})$ & -5.50 & Thompson and Sciarrillo (1978) \\
\hline 9 & T Mesocena elliptica (S) & $6.40-6.50$ & Hays et al. (1969) \\
\hline 11 & T Anthocyrtidium angulare $(\mathrm{R})$ & $7.30-7.41$ & Johnson and Knoll (1975) \\
\hline 12 & T Lamprocyrtis neoheteroporos ( $\mathrm{R})$ & $7.30-7.53$ & Johnson and Knoll (1975) \\
\hline 13 & B Mesocena elliptica (S) & -8.25 & Hays et al. (1969) \\
\hline 14 & Theocorythium vetulum $\rightarrow T$. trachelium $(\mathrm{R})$ & $8.82-9.28$ & Johnson and Knoll (1975) \\
\hline 22 & B Globorotalia truncatulinoides (F) & -9.20 & Thompson and Sciarrillo (1978) \\
\hline 15 & T Rhizosolenia praebergonii (D) & $9.60-9.70$ & Hays et al. (1969) \\
\hline 16 & T Pterocanium prismatium (R) & $9.70-9.80$ & $\begin{array}{l}\text { Hays et al. (1969), Johnson } \\
\text { and Knoll (1975) }\end{array}$ \\
\hline 17 & T Discoaster brouweri $(\mathbf{N})$ & 10.10 & Gartner (1973) \\
\hline 31 & B Globorotalia tosaensis (F) & -10.50 & Hays et al. (1969) \\
\hline
\end{tabular}

Table 6. Biostratigraphic events in Core V24-59.*

\begin{tabular}{|c|c|c|c|c|}
\hline & & Paleontological Event & $\begin{array}{l}\text { Depth in Core } \\
\text { (m) }\end{array}$ & References \\
\hline 3 & $\mathrm{~T}$ & Axoprunum angelinum (R) & 1.40 & Hays et al. (1969) \\
\hline 4 & $\mathrm{~T}$ & Pseudoemiliania lacunosa $(\mathrm{N})$ & 1.50 & Gartner (1973) \\
\hline 5 & B & Collosphaera tuberosa (R) & $\sim 1.80$ & Casey and Reynolds (1980) \\
\hline 7 & $\mathrm{~T}$ & Globorotalia tosaensis (F) & -3.0 & Hays et al. (1969) \\
\hline 9 & $\mathrm{~T}$ & Mesocena elliptica (S) & $3.80-3.90$ & Hays et al. (1969) \\
\hline 11 & $\mathrm{~T}$ & Anthocyrtidium angulare $(\mathrm{R})$ & 4.00 & Casey and Reynolds (1980) \\
\hline 22 & B & Globorotalia truncatulinoides (F) & $\sim 4.50$ & Hays et al. (1969) \\
\hline 13 & B & Mesocena elliptica (S) & -5.20 & Hays et al. (1969) \\
\hline 15 & $\mathrm{~T}$ & Rhizosolenia praebergonii (D) & $5.30-5.40$ & Hays et al. (1969) \\
\hline 16 & $\mathrm{~T}$ & Pterocanium prismatium $(\mathrm{R})$ & $5.30-5.40$ & Hays et al. (1969) \\
\hline 17 & $\mathrm{~T}$ & Discoaster brouweri $(\mathrm{N})$ & 5.50 & Gartner (1973) \\
\hline 20 & $\mathrm{~T}$ & Lamprocyrtis heteroporos ( $\mathbf{R})$ & $-5.50-5.60$ & Casey and Reynolds (1980) \\
\hline 21 & $\mathrm{~T}$ & Eucyrtidium calvertense ( $R$ ) & $-5.50-5.60$ & Casey and Reynolds (1980) \\
\hline 23 & $\mathrm{~T}$ & Discoaster surculus $(\mathrm{N})$ & 6.00 & Gartner (1973) \\
\hline 24 & $\mathrm{~T}$ & Thalassiosira convexa (D) & $6.60-6.70$ & Hays et al. (1969) \\
\hline 31 & B & Globorotalia tosaensis (F) & -7.40 & Hays et al. (1969) \\
\hline 25 & $\mathrm{~T}$ & Reticulofenestra pseudoumbilica $(\mathbb{N})$ & 7.90 & Gartner (1973) \\
\hline 27 & $\mathrm{~T}$ & Stichocorys peregrina $(\mathrm{R})$ & $8.40-8.50$ & Hays et al. (1969) \\
\hline 29 & $\mathrm{~T}$ & Globoquadrina altispira (F) & $8.80-8.90$ & Hays et al. (1969) \\
\hline 30 & $\mathrm{~T}$ & Sphaeroidinellopsis spp. (F) & $8.80-8.90$ & Hays et al. (1969) \\
\hline 36 & B & Discoaster asymmetricus (N) & 9.40 & Gartner (1973) \\
\hline 32 & $\mathrm{~T}$ & Globorotalia margaritae $(\mathrm{F})$ & -10.75 & Hays et al. (1969) \\
\hline 35 & $\mathrm{~T}$ & "Globigerina" nepenthes (F) & -10.75 & Hays et al. (1969) \\
\hline 41 & B & Pterocanium prismatium $(\mathrm{R})$ & -11.00 & Hays et al. (1969) \\
\hline 37 & B & Lamprocyrtis heteroporos $(\mathrm{R})$ & -11.50 & Casey and Reynolds (1980) \\
\hline 36 & $\mathrm{~T}$ & Ommatartus penultimus $(\mathrm{R})$ & 11.80 & Hays et al. (1969) \\
\hline 33 & $\mathrm{~T}$ & Ceratolithus tricorniculatus $(\mathrm{N})$ & 12.00 & Gartner (1973) \\
\hline 39 & B & Ceratolithus rugosus (N) & 12.30 & Gartner (1973) \\
\hline
\end{tabular}

- See notes in Table 4.

It is not possible to identify with certainty at Site $\mathbf{3 1 0}$ the specific events of the carbonate sequence in Core 6 between GU3 and GI9. It is probable, however, that the next low-carbonate peak below GU3 at 47.6 meters is GI1. This assumption is supported by the similarity in the patterns of the high-carbonate interval between GU3 and GI1 in both core RC12-66 and Site 310, that is, a small trough in the center of a double-peak maximum. The stratigraphic level of this small trough coincides with the base of the Gauss at RC12-66, as well as Site 310 , according to the sedimentation-rate curve constructed by Vincent (this volume; see her fig. 7).

A problem arises at Site 157 with the first occurrence of $N$. jouseae, reported by Burckle (1978) at 300 meters, well below the FAD of $C$. rugosus. Based on this datum level, Burckle (1978) correlated RC12-66 and Site 157 sequences in conflict with carbonate stratigraphy correlations. In Burckle's interpretation, the carbonate double peaks associated with the FAD of $C$. rugosus in both RC12-66 and Site 157 do not correlate, and the pronounced low-carbonate peak at 300 meters at Site 157 correlates with a level of RC12-66 within the transition between GI9 and GI10. I follow Kaneps' (1973b) interpretation for the equivalence of the carbonate double maximum GI10-GI11-GI12 in both sequences, but I question Kaneps' correlation of the 300-meter low-carbonate peak of Site 157 with the very pronounced carbonate minimum GI17 of RC12-66. According to biostratigraphic correlations, based on paleontological events associated with the Miocene/Pliocene boundary, carbonate event GI17 of RC12-66 appears to be older than the 300-meter low-carbonate peak of Site 157 (see below). 
Table 7. Biostratigraphic events in Core RC12-66.*

\begin{tabular}{|c|c|c|c|c|}
\hline & & Paleontological Event & $\begin{array}{l}\text { Depth in Core } \\
\text { (m) }\end{array}$ & References \\
\hline 3 & $\mathrm{~T}$ & Axoprunum angelinum $(\mathrm{R})$ & 2.10 & Saito et al. (1975) \\
\hline 8 & $\mathrm{~T}$ & Nitzschia reinholdii (D) & -3.60 & Burckle (1978) \\
\hline 9 & $\mathrm{~T}$ & Mesocena elliptica (S) & $\sim 4.40$ & Saito et al. (1975), Burckle (1978) \\
\hline 7 & $\mathrm{~T}$ & Globorotalia tosaensis (F) & -4.70 & Thompson and Sciarrillo (1978) \\
\hline 13 & B & Mesocena elliptica (S) & $\sim 5.70$ & Saito et al. (1975), Burckle (1978) \\
\hline 15 & $\mathrm{~T}$ & Rhizosolenia praebergonii s.1. (D) & -6.00 & Saito et al. (1975), Burckle (1978) \\
\hline 22 & B & Globorotalia truncatulinoides (F) & -6.10 & Thompson and Sciarrillo (1978) \\
\hline 16 & $\mathrm{~T}$ & Pterocanium prismatium (R) & 6.30 & Saito et al. (1975) \\
\hline 17 & $\mathrm{~T}$ & Discoaster brouweri $(\mathrm{N})$ & $\sim 6.45$ & Burckle (1978) \\
\hline 18 & B & Pseudoeunotia doliolus (D) & $\sim 6.70$ & Saito et al. (1975), Burckle (1978) \\
\hline 24 & $\mathrm{~T}$ & Thalassiosira convexa (D) & 8.30 & Saito et al. (1975), Burckle (1978) \\
\hline 26 & $\mathrm{~T}$ & Nitzschia jouseae (D) & $\sim 9.10$ & Saito et al. (1975) \\
\hline 27 & $\mathrm{~T}$ & Stichocorys peregrina (R) & 10.00 & Saito et al. (1975) \\
\hline 28 & B & Rhizosolenia praebergonii (D) & -10.80 & Saito et al. (1975), Burckle (1978) \\
\hline 30 & $\mathrm{~T}$ & Sphaeroidinellopsis spp. (F) & -11.20 & Saito et al. (1975) \\
\hline 35 & $\mathrm{~T}$ & "Globigerina" nepenthes (F) & -12.75 & Saito et al. (1975) \\
\hline 29 & $\mathrm{~T}$ & Globoquadrina aitispira (F) & -13.00 & Saito et al. (1975) \\
\hline 34 & $\mathrm{~T}$ & Ommatartus penultimus $(R)$ & $14.85-15.50$ & Saito et al. (1975) \\
\hline 41 & B & Pterocanium prismatium $(\mathbf{R})$ & $15.00-16.00$ & Saito et al. (1975) \\
\hline 33 & $\mathrm{~T}$ & Ceratolithus tricorniculatus (N) & 15.00 & Gartner (1973) \\
\hline 38 & B & Nitzschia jouseae (D) & -15.80 & Burckle (1978) \\
\hline 39 & B & Ceratolithus rugasus $(\mathrm{N})$ & 16.10 & Gartner (1973) \\
\hline 40 & B & Coscinodiscus nodulifer var. cyclopus (D) & -16.60 & Burckle (pers. comm.) \\
\hline 42 & B & Sphaeroidinella dehiscens (F) & -17.20 & Saito et al. (1975) \\
\hline 43 & B & Ceratolithus acutus $(\mathrm{N})$ & 18.00 & Gartner (1973) \\
\hline 44 & $\mathrm{~T}$ & Thalassiosira miocenica (D) & -18.35 & Burckle (1978) \\
\hline 46 & B & Globorotalia tumida $(\mathrm{F})$ & -18.40 & Saito et al. (1975) \\
\hline 45 & $\mathrm{~T}$ & Dictyocha navicula (S) & -18.60 & Burckle (pers. comm.) \\
\hline 47 & $\mathrm{~T}$ & Globoquadrina dehiscens (F) & -18.70 & Saito et al. (1975) \\
\hline 48 & $\mathrm{~T}$ & Asterolampra acutilaba (D) & -18.80 & Burckle (pers. comm.) \\
\hline 49 & B & Dictyocha navicula (S) & -19.20 & Burckle (pers. comm.) \\
\hline 32 & $\mathrm{~T}$ & Globorotalia margaritae (F) & -19.40 & Saito et al. (1975) \\
\hline 50 & $\mathrm{~T}$ & Nitzschia miocenica (D) & -20.25 & Saito et al. (1975), Burckle (1978) \\
\hline 51 & $\mathrm{~T}$ & Discoaster quinqueramus $(\mathrm{N})$ & 20.40 & Gartner (1973) \\
\hline 52 & $\mathrm{~T}$ & Nitzschia miocenica var, elongata (D) & -29.90 & Burckle (pers. comm.) \\
\hline 53 & B & Globorotalia margaritae $(\mathrm{F})$ & -21.10 & Saito et al. (1975) \\
\hline 54 & B & Pulleniatina primalis (F) & -22.50 & Saito et al. (1975) \\
\hline 55 & & Thalassiosira praeconvexa (D) & -22.95 & Burckle (pers. comm.) \\
\hline 56 & $\mathrm{~T}$ & Cussia praepalacea (D) & -24.00 & Burckle (pers. comm.) \\
\hline 57 & & Thalassiosira convexa var. aspinosa (D) & -24.10 & Burckle (pers. comm.) \\
\hline 58 & B & Thalassiosira miocenica (D) & -24.20 & Burckle (pers, comm.) \\
\hline 59 & & Thalassiosira praeconvexa (D) & -25.80 & Saito et al. (1975) \\
\hline 60 & & Nitzschia miocenica var, elongata (D) & -26.00 & Burckle (pers. comm.) \\
\hline 61 & & och 6 Carbon Shift & -26.00 & Keigwin and Shackleton (1980) \\
\hline 62 & & Stichocorys peregrina (D) & -26.00 & Saito et al. (1975) \\
\hline
\end{tabular}

-See notes in Table 4.

Table 8. Biostratigraphic events in Core $\mathrm{RC12}-65$. $^{*}$

\begin{tabular}{|c|c|c|c|c|c|}
\hline & & Paleontological Event & $\begin{array}{l}\text { Depth in Core } \\
\text { (m) }\end{array}$ & References & Remarks \\
\hline 56 & $\mathrm{~T}$ & Cussia praepalacea & $\sim 10.70$ & Burckle (pers. comm.) & \\
\hline 57 & B & Thalassiosira convexa var. aspinosa (D) & $\sim 11.10$ & Burckle (pers. comm.) & \\
\hline 58 & B & Thalassiosira miocenica (D) & 11.20 & Saito et al. (1975) & \\
\hline 59 & B & Thalassiosira praeconvexa (D) & 11.40 & Saito et al. (1975) & \\
\hline 60 & B & Nitzchia miocenica var. elongata (D) & $\sim 11.45$ & Burckle (pers. comm.) & \\
\hline 62 & B & Stichocorys peregrina $(\mathrm{R})$ & $10.80-12.00$ & Saito et al. (1975) & \\
\hline 64 & B & Nitzschia miocenica (D) & $\sim 12.40$ & Burckle (pers. comm.) & \\
\hline 65 & $\mathrm{~T}$ & Cussia paleacea (D) & -12.50 & Burckle (pers. comm.) & \\
\hline 69 & $\mathrm{~T}$ & Ommatartus hughesi $(\mathrm{R})$ & $\sim 15.30$ & Opdyke (1972); Ryan et al. (1974) & $\begin{array}{l}\text { Occurs here in a higher } \\
\text { magnetostratigraphic position } \\
\text { than that reported by Theyer } \\
\text { et al. (1978) in upper Epoch } 9 .\end{array}$ \\
\hline 66 & $\mathrm{~T}$ & Thalassiosira burckliana (D) & -15.70 & Burckle (pers. comm.) & \\
\hline 67 & $\mathrm{~T}$ & Coscinodiscus yabei (D) & $\sim 17.25$ & Burckle (pers. comm.) & \\
\hline 68 & B & Thalassiosira burckliana (D) & $\sim 18.10$ & Burckle (pers. comm.) & \\
\hline 72 & $\mathrm{~T}$ & Coscinodiscus vetustissimus var. javanicus (D) & $\sim 20.90$ & Ryan et al. (1974) & \\
\hline 75 & $\mathrm{~B}$ & Coscinodiscus vetustissimus var. javanicus (D) & $\sim 22.00$ & Ryan et al. (1974) & \\
\hline 74 & $\mathrm{~T}$ & Discoaster hamatus $(\mathrm{N})$ & $\sim 22.30$ & Ryan et al. (1974) & $\begin{array}{l}\text { Occurs too low here because } \\
\text { of dissolution. In V19-99 it } \\
\text { occurs higher, within the } \\
\text { range of } C \text {. vetustissimus var. } \\
\text { javanicus (Burckle, 1972). }\end{array}$ \\
\hline
\end{tabular}

*See notes in Table 4. 
Table 9. Biostratigraphic events at DSDP Site 157.

\begin{tabular}{|c|c|c|c|c|}
\hline & & \multirow[b]{2}{*}{ Paleontological Event } & \multicolumn{2}{|c|}{ Position in Cores and Sub-bottom Depth (m) } \\
\hline & & & $\begin{array}{l}\text { Sample in Which } \\
\text { Event Occurs }\end{array}$ & $\begin{array}{l}\text { Next Higher or } \\
\text { Lower Sample }\end{array}$ \\
\hline \multicolumn{5}{|c|}{ Planktonic toraminifers (Keigwin, ${ }^{1}$ 1976; Kaneps, ${ }^{2}$ 1973a) } \\
\hline 22 & B & Globorotalia truncatulinoides ${ }^{1}$ & $8.4,100 \mathrm{~cm}(78.5 \mathrm{~m})$ & $9-1,103 \mathrm{~cm}(83.0 \mathrm{~m})$ \\
\hline 7 & $\mathrm{~T}$ & Globorotalia tosaensis $^{2}$ & $9-6,122 \mathrm{~cm}(90.72 \mathrm{~m})$ & $9.5,107 \mathrm{~cm}(90.07 \mathrm{~m})$ \\
\hline 29 & $\mathrm{~T}$ & Globoquadrina altispirg $^{2}$ & $19-6,121 \mathrm{~cm}(179.71 \mathrm{~m})$ & $19-3$ \\
\hline 31 & B & Globorotalia tosaensis $^{2}$ & $21-1,121 \mathrm{~cm}(190.21 \mathrm{~m})$ & $21-2,121 \mathrm{~cm}(193.21 \mathrm{~m})$ \\
\hline 30 & $\mathrm{~T}$ & Sphaeroidinellopsis spp. ${ }^{2}$ & $21-4,121 \mathrm{~cm}(194.71 \mathrm{~m})$ & $21-3$ \\
\hline 32 & $\mathrm{~T}$ & Globorotalia margaritae $^{2}$ & $29-3,120 \mathrm{~cm}(265.20 \mathrm{~m})$ & $29-2,120 \mathrm{~cm}(263.7 \mathrm{~m})$ \\
\hline 35 & $\dot{\mathrm{T}}$ & "Globigerina" nepenthes 2 & $30-2,120 \mathrm{~cm}(272.7 \mathrm{~m})$ & $30-1,120 \mathrm{~cm}(271.20 \mathrm{~m})$ \\
\hline 42 & B & Sphaeroidinella dehiscens ${ }^{2}$ & $30-3,120 \mathrm{~cm}(274.20 \mathrm{~m})$ & $30-4,120 \mathrm{~cm}(275.70 \mathrm{~m})$ \\
\hline 53 & B & Globorotalia margaritae ${ }^{2}$ & $33-6,98 \mathrm{~cm}(305.48 \mathrm{~m})$ & $34, \mathrm{CC}(315 \mathrm{~m})$ \\
\hline & B & Globorotalia tumida ${ }^{1}$ & $37-1,135 \mathrm{~cm}(334.4 \mathrm{~m})$ & $38-1,137 \mathrm{~cm}(343.4 \mathrm{~m})$ \\
\hline \multicolumn{5}{|c|}{ Diatoms (Burckle, 1978) } \\
\hline 8 & $\mathrm{~T}$ & Nitzchia reinholdii & $-31 \mathrm{~m}$ & \\
\hline 9 & $\dot{T}$ & Mesocena elliptica & $\sim 37 \mathrm{~m}$ & \\
\hline 15 & $\mathrm{~T}$ & Rhizosolenia praebergonii s.l. & $-89 \mathrm{~m}$ & \\
\hline 18 & B & Pseudoeunotia doliolus & $-88 \mathrm{~m}$ & \\
\hline 24 & $\mathrm{~T}$ & Thalassiosira convexa & $\sim 107 \mathrm{~m}$ & \\
\hline 26 & $\mathrm{~T}$ & Nitzchia jouseae & $-145 \mathrm{~m}$ & \\
\hline 28 & B & Rhizosolenia praebergonii & $-176 \mathrm{~m}$ & \\
\hline 38 & B & Nitzchia jouseae & $-300 \mathrm{~m}$ & \\
\hline 44 & $\mathrm{~T}$ & Thalassiosira miocenica & $-325 \mathrm{~m}$ & \\
\hline \multicolumn{5}{|c|}{ Calcareous nannofossils (Bukry, 1973) } \\
\hline 17 & $\mathrm{~T}$ & Discoaster brouweri & $9-2,50 \mathrm{~cm}(84.0 \mathrm{~m})$ & $9.3,84 \mathrm{~m}(85.84 \mathrm{~m})$ \\
\hline 33 & $\dot{T}$ & Ceratolithus trīcorniculatus & $28.5 .0 \mathrm{~cm}(258.0 \mathrm{~m})$ & $28-5,119 \mathrm{~cm}(259.19 \mathrm{~m})$ \\
\hline 39 & B & Ceratolithus rugosus & $29-2,119 \mathrm{~cm}(263.69 \mathrm{~m})$ & $29-3,119 \mathrm{~cm}(265.19 \mathrm{~m})$ \\
\hline 43 & B & Ceratolithus acutus & $35.1,119 \mathrm{~cm}(316.19 \mathrm{~m})$ & $36-1,119 \mathrm{~cm}(325.19 \mathrm{~m})$ \\
\hline \multicolumn{5}{|c|}{ Radiolarians (Dinkelman, 1973) } \\
\hline 5 & B & Collosphoera tuberosa & $2-1,123 \mathrm{~cm}(20.23 \mathrm{~m})$ & $2-3,124 \mathrm{~cm}(23.24 \mathrm{~m})$ \\
\hline 11 & $\mathrm{~T}$ & Anthocyrtidium a & $6-5,118 \mathrm{~cm}(63.68 \mathrm{~m})$ & $6 . \mathrm{CC}(64.0 \mathrm{~m})$ \\
\hline 16 & $\mathrm{~T}$ & Pterocanium prismatium & $9-6,126 \mathrm{~m}(90.76 \mathrm{~m})$ & $9, \mathrm{CC}(91.0 \mathrm{~m})$ \\
\hline 27 & $\mathrm{~T}$ & Stichocorys peregrina & $18-5,123 \mathrm{~cm}(167.73 \mathrm{~m})$ & $18, \mathrm{CC}(171.0 \mathrm{~m})$ \\
\hline 41 & B & Plerocanium prismatium & $30-3,123 \mathrm{~cm}(274.23 \mathrm{~m})$ & $30-5,123 \mathrm{~cm}(277.23 \mathrm{~m})$ \\
\hline
\end{tabular}

Note: See footnotes in Table 4.

The FAD of Pterocanium prismatium, although only broadly defined (Table 7) is associated with the FADs of $N$. jouseae and $C$. rugosus in both RC12-66 and Site 158. It is also associated with the FAD of C. rugosus at Site 157, well above the first occurrence of $N$. jouseae as reported by Burckle (1978), and is thus an additional support for the lower-than-normal stratigraphic range of $N$. jouseae at Site 157.

It should be noted that in the various proposed schemes of correlation between Sites 157 and RC12-66 the problem of diachronism of the coiling change in Pulleniatina primalis (occurring earlier in the eastern equatorial Pacific than in the central Pacific) remains.

The nature of the last occurrence level of Ommatartus penultimus reported by Hays et al. (1969) and Saito et al. (1975) near the FAD of P. prismatium in V24-59 and RC12-66, between events B and C of the Gilbert, is obscure (the taxonomic ambiguity of this species has been discussed by Westberg and Riedel, 1978). This LAD does not agree with Casey and Reynolds (1980) who report the last occurrence of this species in V24-59, in the upper reversed Gilbert, in the same magnetostratigraphic position as that given by Theyer et al. (1978). At Site 157, Dinkelman (1973) reports this species ranging up into the Pleistocene.

The FAD of Coscinodiscus nodulifer var. cyclopus occurs in Core RC12-66 at the base of the Gilbert C event, within the transition between carbonate minima GI13 and GI14. The first occurrence of this species at 56.5 meters at Site 310 allows the identification at this site of carbonate minimum GI13 at 55.9 meters, slightly above this diatom event. The simultaneous occurrence of 56.5 meters of the first $C$. nodulifer var. cyclopus, the last Thalassiosira miocenica, and the last Dictyocha
Table 10. Biostratigraphic events at DSDP Site 158.

\begin{tabular}{|c|c|c|c|c|}
\hline & \multirow{2}{*}{\multicolumn{2}{|c|}{ Paleontological Event }} & \multicolumn{2}{|c|}{ Position in Cores and Sub-bottom Depth (m) } \\
\hline & & & $\begin{array}{l}\text { Sample in Which } \\
\text { Event Occurs }\end{array}$ & $\begin{array}{l}\text { Next Higher or } \\
\text { Lower Sample }\end{array}$ \\
\hline \multicolumn{5}{|c|}{ Planktonic Foraminifers (Kaneps, 1973a) } \\
\hline 29 & $\mathrm{~T}$ & Globoquadrina altispira & $4.4,21 \mathrm{~cm}(31.71 \mathrm{~m})$ & $4.4 .71 \mathrm{~cm}(32.21 \mathrm{~m})$ \\
\hline & $\mathrm{T}$ & Sphaeroidinellopsis spp. & $5.6,71 \mathrm{~cm}(44.21 \mathrm{~m})$ & $5-5,122 \mathrm{~cm}(40.22 \mathrm{~m})$ \\
\hline 32 & $\mathrm{~T}$ & Globorotalia margaritae & $5-6.71 \mathrm{~cm}(44.21 \mathrm{~m})$ & $5-5,122 \mathrm{~cm}(40.22 \mathrm{~m})$ \\
\hline$\$ 3$ & B & Globorotalia margaritae & $5-6,71 \mathrm{~cm}(44.21 \mathrm{~m})$ & $5-6.121 \mathrm{~cm}(44.71 \mathrm{~m})$ \\
\hline 35 & $\mathrm{~T}$ & "Globigerina" nepenthes & $6-6.121 \mathrm{~cm}(53.71 \mathrm{~m})$ & $6.5,122 \mathrm{~cm}(52.22 \mathrm{~m})$ \\
\hline & B & Sphaeroidinella dehiscens & $10-4,84 \mathrm{~cm}(86.34 \mathrm{~m})$ & $10-4,121 \mathrm{~cm}(86.78 \mathrm{~m})$ \\
\hline 46 & B & Globorotalia tumida & $10-5,84 \mathrm{~cm}(87.84 \mathrm{~m})$ & $10-5,128 \mathrm{~cm}(88.28 \mathrm{~m})$ \\
\hline 54 & B & Pulleniatina primalis & $14-1,36 \mathrm{~cm}(117.36 \mathrm{~m})$ & $14.2,71 \mathrm{~cm}(118.21 \mathrm{~m})$ \\
\hline 47 & $\mathrm{~T}$ & Globoquadrina dehiscens & $14-6.71 \mathrm{~cm}(125.21 \mathrm{~m})$ & $14-5,71 \mathrm{~cm}(124.21 \mathrm{~m})$ \\
\hline 73 & B & Neogloboquadrina acostaensis & $23-1,54 \mathrm{~cm}(198.54 \mathrm{~m})$ & $23-2,121 \mathrm{~cm}(200.71 \mathrm{~m})$ \\
\hline 86 & B & "Globigerina" nepenthes & $27-3,121 \mathrm{~cm}(238.21 \mathrm{~m})$ & $27-4,151 \mathrm{~cm}(239.01 \mathrm{~m})$ \\
\hline \multirow[t]{5}{*}{84} & $\mathrm{~T}$ & Turborotalia mayeri & $28-1,114 \mathrm{~cm}(244.14 \mathrm{~m})$ & $27-6,134 \mathrm{~cm}(242.84 \mathrm{~m})$ \\
\hline & $\mathrm{T}$ & Turborotalia siakensis & $28-1,114 \mathrm{~cm}(244.14 \mathrm{~m})$ & $27-6,134 \mathrm{~cm}(242.84 \mathrm{~m})$ \\
\hline & $\mathrm{T}$ & Globorotalia lenguaensis & $30-5,96 \mathrm{~cm}(267.96 \mathrm{~m})$ & $30-4.49 \mathrm{~cm}(265.99 \mathrm{~m})$ \\
\hline & B & Globorotalia lenguaensis & $30-6,71 \mathrm{~cm}(269.21 \mathrm{~m})$ & $31-1,11 \mathrm{~cm}(270.11 \mathrm{~m})$ \\
\hline & $\mathrm{T}$ & Globorotalia fohsi s.l. & $32-2,96 \mathrm{~cm}(281.46 \mathrm{~m})$ & $32-1,113 \mathrm{~cm}(280.13 \mathrm{~m})$ \\
\hline \multicolumn{5}{|c|}{ Calcareous nannofossils (Bukry, 1973) } \\
\hline 25 & $T$ & Reticulofenestra pseudoumbilicu & $5.2 .126 \mathrm{~cm}(38.76 \mathrm{~m})$ & $5-2,40 \mathrm{~cm}(37.90 \mathrm{~m})$ \\
\hline 33 & $\mathrm{~T}$ & Ceratolithus tricorniculatus & $7-5,120 \mathrm{~cm}(61.20 \mathrm{~m})$ & $7-4,120 \mathrm{~cm}(59.70 \mathrm{~m})$ \\
\hline 39 & B & Ceratolithus rugosus & $8-4,120 \mathrm{~cm}(68.70 \mathrm{~m})$ & $8-6,120 \mathrm{~cm}(71.70 \mathrm{~m})$ \\
\hline 43 & B & Ceratolithus acutus & $9-5,120 \mathrm{~cm}(79.20 \mathrm{~m})$ & $9.6,120 \mathrm{~cm}(80.70 \mathrm{~m})$ \\
\hline & B & Amaurolithus primus & $17.5,70 \mathrm{~cm}(150.70 \mathrm{~m})$ & $17.6 .126 \mathrm{~cm}(152.76 \mathrm{~m})$ \\
\hline & B & Discoaster surculus & $19.4 .20 \mathrm{~cm}(165.20 \mathrm{~m})$ & $19.4,120 \mathrm{~cm}(166.20 \mathrm{~m})$ \\
\hline 74 & $\mathrm{~T}$ & Discoaster hamatus & $24-1,94 \mathrm{~cm}(207.94 \mathrm{~m})$ & $23-5.120 \mathrm{~cm}(205.20 \mathrm{~m})$ \\
\hline 85 & B & Discoaster hamatus & $28-2,45 \mathrm{~cm}(244.95 \mathrm{~m})$ & $28-2,80 \mathrm{~cm}(245.30 \mathrm{~m})$ \\
\hline & B & Catinaster coalitus & $28.5,7 \mathrm{~cm}(249.07 \mathrm{~m})$ & $28-5,120 \mathrm{~cm}(250.20 \mathrm{~m})$ \\
\hline \multicolumn{5}{|c|}{ Radiolarians (Dinkelman, 1973) } \\
\hline 27 & $\mathrm{~T}$ & Stichacorys peregrina & $5-1,128 \mathrm{~cm}(37.28 \mathrm{~m})$ & $4, \mathrm{CC}(36 \mathrm{~m})$ \\
\hline 41 & B & Pterocanium prismatium & $8-5,123 \mathrm{~cm}(68.73 \mathrm{~m})$ & $8, \mathrm{CC}(72 \mathrm{~m})$ \\
\hline 62 & B & Stichocorys peregrina & $16-2,74 \mathrm{~cm}(137.24 \mathrm{~m})$ & $16-4,74 \mathrm{~cm}(140.24 \mathrm{~m})$ \\
\hline 69 & $\mathrm{~T}$ & Ommatartus hughesi & $19-2,124 \mathrm{~cm}(164.74 \mathrm{~m})$ & $18, \mathrm{CC}(162 \mathrm{~m})$ \\
\hline 70 & B & Ommatartus penultimus & $19-4,124 \mathrm{~cm}(167.74 \mathrm{~m})$ & $19, \mathrm{CC}(171 \mathrm{~m})$ \\
\hline 71 & $\mathrm{~T}$ & Cannartus petterssoni & $20, \mathrm{CC}(180 \mathrm{~m})$ & $20-4,124 \mathrm{~cm}(175.74 \mathrm{~m})$ \\
\hline 76 & B & Acrobotrys tritubus & $20 . C C(180 \mathrm{~m})$ & $21-4,124 \mathrm{~cm}(185.74 \mathrm{~m})$ \\
\hline 77 & B & Ommatartus antepenultimus & $28-1,117 \mathrm{~cm}(244.17 \mathrm{~m})$ & $28.4,133 \mathrm{~cm}(248.83 \mathrm{~m})$ \\
\hline 78 & B & Ommatartus hughesi & $28-1,117 \mathrm{~cm}(244.17 \mathrm{~m})$ & $28-4,133 \mathrm{~cm}(248.83 \mathrm{~m})$ \\
\hline 79 & $\mathrm{~T}$ & Stichocorys wolfii & $28-4,133 \mathrm{~cm}(248.83 \mathrm{~m})$ & $28-1,117 \mathrm{~cm}(244,17 \mathrm{~m})$ \\
\hline 80 & $\mathrm{~T}$ & Cyrtocapsella cornuta & $30-5,99 \mathrm{~cm}(267.99 \mathrm{~m})$ & $30-3,74 \mathrm{~cm}(264.74 \mathrm{~m})$ \\
\hline 83 & $\tau$ & Cyrtocapsella tetrapera & $31, C C(279 \mathrm{~m})$ & $31-1,14 \mathrm{~cm}(270.14 \mathrm{~m})$ \\
\hline 82 & B & Cannartus petterssoni & $32, \mathrm{CC}(287 \mathrm{~m})$ & $33-1,108 \mathrm{~cm}(288.08 \mathrm{~m})$ \\
\hline & $\mathrm{T}$ & Dorcadospyris alata & $34, \mathrm{CC}(305 \mathrm{~m})$ & $34-1,76 \mathrm{~cm}(296,76 \mathrm{~m})$ \\
\hline \multicolumn{5}{|c|}{ Diatoms (Burckle and Opdyke. ${ }^{1}$ 1977; Burckle, ${ }^{2}$ pers. comm.) } \\
\hline 38 & B & Nitzschia jouseae $^{1}$ & $\sim 72 \mathrm{~m}$ & \\
\hline 44 & & Thalassiosira miocenica ${ }_{2}^{2}$ & $-82 \mathrm{~m}$ & \\
\hline 48 & $\mathrm{~T}$ & Asterolampra acutiloba ${ }^{2}$ & $-100 \mathrm{~m}$ & \\
\hline 50 & & Nitzschia miocenica ${ }^{2}$ & $-110 \mathrm{~m}$ & \\
\hline 52 & & Nitzschia miocenica var, elongata ${ }^{2}$ & $-118 m$ & \\
\hline 55 & $\mathrm{~T}$ & Thalassiosina praeconvexa ${ }^{2}$ & $-120 \mathrm{~m}$ & \\
\hline 56 & & Cussia praepalacea ${ }^{2}$ & $-123 m$ & \\
\hline 57 & & Thalassiosira convexa var, aspinoso ${ }^{2}$ & $-123 m$ & \\
\hline 58 & B & Thalassiosira miocenica ${ }^{2}$ & $-126 m$ & \\
\hline 59 & & Thalassiosira praeconvexa ${ }^{2}$, & $-132 \mathrm{~m}$ & \\
\hline 60 & & Nitzschia miocenica, var, elongata ${ }^{2}$ & $-136.5 \mathrm{~m}$ & \\
\hline 63 & & Nitzschia reinholdii ${ }_{2}^{2}$ & $-144 \mathrm{~m}$ & \\
\hline 64 & & Nitzschia miocenica ${ }^{2}$ & $-151 m$ & \\
\hline 65 & & Cussia palacea ${ }^{2}$ & $-153 m$ & \\
\hline 66 & & Thalassiosira burckliana ${ }^{2}$ & $-166 \mathrm{~m}$ & \\
\hline 67 & & Coscinodiscus yabei ${ }^{2}$ & $\sim 174 \mathrm{~m}$ & \\
\hline & B & Thalassiasira burckliana ${ }^{2}$ & $-185 m$ & \\
\hline \multicolumn{5}{|c|}{ Silicoflagellates (Burckle, pers. comm.) } \\
\hline & & Dictyocha navicula & $\begin{array}{l}-96 \mathrm{~m} \\
-100 \mathrm{~m}\end{array}$ & \\
\hline & B & Dictyocha navicula & $-100 \mathrm{~m}$ & \\
\hline \multicolumn{5}{|c|}{ Isotopic Event (Keigwin, 1979) } \\
\hline 61 & & och 6 Carbon Shift & $-137 m$ & \\
\hline
\end{tabular}

Note; See footnotes in Table 4.

navicula indicates an unconformity at this level at Site 310 , which omits at least the upper half of the lower normal Gilbert and encompasses carbonate minima GI15 and GI17. The unconformity does not entirely omit the lower normal Gilbert, as shown by the LAD of Asterolampra acutiloba, which marks the Gilbert/ Epoch 5 boundary slightly lower in the section at 57.6 meters. This hiatus appears to be equivalent to a time span of about 0.4 m.y., based on extrapolations from the accumulation rate of underlying sediments (see sedimentation-rate curve in Vincent, this volume, her fig. 7); the hiatus appears to span the Miocene/Pliocene boundary.

The Miocene/Pliocene boundary (= Messinian/Zanclean boundary) has been shown to be coeval with a level 
Table 11. Biostratigraphic events at DSDP Site 310.

\begin{tabular}{|c|c|c|c|c|c|}
\hline & & \multirow[b]{2}{*}{ Paleontolugical Event } & \multicolumn{2}{|c|}{ Position in Cores and Sub-bottom Depth (m) } & \multirow[b]{2}{*}{ Remarks } \\
\hline & & & $\begin{array}{l}\text { Sample in Which } \\
\text { Event Oecurs }\end{array}$ & $\begin{array}{l}\text { Next Higher or } \\
\text { Lower Sample }\end{array}$ & \\
\hline \multicolumn{6}{|c|}{ Planktonic foraminifers (Vincent, ${ }^{1}$ 1975; Keller, ${ }^{2}$ 1978; Keller, ${ }^{3}$ 1980) } \\
\hline 22 & B &  & $3.6,123 \mathrm{~cm}(23.23 \mathrm{~m})$ & $3 . \mathrm{CC}(24 \mathrm{~m})$ & \\
\hline 7 & $\mathrm{~T}$ & Globorotalia tosaensis $^{2}$ & $2-3,80 \mathrm{~cm}(8.80 \mathrm{~m})$ & $2.2,90 \mathrm{~cm}(7.40 \mathrm{~m})$ & \\
\hline 31 & B & Globorotalia tosaensis 1 & 3.CC $(24 \mathrm{~m})$ & $4-1,56 \mathrm{~cm}(24.56 \mathrm{~m})$ & \\
\hline 30 & $\mathrm{~T}$ & Sphaeroidinellopsis spp ${ }^{2}$ & $6-1,110 \mathrm{~cm}(44.10 \mathrm{~m})$ & $6-1.68 \mathrm{~cm}(43.68 \mathrm{~m})$ & \\
\hline 42 & B & Sphaeroidinella dehiscenș ${ }^{1}$ & $6.4,122 \mathrm{~cm}(48.72 \mathrm{~m})$ & $6-5,144 \mathrm{~cm}(50.44 \mathrm{~m})$ & \\
\hline 32 & $\mathrm{~T}$ & Globorotatia margaritae $^{2}$ & $6-5.18 \mathrm{~cm}(49.18 \mathrm{~m})$ & $6-4,90 \mathrm{~cm}(48 \mathrm{~m})$ & \\
\hline 35 & $\dot{\mathrm{T}}$ & "Globigerina" nepenthes ${ }^{2}$ & $7.3,62 \mathrm{~cm}(56.12 \mathrm{~m})$ & $7-2,140 \mathrm{~cm}(55,40 \mathrm{~m})$ & \\
\hline 46 & B & Globorotalia tumida ${ }^{2}$ & $7.3,120 \mathrm{~cm}(56.7 \mathrm{~m})$ & $7.4,10 \mathrm{~cm}(57.10 \mathrm{~m})$ & \\
\hline 53 & B & Globorotalia margaritae ${ }^{3}$ & $8-1,110 \mathrm{~cm}(63.10 \mathrm{~m})$ & $8-1,190 \mathrm{~cm}(63.90 \mathrm{~m})$ & \\
\hline 47 & $\vec{T}$ & Globoquadrina dehiscens ${ }^{1}$ & $8-6,10 \mathrm{~cm}(69.10 \mathrm{~m})$ & $8-6,131 \mathrm{~cm}(70.81 \mathrm{~m})$ & \\
\hline \multirow{2}{*}{73} & B & Neogioboquadrina acostaensis ${ }^{3}$ & $9.3,90 \mathrm{~cm}(75,40 \mathrm{~m})$ & $9-3,110 \mathrm{~cm}(75.60 \mathrm{~m})$ & \\
\hline & & Globorotalia lenguaensis ${ }^{3}$ & $9-5,90 \mathrm{~cm}(78.40 \mathrm{~m})$ & $9-6,22 \mathrm{~cm}(79.22 \mathrm{~m})$ & \\
\hline 86 & B & "Globigerina" nepenthes ${ }^{3}$ & $9-6,22 \mathrm{~cm}(79,22 \mathrm{~m})$ & $9-6.90 \mathrm{~cm}(79.90 \mathrm{~m})$ & \\
\hline \multicolumn{6}{|c|}{ Calcareous nannofossils (Bukry, ${ }^{1}$ 1975; R. Schmidt, ${ }^{2}$ pers. comm.) } \\
\hline 4 & $\mathrm{~T}$ & Emiliania ovata $(=P \text {. lacunosa })^{1}$ & $2-3,122 \mathrm{~cm}(9.22 \mathrm{~m})$ & $2-1,81 \mathrm{~cm}(5.81 \mathrm{~m})$ & \\
\hline 17 & $\dot{\mathrm{T}}$ & Discoaster brouweri ${ }^{2}$ & 4.2 & $4-1$ & \\
\hline 23 & $\dot{T}$ & Discoaster surculus ${ }^{2}$ & 4.5 & $4-4$ & \\
\hline 25 & $\dot{\mathrm{T}}$ & Reticulofenestra pseudoumbilicar ${ }^{2}$ & 6.5 & 6.4 & \\
\hline 39 & B & Ceratolithus rugosus & $7.2,73 \mathrm{~cm}(54.73 \mathrm{~m})$ & $7.3,90 \mathrm{~cm}(56.40)$ & \\
\hline 43 & B & Ceratolithus acutus ${ }^{1}$ & $7.3,90 \mathrm{~cm}(56.40 \mathrm{~m})$ & $7-4,52 \mathrm{~cm}(56.52 \mathrm{~m})$ & \\
\hline \multirow[t]{2}{*}{51} & $\mathrm{~T}$ & Discoaster quinqueramus ${ }^{1}$ & $7-4,52 \mathrm{~cm}(56.52 \mathrm{~m})$ & $7-3,90 \mathrm{~cm}(56.40 \mathrm{~m})$ & \\
\hline & B & Amaurolithus primus 1 & $8-4,82 \mathrm{~cm}(67.32 \mathrm{~m})$ & $8.5,72 \mathrm{~cm}(68.72 \mathrm{~m})$ & \\
\hline 74 & $\mathrm{~T}$ & Discoaster hamatus? & $9-3,50 \mathrm{~cm}(75.0 \mathrm{~m})$ & $8-3,122 \mathrm{~cm}(75,72 \mathrm{~m})$ & \\
\hline 85 & B & Discoaster hamatus ${ }^{1}$ & $9-5,49 \mathrm{~cm}(77.99 \mathrm{~m})$ & $9-5,123 \mathrm{~cm}(78.73 \mathrm{~m})$ & \\
\hline 87 & B & Catinaster coalitus 1 & $9-5,123 \mathrm{~cm}(78.73 \mathrm{~m})$ & $9-6.149 \mathrm{~cm}(80.49 \mathrm{~m})$ & \\
\hline \multicolumn{6}{|c|}{ Radiolarians (Foreman, 1975) } \\
\hline 3 & $\mathrm{~T}$ & Axoprunum angelimum & $1-3,110 \mathrm{~cm}(4,10 \mathrm{~m})$ & $1-2,40 \mathrm{~cm}(1.90 \mathrm{~m})$ & \\
\hline 21 & $\mathrm{~T}$ & Eucyrtidium calvertense & $2-3,119 \mathrm{~cm}(9.19 \mathrm{~m})$ & $2-2,120 \mathrm{~cm}(7.70 \mathrm{~m})$ & \\
\hline 12 & $\mathrm{~T}$ & Lamprocyrtis neoheteroporos & $2-3,119 \mathrm{~cm}(9.19 \mathrm{~m})$ & $2-2.120 \mathrm{~cm}(7.70 \mathrm{~m})$ & $\begin{array}{l}\text { Occurs here higher } \\
\text { than in the tropics } \\
\text { in the } A \text {. angeli- } \\
\text { num Zone, as at } \\
\text { DSDP } 173 \text { (Kling. } \\
\text { 1973) }\end{array}$ \\
\hline 10 & $T$ & Eucyrtidium matuyamai & $2, \mathrm{CC}(14.50 \mathrm{~m})$ & $2-4,103 \mathrm{~cm}(10.53 \mathrm{~m})$ & \\
\hline 20 & $T$ & Lamprocyrtis heteroporos & $3.3,130 \mathrm{~cm}(\mathrm{~m})$ & $3-2,128 \mathrm{~cm}(17.28 \mathrm{~m})$ & \\
\hline 19 & $\mathrm{~B}$ & Eucyrtidium matuyamai & $3, \mathrm{CC}(24.0 \mathrm{~m})$ & $4-1,50 \mathrm{~cm}(24.5 \mathrm{~m})$ & \\
\hline 27 & $\mathrm{~T}$ & Stichocorys peregrina & $5-2,122 \mathrm{~cm}(36.22 \mathrm{~m})$ & $5-1,124 \mathrm{~cm}(34,74 \mathrm{~m})$ & \\
\hline 37 & B & Lamprocyrtis heteroporos & $7-1,133 \mathrm{~cm}(53.83 \mathrm{~m})$ & $7-3.125 \mathrm{~cm}(56.75 \mathrm{~m})$ & \\
\hline 62 & $\mathrm{~B}$ & Stichocorys peregrina & $8.4,124 \mathrm{~cm}(67.74 \mathrm{~m})$ & $8-5,125 \mathrm{~cm}(69.25 \mathrm{~m})$ & \\
\hline 69 & $\mathrm{~T}$ & Ommatartus hughesi & $8.5,125 \mathrm{~cm}(69.25 \mathrm{~m})$ & $8-4,124 \mathrm{~cm}(67.74 \mathrm{~m})$ & \\
\hline & B & Ommatartus penultimus & $8.5,125 \mathrm{~cm}(69.25 \mathrm{~m})$ & $8-6,100 \mathrm{~cm}(70.5 \mathrm{~m})$ & \\
\hline \multicolumn{6}{|c|}{ Diatoms (Koizumi, ${ }^{1} 1975$; J. Barron, ${ }^{2}$ pers. comm.; L. Burckle, ${ }^{3}$ pers. comm.) } \\
\hline 8 & $\mathrm{~T}$ & Nitzschia reinholdii ${ }^{1}$ & $2-2,130 \mathrm{~cm}(7.80 \mathrm{~m})$ & $1.4,149 \mathrm{~cm}(4.99 \mathrm{~m})$ & \\
\hline 18 & B & Pseudoeunotia doliolus ${ }^{1}$ & $3, \mathrm{CC}(24.0 \mathrm{~m})$ & $4-2,101 \mathrm{~cm}(26.61 \mathrm{~m})$ & \\
\hline 24 & $\mathrm{~T}$ & Thalassiosira conyexa $a^{1,2}$ & $4.4-80 \mathrm{~cm}(30.80 \mathrm{~m})$ & $4-2,101 \mathrm{~cm}(26.61 \mathrm{~m})$ & \\
\hline 26 & $\mathrm{~T}$ & Nitzschia jouseae ${ }_{2}^{2}$ & $4,4.80 \mathrm{~cm}(30.80 \mathrm{~m})$ & $5-1,60 \mathrm{~cm}(34.10 \mathrm{~m})$ & \\
\hline 38 & B & Nitzschia jouseae ${ }^{3}$ & $-54 \mathrm{~m}$ & & \\
\hline 40 & B & Cascinodiscus nodulifer var. cyclopus ${ }^{3}$ & $7.3(56.5 \mathrm{~m})$ & & \\
\hline 44 & $\bar{T}$ & Thalassiosira miocenica ${ }_{3}^{3}$ & $7.3(56.5 \mathrm{~m})$ & & \\
\hline 48 & $\dot{T}$ & Asterolampra acutiloba ${ }^{3}$ & $7-4(57.6 \mathrm{~m})$ & & \\
\hline 50 & $\dot{T}$ & Nitzschia miocenica ${ }^{3}$ & $7.5(59.6 \mathrm{~m})$ & & \\
\hline 55 & $\mathrm{~T}$ & Thalassiosira praeconvexa ${ }^{3}$ & $7.5(60.0 \mathrm{~m})$ & & \\
\hline 57 & B & Thalassiosira convexa var. aspinosa ${ }^{3}$ & $7.6(61.7 \mathrm{~m})$ & & \\
\hline 58 & B & Thalassiosira miocenica ${ }^{3}$ & $8.1(62.5 \mathrm{~m})$ & & \\
\hline 59 & B & Thalassiosira praeconvexa ${ }^{3}$ & $8.4(66.6 \mathrm{~m})$ & & \\
\hline 64 & $\mathrm{~B}$ & 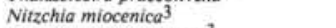 & $8.9(67.5 \mathrm{~m})$ & & \\
\hline & $\mathrm{T}$ & Thalassiasira burckliana $^{3}$ & $8.5(69.3 \mathrm{~m})$ & & \\
\hline \multicolumn{6}{|c|}{ Silicoflagellates (Bukry, ${ }^{1} 1978 ;$ L. Burckle, ${ }^{2}$ pers. comm.) } \\
\hline 9 & $\mathrm{~T}$ & Mesocena elliptica 1 & $2 \cdot 2,20 \mathrm{~cm}(6.70 \mathrm{~m})$ & $1-4,27 \mathrm{~cm}(4.77 \mathrm{~m})$ & \\
\hline & B & Mesocena elliptica ${ }^{1}$ & $3.3,20 \mathrm{~cm}(17,70 \mathrm{~m})$ & $3-6.20 \mathrm{~cm}(22.20 \mathrm{~m})$ & \\
\hline & & Dictyocha navicula ${ }^{2}$ & $7-3(56.5 \mathrm{~m})$ & & \\
\hline & B & Dictyocha navicula ${ }^{2}$ & $-58 \mathrm{~m}$ & & \\
\hline \multicolumn{6}{|c|}{ Isotopic Event (Keigwin, 1979): } \\
\hline 61 & & och 6 Carbon Shift & $-67 \mathrm{~m}$ & & \\
\hline
\end{tabular}

Note: See footnotes in Table 4.

close to the Gilbert/Epoch 5 boundary (Saito, 1969; Berggren, 1973; Cita and Gartner, 1973; Berggren and Van Couvering, 1974; Ryan et al., 1974; Cita, 1975a,b, 1976, 1979; Saito et al., 1975; Van Couvering et al., 1976; Vincent, 1977b; Mazzei et al., 1979). This paleomagnetic boundary has often been used for convenience as a criterion to identify the Miocene/Pliocene boundary; however, the Miocene/Pliocene boundary is slightly younger than this magnetic reversal and falls about midway between the top of Epoch 5 and the Gilbert $\mathrm{C}$ event, at a level approximated by the FAD of Globorotalia tumida and LAD of Thalassiosira miocenica (Burckle, 1978). The FAD of Ceratolithus acutus occurs very slightly above the Miocene/Pliocene boundary at the Zanclean stratotype in Italy (Cita and Gartner, 1973; Gartner and
Bukry, 1974). In the three tropical sequences investigated here (Core RC12-66, Sites 157 and 158), these three paleontological events are close to each other and occur in the same sequence.

In Core RC12-66, the FAD of C. acutus at 1800 meters occurs at the base of carbonate event GI16; the LAD of T. miocenica at 1835 meters occurs within the transition between GI17 and GI18; and the FAD of $G$. tumida occurs at 1840 meters, near the top of GI18. The pronounced carbonate minimum GI17 is thus bracketed by the FAD of $C$. acutus above and the LAD of $T$. miocenica below. At Site 158, this carbonate event may therefore correspond to the carbonate minimum identified by Bode and Cronan (1973) at approximately 80 meters. A higher-amplitude low-carbonate excursion of 


\section{E. VINCENT}

Table 12. Calibration of biostratigraphic events to magnetostratigraphy (and to isotope stratigraphy for the upper Pleistocene).

\begin{tabular}{|c|c|c|c|c|c|}
\hline & & Paleontological Event ${ }^{1}$ & $\begin{array}{l}\text { Position in } \\
\text { Magnetostratigraphy } \\
\text { and Isotope } \\
\text { Stratigraphy }\end{array}$ & $\begin{array}{l}\text { Approximate } \\
\text { Age } \\
(\mathrm{m} . \mathrm{y} .)^{2}\end{array}$ & References \\
\hline 1 & B & Emiliania huxleyi $(\mathrm{N})$ & $\left\{\begin{array}{l}\text { Upper Brunhes } \\
\text { Upper isotopic Stage } 8\end{array}\right.$ & 0.27 & Thierstein et al. (1977) \\
\hline 2 & Col & llosphaera sp. A $\rightarrow$ Buccinosphaera invaginata $(\mathrm{R})$ & Upper Brunhes & 0.30 & Johnson and Knoll (1975) \\
\hline 3 & $\mathrm{~T}$ & Axoprunum angelinum (R) & $\left\{\begin{array}{l}\text { Middle Brunhes } \\
\text { Lowermost isotopic Stage } 11\end{array}\right.$ & 0.44 & $\begin{array}{l}\text { Hays and Shackleton (1976), } \\
\text { Morley and Shackleton (1978) }\end{array}$ \\
\hline 4 & $\mathrm{~T}$ & Pseudoemiliania lacunosa $(\mathrm{N})$ & $\left\{\begin{array}{l}\text { Middle Brunhes } \\
\text { Middle isotopic Stage } 12\end{array}\right.$ & 0.47 & Thierstein et al. (1977) \\
\hline 5 & B & Collosphaera tuberosa $(\mathrm{R})$ & Middle Brunhes & 0.53 & Johnson and Knoll (1975) \\
\hline 6 & B & Collosphaera sp. A (R) & Lower Brunhes & 0.64 & Johnson and Knoll (1975) \\
\hline 7 & $\mathrm{~T}$ & Globorotalia tosaensis (F) & Lower Brunhes & & Thompson (1976) \\
\hline 8 & $\mathrm{~T}$ & Nitzschia reinholdii (D) & Lower Brunhes & 0.65 & Burckle (1977) \\
\hline 9 & $\mathrm{~T}$ & Mesocena elliptica $(\mathrm{S})$ & $\begin{array}{l}\text { Middle of reversed interval } \\
\text { between Jaramillo and } \\
\text { Brunhes }\end{array}$ & 0.82 & Burckle (1977) \\
\hline 10 & $\mathrm{~T}$ & Eucyrtidium matuyamai (R) & Base Jaramillo & 0.9 & Hays (1970) \\
\hline 11 & $\mathrm{~T}$ & Anthocyrtidium angulare (R) & Just below base Jaramillo & 1.02 & Johnson and Knoll (1975) \\
\hline 12 & $\mathrm{~T}$ & Lamprocyrtis neoheteroporos ( $\mathrm{R}$ ) & $\begin{array}{l}\text { Upper reversed interval } \\
\text { between Jaramillo and } \\
\text { Olduvai }\end{array}$ & 1.10 & Johnson and Knoll (1975) \\
\hline 13 & B & Mesocena elliptica (S) & $\begin{array}{l}\text { Upper reversed interval } \\
\text { between Jaramillo and } \\
\text { Olduvai }\end{array}$ & 1.3 & Burckle (1977) \\
\hline 14 & The & eocorythium vetulum $\rightarrow T$. trachelium $(\mathrm{R})$ & $\begin{array}{l}\text { Lower reversed interval } \\
\text { between Jaramillo and } \\
\text { Olduvai }\end{array}$ & 1.42 & Johnson and Knoll (1975) \\
\hline 15 & $\mathrm{~T}$ & Rhizosolenia praebergonii s.I. (D) & $\begin{array}{l}\text { Lower reversed interval } \\
\text { between Jaramillo and } \\
\text { Brunhes }\end{array}$ & 1.64 & Burckle (1977) \\
\hline 16 & $\mathrm{~T}$ & Pterocanium prismatium (R) & Just above top Olduvai & 1.65 & Theyer et al. (1978) \\
\hline 17 & $\mathrm{~T}$ & Discoaster brouweri $(\mathrm{N})$ & Within Olduvai & 1.75 & Gartner (1973), Haq et al. (1977) \\
\hline 18 & B & Pseudoeunotia doliolus (D) & Lower Olduvai & 1.8 & Burckle (1977), Burckle and Trainer (1979) \\
\hline 19 & B & Eucyrtidium matuyamai (R) & Near base Olduvai & 1.85 & Hays (1970) \\
\hline 20 & $\mathrm{~T}$ & Lamprocyrtis heteroporos ( $\mathrm{R})$ & Near base Olduvai & 1.85 & Hays $(1970)$ \\
\hline 21 & $\mathrm{~T}$ & Eucyrtidium calvertense $(\mathrm{R})$ & Near base Olduvai & 1.88 & Hays (1970); Casey and Reynolds (1980) \\
\hline 22 & B & Globorotalia truncatulinoides (F) & Just below Olduvai & 1.9 & Saito et al. (1975) \\
\hline 23 & $\mathrm{~T}$ & Discoaster surculus (N) & Just below Olduvai & 2.05 & Gartner (1973) \\
\hline 24 & $\mathrm{~T}$ & Thalassiosira convexa (D) & $\begin{array}{l}\text { Midway between Gauss/ } \\
\text { Matuyama boundary and } \\
\text { base Olduvai }\end{array}$ & 2.26 & Burckle and Trainer (1979) \\
\hline 25 & $\mathrm{~T}$ & Reticulofenestra pseudoumbilica $(\mathrm{N})$ & Uppermost Gauss & 2.5 & Gartner (1973) \\
\hline 26 & $\mathrm{~T}$ & Nitzschia jouseae (D) & $\begin{array}{l}\text { Middle of normal upper } \\
\text { Gauss }\end{array}$ & 2.67 & Burckle and Trainer (1979) \\
\hline 27 & $\mathrm{~T}$ & Stichocorys peregrina $(\mathrm{R})$ & $\begin{array}{l}\text { Middle of normal upper } \\
\text { Gauss }\end{array}$ & 2.67 & Saito et al. (1975), Theyer et al. (1978) \\
\hline 28 & B & Rhizosolenia praebergonii (D) & $\begin{array}{l}\text { Between Kaena and } \\
\text { Mammoth }\end{array}$ & 3.0 & Burckle and Trainer (1979) \\
\hline 29 & $\mathrm{~T}$ & Globoquadrina altispira (F) & $\begin{array}{l}\text { Between Kaena and } \\
\text { Mammoth }\end{array}$ & 3.0 & Hays et al. (1969) \\
\hline 30 & $T$ & Sphaeroidinellopsis spp. (F) & Top Mammoth & 3.08 & Hays et al. (1969), Saito et al. (1975) \\
\hline 31 & B & Globorotalia tosaensis (F) & Just below base Mammoth & 3.2 & Hays et al. (1969) \\
\hline 32 & $\mathrm{~T}$ & Globorotalia margaritae (F) & Gilbert/Gauss boundary & 3.41 & Hays et al. (1969), Saito et al. (1975) \\
\hline 33 & $\mathrm{~T}$ & Ceratolithus tricorniculatus $(\mathrm{N})$ & Upper reversed Gilbert & 3.6 & Gartner (1973) \\
\hline 34 & $\mathrm{~T}$ & Ommatartus penultimus (R) & $\begin{array}{l}\text { Middle of upper reversed } \\
\text { Gilbert }\end{array}$ & 3.69 & Theyer et al. (1978) \\
\hline 35 & $\mathrm{~T}$ & "Globigerina" nepenthes (F) & Top A event of Gilbert & 3.8 & Hays et al. (1969), Saito et al. (1975) \\
\hline 36 & B & Discoaster asymmetricus $(\mathrm{N})$ & Base A event of Gilbert & 3.95 & Gartner (1973) \\
\hline 37 & B & Lamprocyrtis heteroporos $(\mathrm{R})$ & Just below B event of Gilbert & 4.3 & Casey and Reynolds (1980) \\
\hline 38 & B & Nitzschia jouseae (D) & Upper C event of Gilbert & 4.46 & $\begin{array}{l}\text { Burckle and Opdyke (1977), Burckle } \\
\text { (1978) }\end{array}$ \\
\hline 39 & B & Ceratolithus rugosus (D) & Within $C$ event of Gilbert & 4.56 & Gartner (1973) \\
\hline 40 & B & Coscinodiscus nodulifer var. cyclopus (D) & Base $\mathrm{C}$ event of Gilbert & 4.71 & Burckle (pers. comm.) \\
\hline 41 & B & Pterocanium prismatium $(\mathbf{R})$ & $\begin{array}{l}\text { Upper part of lower reversed } \\
\text { Gilbert }\end{array}$ & 4.8 & Theyer et al. (1978) \\
\hline 42 & B & Sphaeroidinella dehiscens $(\mathrm{F})$ & $\begin{array}{l}\text { Middle of lower reversed } \\
\text { Gilbert }\end{array}$ & 4.9 & Saito et al. (1975) \\
\hline 43 & B & Ceratolithus acutus $(\mathrm{N})$ & $\begin{array}{l}\text { Middle of lower reversed } \\
\text { Gilbert }\end{array}$ & 4.9 & Gartner (1973) \\
\hline 44 & $\mathrm{~T}$ & Thalassiosira miocenica (D) & Lower reversed Gilbert & 4.92 & Burckle (1978) \\
\hline 45 & $T$ & Dictyocha navicula $(\mathrm{S})$ & Lower reversed Gilbert & 4.95 & Burckle (pers. comm.) \\
\hline 46 & B & Globorotalia tumida (F) & Lower reversed Gilbert & 5.1 & Saito et al. (1975) \\
\hline 47 & $\mathrm{~T}$ & Globoquadrina dehiscens $(\mathrm{F})$ & Lowermost Gilbert & 5.2 & Saito et al. (1975) \\
\hline 48 & $\mathrm{~T}$ & Asterolampra acutiloba (D) & Top Epoch 5 & 5.26 & Burckle (1978) \\
\hline
\end{tabular}




\begin{tabular}{|c|c|c|c|c|c|}
\hline & & Paleontological Event ${ }^{1}$ & $\begin{array}{c}\text { Position in } \\
\text { Magnetostratigraphy } \\
\text { and Isotope } \\
\text { Stratigraphy }\end{array}$ & $\begin{array}{l}\text { Approximate } \\
\text { Age } \\
\text { (m.y. })^{2}\end{array}$ & References \\
\hline 49 & B & Dictyocha navicula (S) & Upper Epoch 5 & 5.3 & Burckle (pers. comm.) \\
\hline 50 & $\mathrm{~T}$ & Nitzschia miocenica (D) & Top A event of Epoch 5 & 5.43 & Burckle (1978) \\
\hline 51 & $\mathrm{~T}$ & Discoaster quinqueramus (N) & Upper A event of Epoch 5 & 5.46 & Gartner (1973) \\
\hline 52 & $\mathrm{~T}$ & Nitzschia miocenica var. elongata (D) & $\begin{array}{l}\text { Middle of A event of } \\
\text { Epoch } 5\end{array}$ & 5.5 & Burckle (pers. comm.) \\
\hline 53 & B & Globorotalia margaritae (F) & Lower A event of Epoch 5 & 5.55 & Saito et al. (1975) \\
\hline 54 & B & Pulleniatina primalis $(\mathrm{F})$ & Lower normal Epoch 5 & 5.6 & Saito et al. (1975) \\
\hline 55 & $\mathrm{~T}$ & Thalassiosira praeconvexa (D) & $\begin{array}{l}\text { Middle of lower normal } \\
\text { Epoch } 5\end{array}$ & 5.65 & Burckle (1978) \\
\hline 56 & $\mathrm{~T}$ & Cussia praepalacea (D) & Upper Epoch 6 & & Burckle (pers. comm.) \\
\hline 57 & B & Thalassiosira convexa var. aspinosa (D) & Upper Epoch 6 & 5.85 & Burckle (1978) \\
\hline 58 & B & Thalassiosira miocenica (D) & Upper Epoch 6 & 5.95 & Burckle (1978) \\
\hline 59 & B & Thalassiosira praeconvexa (D) & Middle Epoch 6 & 6.20 & Burckle (1978) \\
\hline 60 & B & Nitzschia miocenica var. elongata (D) & Middle Epoch 6 & 6.2 & Burckle (pers. comm.) \\
\hline 61 & & och 6 Carbon Shift & Middle Epoch 6 & 6.2 & Keigwin and Shackieton (1980) \\
\hline 62 & B & Stichocorys peregrina $(\mathrm{R})$ & Middle Epoch 6 & 6.25 & Theyer et al. (1978) \\
\hline 63 & B & Niızschia reinholdii (D) & Lower Epoch 6 & 6.46 & Burckle (1978) \\
\hline 64 & B & Nitzschia miocenica (D) & Middle Epoch 7 & 7.12 & Burckle (1978) \\
\hline 65 & $\mathrm{~T}$ & Cussia palacea (D) & Middle Epoch 7 & 7.18 & Burckle (1978) \\
\hline 66 & $\mathrm{~T}$ & Thalassiosira burckliana (D) & Lower Epoch 7 & 7.3 & Burckle (1978) \\
\hline 67 & $\mathrm{~T}$ & Coscinodiscus yabei $(=C$. plicatus $)$ (D) & Middle Epoch 8 & 8.2 & Burckle (1978) \\
\hline 68 & B & Thalassiosira burckliana (D) & Uppermost Epoch 9 & 8.6 & Burckle (1978) \\
\hline 69 & $\mathrm{~T}$ & Ommatartus hughesi (D) & Uppermost Epoch 9 & 8.63 & Theyer et al. (1978) \\
\hline 70 & $\mathrm{~T}$ & Ommatartus penultimus $(\mathrm{R})$ & Uppermost Epoch 9 & 8.63 & Theyer et al. (1978) \\
\hline 71 & $\mathrm{~T}$ & Cannartus petterssoni $(\mathrm{R})$ & Mididle Epoch 9 & 9.23 & Theyer et al. (1978) \\
\hline 72 & $\mathrm{~T}$ & Coscinodiscus vetustissimus var. javanicus (D) & Upper Epoch 10 & 10.1 & Burckle (1978) \\
\hline 73 & B & Neogloboquadrina acostaensis (F) & Middle Epoch 10 & 10.4 & Ryan et al. (1974) \\
\hline 74 & $\mathrm{~T}$ & Discoaster hamatus $(\mathrm{N})$ & Middle Epoch 10 & 10.5 & Ryan et al. (1974) \\
\hline 75 & B & Coscinodiscus vetustissimus var. javanicus (D) & Lower Epoch 10 & 10.6 & Burckle (1978) \\
\hline 76 & B & Acrobotrys tritubus (R) & Lower Epoch 10 & 10.9 & Theyer et al. (1978) \\
\hline 77 & B & Ommatartus antepenultimus ( $\mathrm{R})$ & Uppermost Epoch 11 & 11.2 & Theyer et al. (1978) \\
\hline 78 & B & Ommatartus hughesi $(\mathrm{R})$ & Uppermost Epoch 11 & 11.2 & Theyer et al. (1978) \\
\hline 79 & $\bar{T}$ & Stichocorys wolfii (R) & Upper Epoch 11 & 11.3 & Theyer et al. (1978) \\
\hline 80 & $\mathrm{~T}$ & Cyrtocapsella cornuta (R) & Middle Epoch 11 & 11.4 & Theyer et al. (1978) \\
\hline 81 & $\mathrm{~T}$ & Dorcadospyris alata $(\mathrm{R})$ & Middle Epoch 11 & 11.4 & Theyer et al. (1978) \\
\hline 82 & B & Cannartus petterssoni (R) & Middle Epoch 11 & 11.5 & Theyer et al. (1978) \\
\hline 83 & $\mathrm{~T}$ & Cyrtocapsella tetrapera (R) & Lower Epoch 11 & 11.7 & Theyer et al. (1978) \\
\hline 84 & $\mathrm{~T}$ & Turborotalia mayeri $(\mathrm{F})$ & Lower Epoch 11 & 11.7 & Ryan et al. (1974) \\
\hline 85 & B & Discoaster hamatus (N) & Lower Epoch 12 & 12.3 & Ryan et al. (1974) \\
\hline 86 & B & "Globigerina"' nepenthes (F) & Lower Epoch 12 & 12.4 & Ryan et al. (1974) \\
\hline 87 & B & Catinaster coalitus $(\mathrm{N})$ & Lower Epoch 12 & 12.45 & Ryan et al. (1974) \\
\hline
\end{tabular}

$1 \mathrm{~T}=$ top; $\mathrm{B}=$ bottom; $(\mathrm{R})=$ radiolarian; $(\mathrm{D})=$ diatom; $(\mathrm{S})=$ silicoflagellate; $(\mathrm{N})=$ calcareous nannofossil; $(\mathrm{F})=$ planktonic foraminifer.

2 Ages given here are not those published by the various authors; they were revised to follow Mankinen and Dalrymple's (1979) paleomagnetic time scale.

very short duration may have been missed in the data of these authors. I disagree with Dunn and Moore (1981), who place GI17 at Site 158 at about 93 meters, well below the LAD of $T$. miocenica and the FAD of $G$. tumida.

At Site 157, there is a pronounced carbonate minimum at 300 meters, which, as already mentioned, was correlated by Kaneps (1973b) to minimum GI17 in RC12-66. However, on the basis of the occurrence of the FAD of $C$. acutus and the LAD of T. miocenica at 316 and 325 meters, respectively, at Site 157, this pronounced carbonate minimum appears to be younger than minimum GI17 of RC12-66. The FAD of $G$. tumida at about 336 meters at Site 157 (Table 9) is taken from Keigwin's (1976) data. Kaneps (1973a), however, reported the first occurrence of this species at a higher level (at $305 \mathrm{~m}$, above the FAD of C. acutus). It is probable that the level reported by Kaneps (1973a) does not represent the level of evolutionary appearance of $G$. tumida. According to this author's data, this species oc- curs sporadically in the bottom of its range and does not overlap with its ancestor G. plesiotumida, which last occurs at 345 meters. Keigwin (1976) does not report the occurrence of $G$. plesiotumida. The discrepancy between Kaneps' (1973a) and Keigwin's (1976) data reflects the difficulty in drawing taxonomic boundaries within the $G$. plesiotumida-tumida lineage.

Below the carbonate event GI10-GI11-GI12 in the Gilbert C, there are in the lower Gilbert many more fluctuations at Site 157 than in Core RC12-66. The sedimentation rate at Site 157 is much higher than in Core RC12-66 (Fig. 8), but sampling intervals represent roughly similar time intervals for both sequences ( $\sim 20,000$ years). Kaneps (1973b) labelled almost every peak and trough of Site 157 curve within that interval and named five events (events " $q$ " to " $u$ " according to his terminology) below the double maximum GI10GI11-GI12 ("n-o-p" in Kaneps' terminology), where Dunn and Moore (1981) identify only two events (GI13 and GI14). The lower part of the carbonate stratigraphy 
Table 13. Carbonate events identified at DSDP Site 310.

\begin{tabular}{|c|c|c|c|}
\hline \multirow[b]{2}{*}{$\begin{array}{l}\text { Carbonate } \\
\text { Event }\end{array}$} & \multicolumn{2}{|c|}{ Position in Cores } & \multirow[b]{2}{*}{$\underset{(\%)}{\mathrm{CaCO}_{3}}$} \\
\hline & Sample & $\begin{array}{l}\text { Sub-bottom } \\
\text { Depth } \\
\text { (m) }\end{array}$ & \\
\hline $\mathrm{B} 10$ & $1-2,129-131 \mathrm{~cm}$ & 2.79 & 54.2 \\
\hline B11 & $1-3,58-60 \mathrm{~cm}$ & 3.58 & 28.0 \\
\hline M1 & $2-4,34-36 \mathrm{~cm}$ & 9.84 & 57.9 \\
\hline M7 & $3-3,54-56 \mathrm{~cm}$ & 18.04 & 37.0 \\
\hline M9 & $3-4,110-112 \mathrm{~cm}$ & 20.10 & 60.1 \\
\hline M11 & $3-5,141-143 \mathrm{~cm}$ & 21.91 & 53.7 \\
\hline M17 & $\begin{array}{l}\text { Between } 3-6,146-148 \mathrm{~cm} \\
\text { and } 4-1,61-63 \mathrm{~cm}\end{array}$ & $23.46-24.61$ & $<66.2$ \\
\hline M21 & $4-4,110-112 \mathrm{~cm}$ & 29.60 & 50.1 \\
\hline GU3 & $\begin{array}{l}\text { Between } 5-6,132-134 \mathrm{~cm} \\
\text { and } 6-1,53-55 \mathrm{~cm}\end{array}$ & $42.32-43.53$ & $<69.6$ \\
\hline GII & $6-4,14-16 \mathrm{~cm}$ & 47.64 & 53.6 \\
\hline GI9 & $7-1,128-130 \mathrm{~cm}$ & 53.78 & 43.7 \\
\hline GI10 & $7-2,69-71 \mathrm{~cm}$ & 54.69 & 82.1 \\
\hline GI11 & $7-2,129-131 \mathrm{~cm}$ & 55.29 & 67.1 \\
\hline GI12 & $7-3,12-14 \mathrm{~cm}$ & 55.62 & 87.7 \\
\hline GI13 & $7-3,42-44 \mathrm{~cm}$ & 55.92 & 68.6 \\
\hline GI19 & $7-4,17-18 \mathrm{~cm}$ & 57.17 & 44.5 \\
\hline $5 \mathrm{~d}$ & $7-4,140-142 \mathrm{~cm}$ & 58.40 & 84.8 \\
\hline $6 \mathrm{e}$ & $8-1,77-79 \mathrm{~cm}$ & 62.77 & 64.6 \\
\hline $6 \mathrm{e}$ & $8-3,46-48 \mathrm{~cm}$ & 65.46 & 36.8 \\
\hline $6 \mathrm{~h}$ & $8-4,41-43 \mathrm{~cm}$ & 66.91 & 85.1 \\
\hline $6 \mathrm{i}$ & $8-4,68-70 \mathrm{~cm}$ & 67.18 & 79.1 \\
\hline $6 j$ & $8-4,101-103 \mathrm{~cm}$ & 67.51 & 85.4 \\
\hline $6 \mathrm{k}$ & $8-4,131-133 \mathrm{~cm}$ & 67.81 & 79.2 \\
\hline $7 \mathrm{~b}$ & $8-5,10-12 \mathrm{~cm}$ & 68.10 & 91.4 \\
\hline $7 e$ & $8-5,103-105 \mathrm{~cm}$ & 69.03 & 44.0 \\
\hline $8 b-8 d$ & $\begin{array}{l}9-1,12-14 \mathrm{~cm} \text { to } 9-1, \\
103-105 \mathrm{~cm}\end{array}$ & $71.62-72.53$ & $88.8-91.8$ \\
\hline $9 e$ & $9-3,45-47 \mathrm{~cm}$ & 74.95 & 63.9 \\
\hline Mid-Epoch-10 Minimum & $9-4,13-15 \mathrm{~cm}$ & 76.13 & 61.0 \\
\hline Upper-Epoch-11 Minimum & $9-6,18-20 \mathrm{~cm}$ & 79.18 & 33.7 \\
\hline
\end{tabular}

at Site 157 below GI10-GI11-GI12 is not interpreted here (Figs. 4 and 7), because of the lack of carbonate data below 300 meters.

Comparisons among the various carbonate stratigraphies considered here thus cannot be made for the interval spanning the Miocene/Pliocene boundary. At Site 158, the condensed state of the Pliocene makes interpretation of the carbonate stratigraphy above the top of Epoch 5 (marked by the LAD of A. acutiloba) uncertain. At Site 310, a hiatus spans the Miocene/Pliocene boundary, which curtails the stratigraphic ranges of C. acutus, G. tumida and T. miocenica (the FADs of the two former species and the LAD of the latter occur simultaneously at the level of the unconformity). The Miocene/Pliocene boundary probably falls between carbonate events GI18 and GI19. The Mediterranean carbonate stratigraphy at Site 132 shows a pronounced carbonate minimum about 10 meters above the lithologic break marking the top of the evaporite (Ryan, Hsu, et al., 1973). This abrupt lithologic break, which marks the termination of the Mediterranean salinity crisis and the re-establishment of open marine conditions in this basin, has been identified with the Miocene/Pliocene boundary (Cita, 1973, 1976, 1979; Ryan et al., 1974; Cita and Ryan, 1979). Kaneps (1973b) correlated this carbonate minimum with the low-carbonate peak GI17 of RC12-66 (event " $x$ " in Kaneps' terminology), and the underlying carbonate maximum, just above the top of the evaporite, with maximum GI18 of RC12-66 (event " $y$ " in Kaneps' terminology).

\section{Miocene Correlations}

At Site 310 , the discontinuity in the sedimentary sequence at the Miocene/Pliocene boundary renders difficult the identification of the low-carbonate troughs directly below GI13. The pronounced carbonate minimum at 57.2 meters, between the unconformity and the LAD of $A$. acutiloba (marking the Gilbert/Epoch 5 boundary) probably corresponds to GI19 in the lowermost Gilbert.

In Core $\mathrm{RC12}-66$, the small carbonate minimum $5 \mathrm{a}$ in the uppermost Epoch 5 series is bracketed by the LAD of $A$. acutiloba and the FAD of $D$. navicula. At Site 158, the LAD of A. acutiloba at 100 meters identifies the top of Epoch 5, and the FAD of D. navicula at about 102 meters allows identification of carbonate event $5 \mathrm{a}$.

In Core RC12-66, the pronounced carbonate minimum $5 \mathrm{c}$ overlies an interval of high carbonate content in which carbonate event $5 \mathrm{~d}$ coincides with the LAD of $N$. miocenica at the top of the reversed magnetic event of Epoch 5. The LAD of $N$. miocenica at Sites 158 and 310 allows the placement of this paleomagnetic reversal at these two sites at 110 and 59.6 meters, respectively. At Site 310 , a carbonate minimum at about 58 meters approximates the FAD of $D$. navicula and cannot be assigned with certainty to either $5 \mathrm{a}$ or $5 \mathrm{c}$, but the high-carbonate interval between 58.4 and 59.6 meters can be identified as $5 \mathrm{~d}$.

The carbonate curve of RC12-66 shows a downwarddecreasing trend from maximum $5 \mathrm{~d}$ to the low-carbonate interval $5 \mathrm{i}-6 \mathrm{a}$. Carbonate minimum $5 \mathrm{i}$ occurs just above the FAD of Pulleniatina primalis and the LAD of Thalassiossira praeconvexa in lower Epoch 5, and carbonate minimum $6 \mathrm{a}$ occurs just above the LAD of Cussia praepalacea and the FAD of Thalassiosira convexa var. aspinosa in uppermost Epoch 6. At Site 158 , the occurrences of the FAD of $P$. primalis and LAD of $T$. praeconvexa at 119 and 120 meters, respectively, and the simultaneous occurrence of the LAD of $C$. praepalacea and FAD of $T$. convexa var. aspinosa at 123 meters, allow the placement of the Epoch 5/ Epoch 6 boundary between these two levels. At this site, as in $\mathrm{RC12}-66$, the carbonate curve shows a trend of downward-decreasing carbonate content from the LAD of $N$. miocenica down to the FAD of $T$. convexa var. aspinosa, but specific carbonate events identified in RC12-66 are not recognized.

Carbonate minimum $5 \mathrm{e}$ in $\mathrm{RC} 12-66$ coincides with the LAD of Nitzchia miocenica var. elongata. At Site 158 , this diatom event at 118 meters does not correlate with a distinct carbonate event (Dunn and Moore [1981], however, assigned a small carbonate minimum at 118.8 meters to event 5e). I disagree with Dunn and Moore's (1981) assignment of the distinct low-carbonate peak at 126 meters at Site 158 to event $6 \mathrm{a}$, because this low-carbonate peak lies below the LAD of $C$. praepalacea and the FAD of $T$. convexa var. aspinosa, whereas event $6 \mathrm{a}$ in RC12-66 occurs above these two diatom datums. The 126-meter low-carbonate peak at Site 158 coincides with 
the FAD of T. miocenica, and thus correlates with carbonate event $6 \mathrm{c}$ of RC12-66. Carbonate minimum $6 \mathrm{a}$, which is bracketed in RC12-66 by the LAD of $T$. praeconvexa and FAD of $C$. praepalacea, is not present at Site 158 between these two diatom events.

At Site 310 , the highly condensed state of the sedimentary sequence between the LADs of $N$. miocenica and $T$. praeconvexa (only $4 \mathrm{~cm}$ apart), and the presence of an unrecovered interval below, in the lower part of Core 7, preclude study of the carbonate stratigraphy for the middle and lower Epoch 5 and uppermost Epoch 6.

The trend of downward-decreasing carbonate content extends at Site 158 down to the pronounced lowcarbonate peak $6 \mathrm{e}$. The Epoch 6 Carbon Shift occurs at this site just below this low-carbonate peak, in association with the LAD of Stychocorys peregrina and the FAD of Nitzchia miocenica var. elongata. The FAD of $T$. praeconvexa occurs slightly above. These three siliceous-fossil datums and this isotopic event also occur close to each other in Core RC12-66, in the lower part of the younger normal event of Epoch 6. In this core, however, the overlying carbonate minimum $6 \mathrm{e}$ is not very pronounced.

At Site 310, the occurrence of both the LAD of $S$. peregrina and FAD of $T$. praeconvexa, together with the Epoch 6 Carbon Shift, identifies the pronounced lowcarbonate peak just above these events at 65.5 meters as carbonate minimum $6 \mathrm{e}$. It is one of the most extreme low-carbonate excursions of the entire Neogene.

Below low-carbonate peak $6 \mathrm{e}$, there is a trend of downward-increasing carbonate content down to the high-carbonate interval $6 \mathrm{~h}-7 \mathrm{~b}$ in Cores RC12-66 and RC12-65 and at Site 158. At Site 310, the high-carbonate interval between 66.9 and 68.1 meters can be assigned to the interval $6 \mathrm{~h}-7 \mathrm{~b}$. Small peaks and troughs within that interval appear to correlate among Site 310, $\mathrm{RC} 12-66$, and $\mathrm{RC} 12-65$, allowing identification at Site 310 of carbonate events $6 \mathrm{~h}, 6 \mathrm{i}, 6 \mathrm{j}$, and $6 \mathrm{k}$. The Epoch 6/Epoch 7 boundary thus can be placed at Site 310 at about 68 meters, between carbonate events $6 \mathrm{k}(67.8 \mathrm{~m})$ and $7 \mathrm{~b}(68.1 \mathrm{~m})$. Calcium carbonate data obtained by Dunn and Moore (1981) at Site 158 also permit the recognition of carbonate events $6 \mathrm{i}, 6 \mathrm{j}$, and $6 \mathrm{k}$ at this site, allowing placement of the Epoch 6/Epoch 7 boundary in this sequence at about 148.5 meters (between events $6 \mathrm{k}$ at $147.8 \mathrm{~m}$ and $7 \mathrm{~b}$ at $149 \mathrm{~m}$ ).

In the upper Epoch 7 series, the FAD of Nitzschia miocenica occurs slightly above the LAD of Cussia palacea in both RC12-65 and Site 158 just below carbonate event $7 \mathrm{~b}$. The first occurrence of $N$. micoenica at Site 310 apparently does not correspond to the level of evolutionary appearance of this species, which first occurs here stratigraphically too high within Epoch 6.

The sequence of siliceous events, which consists (from top to bottom) of the Ommatartus hughesi LAD, Thalassiosira burckliana LAD, Coscinodiscus yabei LAD, and $T$. burckliana FAD, occurs in both RC12-65 and Site 158. It allows correlation of the Epochs 7 and 8 carbonate events of RC12-65 with those of Site 158, and placement of the Epoch 7/Epoch 8 boundary at the latter site near 170 meters (between events $7 \mathrm{~g}$ at $165.8 \mathrm{~m}$ and $8 \mathrm{~b}$ at $172.5 \mathrm{~m}$ ). There is a discrepancy between the magnetostratigraphic position of some of these siliceous datums in RC12-65 and that given by Burckle (1978) and Theyer et al. (1978). The T. burckliana FAD occurs in RC12-65 in lower Epoch 8, whereas Burckle (1978) reports this diatom datum in uppermost Epoch 9. The O. hughesi LAD occurs in RC12-65 in lower Epoch 7, whereas Theyer et al. (1978) place this radiolarian datum in upper Epoch 9, coincident with the Ommatartus penultimus $\mathrm{FAD}, O$. penultimus is not reported in RC12-65; at Site 158 it first occurs just below the $O$. hughesi LAD.

At Site 310, the LAD of $O$. hughesi occurs simultaneously with the FAD of $O$. penultimus at 69.25 meters, just a few centimeters above the LAD of $T$. burckliana, allowing assignment of the pronounced low-carbonate peak at 69 meters to carbonate minimum $7 \mathrm{e}$. These biostratigraphic datums are the lowest Neogene siliceous events available at Site 310 .

The discrepancy between the paleomagnetic age assigned to the $O$. hughesi $\mathrm{LAD}$ and $O$. penultimus $\mathrm{FAD}$ by Theyer et al. (1978) and the younger paleomagnetic age of these radiolarian events in RC12-65 and Site 158 may explain at Site 310 the significant offset of these two datums from the average accumulation-rate curve constructed by Vincent (this volume). A similar discrepancy occurs between the paleomagnetic age given by Theyer et al. (1978) for the Cannartus petterssoni LAD and the Acrobotrys tritubus FAD, in mid Epoch 9 and low Epoch 10, respectively, and the younger paleomagnetic age of these two radiolarian events at Site 158 in mid-Epoch 8 (between the $C$. yabei LAD and the $T$. burckliana FAD).

Below the pronounced carbonate minimum $7 \mathrm{e}$, the carbonate stratigraphy in both $\mathrm{RC} 12-65$ and Site 158 consists of an increase in carbonate content down to the high-carbonate interval $8 \mathrm{~b}-8 \mathrm{~d}$, and a decrease in carbonate content down to carbonate minimum $9 \mathrm{e}$ at the base of Epoch 9. Below that level, the remainder of Core RC12-65 is almost free of carbonate, whereas at Site 158 the decreasing trend extends down to an extreme carbonate minimum at 212 meters, which falls slightly below the FAD of Neogloboquadrina acostaensis and the LAD of Dicoaster hamatus. Paleomagnetic calibration of both these calcareous events to the middle of Epoch 10 (Ryan et al., 1974) allows placement of this pronounced low-carbonate peak in mid-Epoch 10 and the Epoch 9/Epoch 10 boundary at Site 158 at about 198 meters (just below carbonate event $9 \mathrm{e}$ and above the N. acostaensis FAD).

At Site 310, the co-occurrence of the FAD of N. acostaensis and the LAD of D. hamatus at about 75.5 meters, between two carbonate minima, suggests that the overlying carbonate minimum at 75 meters corresponds to $9 \mathrm{e}$, and the underlying one at 76.1 meters to the "Mid-Epoch 10" carbonate minimum. The high-carbonate interval between 71.6 and 72.5 meters appears to correspond to the high carbonate interval $8 \mathrm{~b}-8 \mathrm{~d}$. The Epoch 9/Epoch 10 boundary falls at Site 310 near 75 meters. It is not possible, however, to pinpoint at this site the positions of the Epoch 7/Epoch 8 boundary be- 
tween 69.3 meters ( $T$. burckliana LAD) and 71.6 meters (top of the interval 8b-8d), and of the Epoch 8/Epoch 9 boundary between 72.5 meters (bottom of the interval $8 \mathrm{~b}-8 \mathrm{~d}$ ) and 75 meters (even 9e).

Below the mid-Epoch 10 low-carbonate peak, there is at Site 158 a trend of increasing carbonate content down to the base of the sequence, with several pronounced low carbonate excursions. The excursion at about 240 meters falls into the lowermost upper Miocene, that at about 257 meters into the upper middle Miocene.

The upper/middle Miocene boundary (Serravalian/ Tortonian boundary) has been shown to fall within the Dicoaster hamatus nannofossil zone (NN9) and foraminifer Zone N15, at approximately the level of the Ommatartus antepenultimus/Cannartus petterssoni radiolarian zonal boundary (Berggren and Van Couvering, 1974; Theyer and Hammond, 1974; Van Couvering and Berggren, 1977; Theyer et al, 1978). These authors place this level within uppermost Epoch 11, whereas Ryan et al. (1974), followed by Berggren and Van Couvering (1978), place it within lower Epoch 11. At Site 158 the simultaneous occurrence of the FADs of $O$. antepenultimus and $O$. hughesi (marking the $C$. petterssoni/O. antepenultimus zonal boundary) at 244 meters allows placement of the upper/middle Miocene boundary at this level, it falls in the lowermost $D$. hamatus Zone and is coincident with the base of Zone N15 (at the level of appearance of Turborotalia siakensis and T. mayeri). Following the Theyer et al. (1978) paleomagnetic interpretation, the Epoch 10/Epoch 11 boundary thus can be drawn slightly above that level.

The occurrence of the Stichocorys wolfii LAD at Site 158 at 248 meters, slightly below the FADs of $O$. antepenultimus and $O$. hughesi, is in agreement with the radiolarian sequence reported in uppermost Epoch 11 by Theyer et al. (1978). Below that level, the radiolarian events down to 296 meters (through Core 34 ) all are indicative of Epoch 11 according to Theyer et al.'s (1978) scheme. Thus, it is probable that the base of the sedimentary sequence above basaltic basement at Site 158 belongs to Epoch 11, or is not much older. This paleomagnetic age assignment, however, is younger than that derived from calcareous fossils. The base of the sequence belongs to the Discoaster exilis nannofossil zone of Bukry (= NN6 + NN7) and foraminifer Zone N13, an interval which according to Ryan et al. (1974) is older than Epoch 11 (encompassing lower Epoch 12, Epoch 13, and upper Epoch 14). The FADs of D. hamatus and of Catinaster coalitus occur at Site 158 at about 245 meters and 249 meters, respectively, delimiting the $C$. coalitus Zone (NN8) between these two datums. This nannofossil zone thus falls here in upper Epoch 11, according to the paleomagnetic age based on radiolarians, whereas Ryan et al. (1974) correlate this nannofossil zone to lower Epoch 12.

The $C$. coalitus Zone at Site 158 lies between the two distinct carbonate peaks which occur at 240 and 257 meters, respectively. The lower of these two peaks is bracketed by the FAD of $C$. coalitus above and the LAD of Globorotalia lenguaensis below, and falls in upper Epoch 11 according to the paleomagnetic age based on radiolarians (Theyer et al., 1978). This low-carbonate peak can be identified at Site 310 at 79.2 meters, between these two calcareous datum events.

The base of the Neogene sedimentary sequence at Site 310 , which unconformably overlies Oligocene sediments, belongs to the $D$. exilis nannofossil zone of Bukry (= NN6 + NN7) and to foraminifer Zone N14. It thus appears to be younger than basal Neogene sediments at Site 158, and probably falls within Epoch 11 . (It was placed in a lower magnetostratigraphic position by Vincent (this volume), who followed the age assignment of Ryan et al. (1974) for calcareous nannofossil Zone NN8).

\section{SEDIMENTATION RATES}

Average accumulation rates for various series at all sites studied are given in Figure 8, using the paleomagnetic time scale of Mankinen and Dalrymple (1979). Sedimentation rates are reduced in the piston cores, which are all located below 4400 meters water depths. They are higher at Site 310 , at a water depth of 3500 meters, and much higher at Sites 157 and 158, at water depths of 2500 and 1900 meters, respectively, both located in an area of high productivity.

Average accumulation rates for the entire Quaternary (from the base of the Olduvai to the recent, that is, slightly more than the Quaternary) is about 6 to 7 $\mathrm{m} / \mathrm{m} . \mathrm{y} .\left(=\mathrm{mm} / 10^{3} \mathrm{yr}\right)$ in Cores V24-58 and RC11-209, and about 3 to $4 \mathrm{~m} / \mathrm{m}$.y. in the deeper Cores V24-59 and $\mathrm{RC} 12-66$, whereas it is approximately 13 and $53 \mathrm{~m} / \mathrm{m} . \mathrm{y}$. at Sites 310 and 157 , respectively. The sedimentation rate is not constant and appears to be higher for intervals of higher carbonate content. The interval between the base of the Jaramillo and the base of the Brunhes accumulated at a slightly reduced rate compared to that of the overlying Brunhes (except at both Sites 310 and 157, where the uppermost Brunhes is missing), but accumulated at all sites roughly twice as fast as the underlying interval between the base of the Jaramillo and the base of the Olduvai.

The average accumulation rate for the upper Pliocene and upper half of the lower Pliocene, from the base of the Olduvai to the base of the Gilbert B, is similar to that of the entire Pleistocene. It is approximately 2 and $3 \mathrm{~m} / \mathrm{m} . \mathrm{y}$. in Cores V24-59 and $\mathrm{RC} 12-66$, respectively; $13 \mathrm{~m} / \mathrm{m} . y$. at Site 310 ; and $55 \mathrm{~m} / \mathrm{m} . \mathrm{y}$. at Site 157 . Variations in accumulation rates within that interval appear to correlate with average calcium carbonate concentrations. In piston Cores V24-59 and RC12-66, the average accumulation rate for the lower Matuyama below the Olduvai is higher than that of the underlying Gauss, which is in turn lower than that of the upper Gilbert. In contrast to these piston cores the Gauss accumulated faster than overlying and underlying sediments at both DSDP Sites 157 and 310.

The lower Gilbert, below the Gilbert B, accumulated in Core $\mathrm{RC12}-66$ at a slightly higher average rate $(4$ $\mathrm{m} / \mathrm{m}$.y.) than that of the overlying Pliocene, whereas at Site 157 it accumulated more rapidly $(92 \mathrm{~m} / \mathrm{m} . \mathrm{y}$.$) , and$ at Site 310 much more slowly (about $4 \mathrm{~m} / \mathrm{m}$.y.). In both RC12-66 and Site 310, the lowermost Gilbert, below the 
Gilbert $\mathrm{C}$ event, accumulated more slowly than the overlying sequence between the Gilbert $\mathrm{B}$ and the base of the Gilbert C; this is the interval which in Core RC12-66 encompasses the low-carbonate interval GI15-GI17 and at Site 310 includes a hiatus.

The uppermost Miocene equivalent to Epoch 5 and upper Epoch 6 above the Epoch 6 Carbon Shift accumulated in both cores RC12-66 and Site 310 more rapidly than overlying sediments, with an average rate of about 8 and $10 \mathrm{~m} / \mathrm{m}$.y., respectively. This interval accumulated also at a higher average rate than that obtained for the underlying remainder of the Miocene, which is at Site 310 about $2 \mathrm{~m} / \mathrm{m} . \mathrm{y}$.

Within the interval encompassing Epochs 7, 8, and 9, the Epoch 8 sequence, which corresponds to a high-carbonate interval, accumulated in both RC12-65 and Site 158 at a higher rate than Epochs 7 and 9, of lesser carbonate content. Epoch 10, however, which corresponds at Site 158 to an interval of significantly lower carbonate concentration, accumulated at a higher rate than overlying intervals.

Variations in accumulation rates within magnetic series show the severe limitation of the use of linear extrapolation performed on the basis of an assumed uniform accumulation rate. Ages of paleontological datums are usually derived by this method, as were those of isotopic stage boundaries (Shackleton and Opdyke, 1973). As pointed out by Shackleton and Opdyke (1976) these age estimates are at this time the best available, but it should be kept in mind that they cannot be regarded as definitive. I emphasize again that absolute ages assigned to paleontological datums (Table 12) are approximate, and that sedimentation-rate curves constructed from these ages (such as the curve in fig. 7 of Vincent, this volume) should be considered with these restrictions in mind. These curves usually do not show short-term fluctuations, and their slopes give only an approximate estimate of average accumulation rates. Despite these restrictions, such curves are useful for deriving general trends in regional sediment-accumulation history.

\section{FORAMINIFER PRESERVATION}

Quantitative studies of foraminifer preservation, using the "solution index" method (based on the species composition of a foraminifer assemblage), on Pleistocene sediments in Indo-Pacific tropical cores have yielded correlations between carbonate content and preservation, with poorer preservation within low-carbonate intervals (Oba, 1969; Luz and Shackleton, 1975; Valencia, 1977; Volat et al., 1980). The relationship is more or less well defined, depending on the degree of carbonate dissolution (Adelseck, 1977).

Carbonate curves are not always correlatable to changes in the preservation signals, because instead of being dependent on only one factor (dissolution intensity), they are also dependent on supply and dilution by non-carbonate material. In Pleistocene cores with high carbonate content, it is difficult to identify discernible trends in the fluctuations. Bielak and Briskin (1978) did not see a pattern in their data. In Cores V28-238 and
V28-239, from the western equatorial Pacific, Thompson and Saito (1974) were unable to discern trends in the carbonate content, whereas solution indexes in these same cores clearly show dissolution cycles correlatable to the carbonate cycles defined by Hays et al. (1969) in other equatorial Pacific cores (Thompson and Saito, 1974; Thompson, 1976; Thompson and Sciarrillo, 1978). Foraminifer solution cycles in these two cores correlate with the oxygen-isotope record (Thompson, 1976; Shackleton and Opdyke, 1973, 1976). A comparison of the two signals shows that preservation is best during a rapid rise of sea level and worse during a fall, "preservation spikes" coinciding with deglaciation events (see fig. 12 in Berger and Vincent, 1981).

"Solution index" data are not available for the sequences considered here. States of foraminifer preservation, however, have been reported by various authors. At Sites 310 and 466, on Hess Rise, foraminifer faunas at the top of these two sedimentary sequences are "moderately" well preserved, the ratio of fragments of planktonic foraminifers to unfragmented planktonicforaminifer tests being approximately 1 and 0.7 , respectively, and benthic species comprising 9 and $11 \%$ of the foraminifer assemblage, respectively (Vincent, this volume). These two parameters reflect the amount of dissolution undergone by the foraminifer fauna, and their values indicate here a significant amount of dissolution. Parker (1971) suggested that solution has occurred in a calcareous ooze where the foraminifer fauna contains more than $1 \%$ of benthic species (benthic forms being much more resistant than the planktonic ones). These two parameters have not been calculated down-core. Visual estimates, however, allow recognition of overall trends in preservation changes (a larger sampling interval for foraminifer study than for carbonate-content analyses prevents detailed correlation between specific carbonate peaks and troughs and preservation).

At both Sites 310 and 466, the upper Pleistocene interval with a minimum $\mathrm{CaCO}_{3}$ content (corresponding to low-carbonate event $\mathrm{B} 11$ and the overlying interval) contains a foraminifer fauna more poorly preserved than those in the remainder of the Pleistocene. No such overall correlation between lower carbonate content and poorer foraminifer preservation exists in Pliocene sediments. At both sites, the lower Pliocene contains the most poorly preserved fauna of the entire Plio-Pleistocene sequence, and also the highest $\mathrm{CaCO}_{3}$ content (Vincent, this volume).

In contrast, Pliocene intervals of low carbonate content in the deeper Cores V24-59 and RC12-66 contain more poorly preserved foraminifer faunas than carbonate-rich intervals (Hays et al., 1969; Saito et al., 1975). These authors report evidence of corrosion of foraminifer tests below 8.60 meters in Core V24-59, and in Core RC12-66 in the intervals from 5.0 to 7.0 meters (encompassing M11-M17), from 9.0 to 15.0 meters (encompassing GU3-GU15), and from 17.0 to 19.0 meters (encompassing GI15-GI17). Within these intervals, the early disappearance of a number of calcareous microfossils was ascribed by Hays et al. (1969), Gartner (1973), and Saito et al. (1975) to the elimination of these 
E. VINCENT

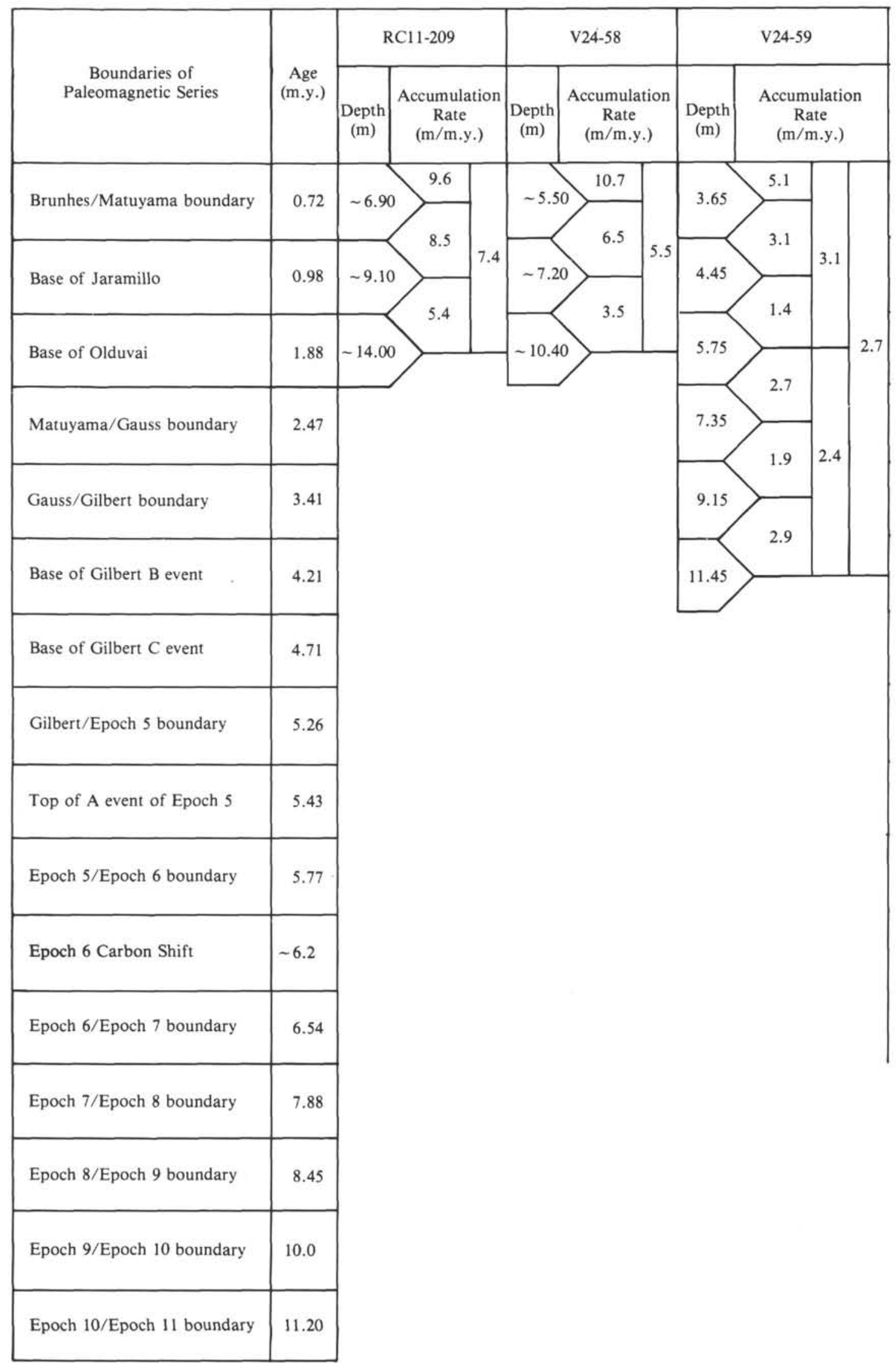

Figure 8. Sediment accumulation rates. 


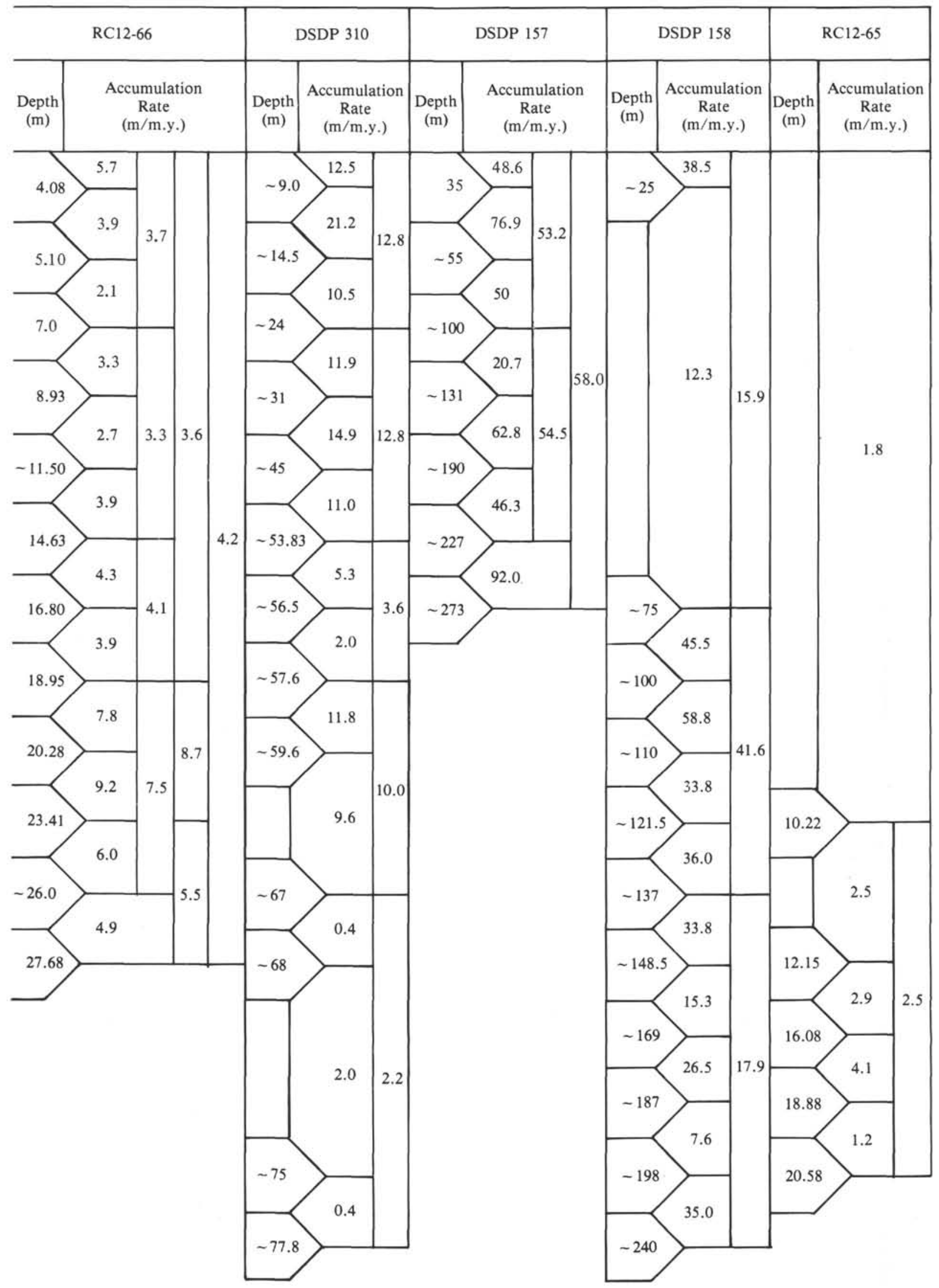

Figure 8. (Continued). 
taxa by dissolution (compare Tables 6 and 7 with Table 12). In both cores, Hays et al. (1969) and Saito et al. (1975) noted that foraminifer dissolution was particularly pronounced in the intervals between 8.70 and 10.70 meters in V24-59, and between 9.50 and 12.50 meters in $\mathrm{RC} 12-66$, which in both cores corresponds to the interval of minimum carbonate content GU3-GI1.

In Miocene sediments at Site 310, Keller (1980) recognized three intervals of increased dissolution marked by an increase in fragmented tests. These intervals are as follows: (1) from the upper part of Section 4 to the middle part of Section 5 of Core 8; (2) throughout Section 1 of Core 9, and (3) throughout Sections 5 and 6 of Core 9. The first two of these intervals occur in the upper Miocene and correspond to high-carbonate intervals $6 \mathrm{~h}-7 \mathrm{~b}$ and $7 \mathrm{~b}-8 \mathrm{~d}$, respectively, whereas the third occurs in the middle Miocene and encompasses the pronounced upper-Epoch 11 low-carbonate peak.

At Sites 157 and 158 in the Panama Basin, benthicto-planktonic ratios and fragments-to-whole-tests planktonic ratios have been calculated by Keigwin (1976) throughout the Pleistocene to upper Miocene sequences (again, the difference in sampling density for foraminifer study and carbonate-content analyses precludes detailed correlation of carbonate peaks and troughs with foraminifer preservation changes). Actual values are not published in Keigwin's (1976) paper, but can be derived from his plots. Because of the scale given by this author, however, small-scale variations are not apparent. At both sites, variations of these two ratios are minor throughout the Plio-Pleistocene, but dramatic excursions occur in the Miocene, with a considerable increase in fragmentation and in the proportion of benthic foraminifers. Such a dissolution spike occurs at about 150 meters at Site 158 and corresponds to the pronounced low-carbonate peak $7 \mathrm{e}$.

Another dissolution spike occurs at Site 158 at about 200 meters, which correlates with the pronounced midEpoch 10 low-carbonate peak. Keigwin's (1976) foraminifer-preservation data do not extend below 200 meters at Site 158. Kaneps (1973a), however, reports poorly preserved foraminifer faunas below that level, down to about 240 meters (Cores 24-27), an interval which he correlates with a similar middle Miocene dissolution interval at nearby Site 155 (encompassing at both sites the D. hamatus Zone).

\section{DISCUSSION AND PALEOCEANOGRAPHY}

From the foregoing detailed stratigraphic analysis, it is clear that specific carbonate events are identifiable in all the investigated Neogene records, demonstrating the ocean-wide nature of these events. It is obviously necessary, however, to have independent biostratigraphic and(or) magnetostratigraphic control to correlate carbonate events between various areas. It is clear that interpretation of carbonate stratigraphy without good biostratigraphic control would be futile, since peaks and troughs follow each other in a non-unique fashion. The lack of such control would easily lead to misenditification or misplacement of individual carbonate events.

Some of the pronounced low-carbonate excursions, or "'dissolution spikes," have very short duration and easily may be missed with inadequate sampling density. Spike $5 \mathrm{c}$ at Site 158, for example, was missed with Bode and Cronan (1973) data, but was identified by Dunn and Moore (1981) with a closer sampling interval (Fig. 5). Plio-Pleistocene carbonate stratigraphies of Sites 310 and 466 are compared in Figure 3. These two proximate sites on Hess Rise have a similar sedimentary history, with approximately the same accumulation rate (Vincent, this volume). Virtually none of the specific carbonate events identified at Site 310 , with a sampling interval equivalent to a time span of about 20,000 years, are detectable on the carbonate curve obtained at Site 466 , with a sampling interval equivalent to 50,000 to 70,000 years. The carbonate curve obtained at Site 463, to the south in the Mid-Pacific Mountains, with a sampling interval equivalent to about 450,000 years, shows only gentle undulations (Vincent, this volume).

It is of prime importance to determine if carbonate signals, especially major excursions and characteristic sequences, may serve as chronostratigraphic markers, because stable-isotope signals appear to become less useful in older Neogene sediments than in the upper Pleistocene, and biostratigraphic correlation is often difficult between locations underlying different water masses.

Diachronism of paleontological events is evident from a comparison of the sequences of first and last occurrences of species at various sites (Tables 4-11) with the sequence of their levels of evolutionary appearances and extinctions (Table 12). The diachronism results either from ecologically induced late appearances or early disappearances of species, or from elimination of taxa by dissolution. (In some instances the scarcity of species and/or taxonomic ambiguity introduce difficulty in the identification of datum levels.) Calcareous planktonic faunas and floras appear to be of limited value for "direct" biostratigraphic correlation of the Hess Rise sequence with those of the equatorial regions (at least for a large part of the Neogene), whereas siliceous fossils, especially diatoms, are more useful.

High-resolution stratigraphy and precise correlations can be obtained only with full integration of biostratigraphy from various fossil groups and independent systems such as paleomagnetostratigraphy and chemostratigraphy. Once a chemostratigraphic signal is shown to be global, it can be used for testing the synchroneity of paleontological datums in various regions. Such tests have been performed for example by Thierstein et al. (1977) and Haq et al. (1980) to establish the synchroneity of calcareous-nannofossil events.

\section{Long-Term Carbonate Cycles}

Long-term cycles are superimposed on the short-term carbonate fluctuations in the equatorial Pacific sequences. Some of these long-term cycles are apparent in the carbonate stratigraphy at Site 310 , especially in the Pleistocene and Miocene, but are not detected in the Pliocene.

The carbonate stratigraphy of the piston cores shows three long-term cycles in the Pleistocene, superimposed on the 75,000 - to 100,000 year cycles. The two younger cycles have a duration of roughly $0.5 \mathrm{~m} . \mathrm{y}$, and the older 
one about 1.0 m.y. The older cycle from the base of the Olduvai through the Jaramillo includes a low-carbonate interval from troughs M17 to M11, overlain by an interval of higher carbonate content from peaks M10 to M4. The next-younger cycle from the Jaramillo to the middle Brunhes includes a low-carbonate interval from troughs $\mathrm{M} 3$ to $\mathrm{M} 1$, and a high-carbonate interval from peaks $\mathrm{B} 16$ to $\mathrm{B} 12$. The latter interval has the highest $\mathrm{CaCO}_{3}$ average concentration of the entire Pleistocene. The youngest cycle, which corresponds to the late Brunhes, has not yet been completed; it includes a low-carbonate interval from B11 to B5, followed by the high-carbonate peak B2.

Adelseck (1977) differentiated an additional 0.5-m.y. cycle superimposed on the older 1-m.y. cycle mentioned above (defined by low-carbonate interval M 17, highcarbonate interva! M15, and low-carbonate interval M13-M11). This author analyzed the Brunhes cycles in a number of equatorial Pacific cores and noted a change in sedimentological expression of these cycles as a function of depth.

Despite the uncertainties which remain in the identification of certain intervals of the Pleistocene carbonate stratigraphy at Site 310 , overall trends at this site allow the recognition of the three long-term cycles. The low-carbonate trough B11 in the youngest cycle has the lowest $\mathrm{CaCO}_{3}$ concentration of the entire Neogene section. The interval corresponding to the older cycle, from the Jaramillo through the Olduvai, accumulated in all piston cores, and at DSDP Sites 310 and 157, at a lower average rate than the remainder of the Pleistocene.

In the Pliocene of Core RC12-66, there are long-term cyclic fluctuations with a period on the order of $1.5 \mathrm{~m}$.y. These consist of intervals showing increasing carbonate down to maximum M20, decreasing carbonate down to minimum GU3, increasing carbonate down to maximum GI10-GI12, and decreasing carbonate down to minimum GI17. Such a trend is seen partly in the carbonate stratigraphy at Site 157, but is not seen at Site 310. At both these sites, the Gauss accumulated at an average rate higher than overlying and underlying sediments (Fig. 8). This series contains the highest $\mathrm{CaCO}_{3}$ average concentration of the entire Neogene at Site 310, whereas in Cores V24-59 and RC12-66 it corresponds to a low-carbonate interval which accumulated more slowly than overlying and underlying sediments.

In the upper Miocene, long-term cycles are superimposed on the short-term cycles which provide the basis for Dunn and Moore's (1981) nomenclature. From the carbonate stratigraphies of RC12-66 and RC12-65, Dunn and Moore (1981) recognized cycles with a period of the order of $1 \mathrm{~m} . y$. , defined by intervals of major carbonate minima (GI17-5c, 5i-6a, 7c-7e, and 9c-9e) and major carbonate maxima (5d-5f, $6 \mathrm{~h}-7 \mathrm{~b}$, and $8 \mathrm{~b}-8 \mathrm{~d})$. These authors consider the long-term oscillation superimposed on these cycles from minimum GI17 to maximum $6 \mathrm{~h}-7 \mathrm{~b}$ and minimum $9 \mathrm{e}$ as part of a longer-term cycle of a duration of over 2 m.y.

Such a long-term cycle, if present at all in Cores RC12-66 and RC12-65, is not apparent at Sites 310 and 158. Long-term cycles with a period on the order of 1 m.y., however, are apparent at these two sites. The three intervals of major carbonate maxima identified in the piston cores $(5 \mathrm{~d}-5 \mathrm{f}, 6 \mathrm{~h}-7 \mathrm{~b}$, and $8 \mathrm{~b}-8 \mathrm{~d})$ are distinct at Sites 158 and 310 . The intervals of major carbonate minima, however, do not all coincide with those of the piston cores. Below the major minimum $5 \mathrm{c}$, major carbonate minima at both Sites 158 and 310 are $6 \mathrm{e}, 7 \mathrm{e}$, "mid-Epoch 10," and "upper Epoch 11."' The time interval represented between these minima is on the order of $1 \mathrm{~m} . y$. , except for that between minima $7 \mathrm{e}$ and midEpoch 10, which is on the order of $3 \mathrm{~m} . \mathrm{y}$.

\section{Paleoceanography}

Oxygen-isotope studies of deep-sea cores have shown that late Pleistocene carbonate fluctuations in the equatorial Pacific are correlative with climatic oscillationsas originally postulated by Arrhenius (1952), glacial intervals corresponding to high-carbonate sediments. Arrhenius (1952) attributed these carbonate cycles to productivity fluctuations, whereas Olausson (1965), Broecker (1971), Berger (1973), Thompson and Saito (1974), and other studies of foraminifer preservation show that dissolution variations primarily account for the carbonate variations; increased interglacial dissolution being primarily responsible for the low-carbonate intervals between glacials. Productivity changes, however, are probably present within the dissolution cycles. Valencia (1977) suggested that dissolution effects are dominant in sediments from deeper water, and productivity effects dominant in sediments above the lysocline, a suggestion supported by Adelseck and Anderson's (1978) findings. The question of how significant productivity cycles are in determining glacial-interglacial sedimentary patterns in the equatorial Pacific thus remains.

Shackleton and Opdyke (1976) ascribed variations in coarse-fraction $(>180 \mu \mathrm{m})$ percentages in Core V28-239 to changes in dissolution intensity, and assigned them to the carbonate events defined by Hays et al. (1969). They show that the correlation between the isotopic signal and the "dissolution signal" extends down through the entire Pleistocene with an apparent phase shift between the two signals, the changes in preservation lagging behind those of oxygene-isotope composition. Such a "lead-lag" relationship had been reported previously in upper Pleistocene cores (Luz and Shackleton, 1975; Ninkovich and Shackleton, 1975; Pisias et al., 1975; Thompson, 1976; Moore et al., 1977).

The intensity of every glaciation was apparently of almost the same extent since Isotopic Stage 22, that is, throughout the interval from slightly after the Jaramillo to the present (Shackleton and Opdyke, 1973, 1976). Thus it cannot be implied that the interval of the Brunhes with the lowest $\mathrm{CaCO}_{3}$ average concentration (from carbonate event B5 through B11) corresponds to a period of less-intense glaciations, and the interval of the Brunhes with the highest $\mathrm{CaCO}_{3}$ average concentration (B12 through B16) to greatest glacial advances. Prior to Isotopic Stage 22, glacial extremes were significantly less intense than were those of the middle and late Pleistocene (Shackleton and Opdyke, 1976). Planktonic faunal and floral evidence, as well as the influx of ice- 
rafted detritus, show that a profound cooling starting about 0.8 m.y. ago between the Jaramillo and the Brunhes (the very time of Isotopic Stage 22) is recorded throughout the North Pacific and northeast Pacific margin (see references in Vincent, this volume). This pulse of intense cooling is recorded on Hess Rise at approximately 9 meters at Site 310 and 12 meters at Site 466 (Fig. 3). At the former site, it appears to coincide with greater oxygen-isotope excursions in the positive direction just above 10 meters (Fig. 2). At Site 157, the frequency and magnitude of $\delta^{18} \mathrm{O}$ oscillations increase above 46 meters (Fig. 4), suggesting more-pronounced Pleistocene glaciations above that level, in agreement with the stratigraphic position of carbonate event M3, which marks the onset of Isotopic Stage 22.

The coincidence of the pronounced dissolution spikes M3 and M1 with the start of intense cooling just above the Jaramillo is intriguing.

It has been suggested that this cooling marks the advent - of continental glaciation in temperate latitudes (Hays and Berggren, 1971). It is well known that continental glaciation in higher latitudes precedes this date. The onset of northern-hemisphere glaciation appears to have occurred about 3.1 to $3.0 \mathrm{~m}$.y. ago from evidence of glacial activity in Iceland (Rutten and Wensink, 1960; McDougall and Wensink, 1966), in the Sierra Nevada (Curry, 1966), and influx of ice-rafted material in the North Atlantic (Berggren, 1972; Poore, 1979). A major glaciation about 2.4 to $2.5 \mathrm{~m} . \mathrm{y}$. ago in New Zealand (Matthews and Curtis, 1966; Stipp et al., 1967) is recorded in the isotopic and faunal records of DSDP Site 284 in the southwest Pacific (Kennett and Vella, 1975; Shackleton and Kennet, 1975). Shackleton and Opdyke (1977) recognized these two major Pliocene glacial events in the benthic oxygen-isotope record of the equatorial Pacific (Core V28-179) as two distinct enrichments in ${ }^{18} \mathrm{O}$ just above the Gauss/Matuyama boundary $(\sim 3.1 \mathrm{~m} . \mathrm{y}$.$) , and in the mid-Gauss (\sim 2.4 \mathrm{~m} . \mathrm{y}$.$) , respec-$ tively. These two time horizons correspond in Cores V24-59 and RC12-66 to the pronounced dissolution spikes M21 and GU3. Two enrichments in ${ }^{18} \mathrm{O}$ correlative with M21 and GU3, respectively, are also seen in the benthic oxygen-isotope records of Core V24-59 (Vincent and Killingley, unpubl.) and of Sites 157 and 310 (Keigwin, 1979; Figs. 2 and 4).

The intense cooling corresponding to GU3 and to the simultaneous ${ }^{18} \mathrm{O}$ enrichment is recorded in planktonic foraminifers from Hess Rise at Site 310 (cold event C2 of Keller, 1978) and Site 466 (Fig. 3), as well as at other North Pacific drilling sites (Vincent, 1975, 1977a; Keller, 1979), and at Site 157, in the Panama Basin (Keigwin, 1976). At the latter site, an increase in the abundance of temperate-water planktonic foraminifers near 175 meters correlates with GU3. Parker (1967) reported increases in temperature-water species near the middle/upper Pliocene boundary in tropical Indo-Pacific cores, which she attributed to climatic decline. Another marked increase of temperate-water species occurs at about 130 meters at Site 157 (Keigwin, 1976), which correlates with M21. At Site 310, cold event C3 of Keller (1978), recorded between 24 and 28.5 meters (Fig. 3), appears to lag slightly behind M21.
Again, the co-occurrence of the pronounced dissolution spikes M21 and GU3 with climatic deterioration is striking and may be of worldwide significance.

In the Mediterranean carbonate stratigraphy at DSDP Site 132 (Ryan, Hsü, et al., 1973), a pronounced low-carbonate peak at about 63 meters has been identified as M21 by Kaneps (1973b). Carbonate event GU3 as identified by Kaneps at about 88 meters at this site, however, is stratigraphically higher than the 3.1-m.y. ${ }^{18} \mathrm{O}$ enrichment shown by Keigwin and Thunnell (1979) at about 105 meters, a discrepancy which may require re-evaluation of Kaneps' interpretation. At Site 397, in the North Atlantic, Shackleton and Cita (1979) recognized the two levels of distinct enrichment in ${ }^{18} \mathrm{O}$ of benthic foraminifers corresponding to these two time horizons. In Core V28-179, in the equatorial Pacific, the younger of these two oxygen-isotope events (the one just above the Gauss/Matuyama boundary) is associated with a major lightening trend in carbon-isotope composition (Shackleton and Opdyke, 1977). Shackleton and Cita (1979) found a similar marked carbon-isotope event in the same stratigraphic position at Site 397 in the North Atlantic and suggested that it resulted from a vegetational change at that time, when tropical forests disappeared from northern Europe (the time of the "Pliocene/Pleistocene boundary" of paleobotanists; Zagwign, 1974). A carbon-isotope lightening also is apparent in the benthic isotopic record at Site 157 at approximately 130 meters, correlative with the ${ }^{18} \mathrm{O}$ enrichment and dissolution spike M21 (Fig. 4).

Isotopic records for "preglacial", Pliocene (older than 3.1 m.y.) from various oceanic areas show that relatively stable, warm climates prevailed through most of the early Pliocene (Shackleton and Kennett, 1975; Shackleton and Opdyke, 1977; Keigwin and Thunnell, 1979; Shackleton and Cita, 1979). The $\delta^{18} \mathrm{O}$ variability in the lower Pliocene at Site 310 (Fig. 2) is mainly due to consistently higher values for Oridorsalis compared to those of Uvigerina, which calls for caution in interpretation because of differential fractionation between species (see Vincent et al., 1981).

At Site 157 , the downward lightening trend in $\delta^{18} \mathrm{O}$ in the lower Pliocene is interpreted by Keigwin (1979) as resulting from increased diagenetic effect with depth, evidenced by significant calcite overgrowth below 200 meters. The oxygen-isotope stratigraphy at this site below that level is thus of limited value for paleoceanographic interpretation.

A glaciation in the early Pliocene has been evidenced in high southern latitudes, particularly by a glacial advance in Patagonia (Mercer, 1976). A period of cooling in the earliest Pliocene is recorded in planktonic-foraminifer assemblages from North Pacific drilling sites (event C1 of Keller 1978, 1979, recorded between 52.5 and 54 meters at Site 310; see Fig. 3), as well as in those from tropical Sites 157 and 158. At these two sites, the earliest Pliocene cooling is recorded by a dramatic increase in cool- and temperate-waters planktonic foraminifers (Keigwin, 1976). At Site 157, this abrupt increase in cool fauna correlates with the 300-meter pronounced low-carbonate peak. The isotopic record is here obscured by diagenetic effects; however, a marked 
depletion in ${ }^{13} \mathrm{C}$ appears to occur at that level. At Site 158 , two peaks of abundance of cool fauna occur between 64 and 70 meters (the lowest of these two peaks may correspond to the pronounced low-carbonate peak at 70 meters). Within that interval there is a distinct ${ }^{18} \mathrm{O}$ positive excursion associated with a depletion in ${ }^{13} \mathrm{C}$.

In order to analyze with precision the synchroneity of isotopic and carbonate excursions of short duration, one needs to obtain isotopic and carbonate data from paired samples, as did Shackleton and Cita (1979) in their study of North Atlantic DSDP Site 397. In the lowest Pliocene sedimentary record at Site 397, there are, below 350 meters, high-frequency and high-amplitude oxygen-isotope and calcium carbonate fluctuations of short duration which covary, low-carbonate peaks coinciding with ${ }^{18} \mathrm{O}$ enrichment (Cita, 1979; Cita and Ryan, 1979; Cita and Spezzibottiani, 1979; Shackleton and Cita, 1979). This interval of high-frequency oxygen-isotope and carbonate-content oscillations extends down across the Miocene/Pliocene boundary and correlates with the latest part of the Mediterranean salinity crisis. It appears to correspond to the interval which, in the equatorial Pacific, encompasses the 300 -meter event of Site 157 and events GI15, GI17, GI19, and 5c and includes a hiatus at Site 310 . The low-carbonate peak GI17 may correspond at Site 397 to the excursion at 390 meters (Core 41) just above the Miocene/Pliocene boundary, within the Sphaeroidinellopsis Acme Zone of the Mediterranean (Cita, 1973). These oscillations are interpreted by Cita and Ryan (1979) as the response of the open ocean to the Mediterranean "salinity crisis," a hypothesis previously suggested by Ryan et al. (1974) on the basis of low-carbonate excursions in the sedimentary record of DSDP Site 62, in the equatorial Pacific. This is also the time of shallowest CCD in the equatorial Pacific, which, after rising throughout the late Miocene, dropped abruptly in the earliest Pliocene (van Andel et al., 1975; Berger, 1978).

The Epoch 6 Carbon Shift is not apparent in the isotopic record of North Atlantic DSDP Site 397 (Shackleton and Cita, 1979); however, the scarcity of carbonisotope data at this site below the level approximately coeval with the Epoch 6 Carbon Shift makes interpretation of the isotopic stratigraphy difficult. The stratigraphic level of the Epoch 6 Carbon Shift can be inferred at Site 397 in the lower part of Core 47, in the upper reversed interval of Epoch 6 (Hamilton, 1979), just below a coiling change in Neogloboquadrina acostaensis (Salvatorini and Cita, 1979). This coiling change is recorded in the equatorial Pacific (RC12-66 and Site 158) just above the carbon shift (Saito et al., 1975; Keigwin, 1979; Keigwin and Shackleton, 1980). In the North Pacific and equatorial Pacific, the Epoch 6 Carbon Shift occurs just below the pronounced carbonate minimum 6 e.

What may have caused such a carbon-isotope shift is by no means obvious. It has been discussed by various authors (Keigwin, 1979; Bender and Keigwin, 1979; Keigwin and Shackleton, 1980; Vincent et al., 1980; Berger and Vincent, in press; Berger et al., in press). No consensus has been reached.
The timing of this event is significant. It occurred at the time the Mediterranean entered its phase of partial isolation, that is, the earliest part of the younger reversed event of Epoch 6 (Ryan et al., 1974; Cita and Ryan, 1979). This isolation, which resulted in subsequent desiccation cycles and buildup of thick salt deposits (Ryan, Hsü, et al., 1973; Ryan et al., 1974; Hsü, Montadert, et al., 1978), was presumably due to a critical elevation of the entrance sill of the Mediterranean, produced by a glacio-eustatic lowering of sea level (Van Couvering et al., 1976; Adams et al., 1977).

Worldwide evidence of lowering of sea-level and climatic deterioration near the end of the Miocene is well documented (Bandy, 1966; Kennett, 1967, 1977; Kennett and Vella, 1975; Shackleton and Kennett, 1975; Berggren and Haq, 1976; Adams et al., 1977; Vail et al., 1977; Kennett et al., 1979; among others). An ${ }^{18} \mathrm{O}$ enrichment seen in the oxygen-isotope record at Sites 310 (at $67 \mathrm{~m})$ and $158(136-142 \mathrm{~m})$ suggests climatic deterioration at or just before the Epoch 6 Carbon Shift (although analyses performed on different species at these stratigraphic levels call for caution in interpretation). Vincent et al., (1980) have pointed out an apparent increase in the coherence and energy of the ${ }^{18} \mathrm{O}$ signal above the Epoch 6 Carbon Shift, which might be explained by climatic oscillations paralleling the Mediterranean desiccation cycles through albedo feedback in and around the Mediterranean, possibly amplified by ice-mass variations on Antarctica and variations in snow-field expansion in Arctic regions (Berger and Vincent, in press).

Among the many consequences of a drop in sea level, one which is thought important by Vincent et al. (1980) and Berger and Vincent (in press) in the production of the Epoch 6 Carbon Shift is the large-scale introduction, through surficial erosion of shelf sediments and continental soils, of ${ }^{12} \mathrm{C}$-rich organic matter. These authors also argue for other or additional explanations (which they do not claim to be exhaustive), such as changes in fertility pattern (suggested by increased isotopic fractionation between foraminifer species) and changes in deep circulation patterns (also invoked by Bender and Keigwin, 1979).

The marked increase in sedimentation rates after the Epoch 6 Carbon Shift in Core RC12-66 and Sites 158 and 310 (Fig. 8), as well as at other Indo-Pacific sites (Vincent, 1977b; Vincent et al., 1980), may result from increased erosion rates and increased fertility. Input of organic carbon (or blockage of output) should decrease the carbonate saturation of the ocean, and hence lead to increased dissolution of deep-sea carbonate, which might explain dissolution spike $6 \mathrm{e}$.

Following the build-up of a large ice cap in Antarctica in the middle Miocene (Savin et al., 1975; Shackleton and Kennett, 1975; Savin, 1977; Keigwin, 1979; Woodruff et al., 1981), a gradual cooling occurred in the late Miocene (see review in Kennett, 1977), particularly well documented in the faunal and isotopic records at DSDP Site 284, in the southwest Pacific (Kennett and Vella, 1975; Shackleton and Kennett, 1975; Kennett et al., 1979). The precise timing of the buildup of the Ant- 
arctic ice cap recently has been documented by Woodruff et al. (1981) from a detailed isotopic record from the western equatorial Pacific. These authors concluded that the transition from an unglaciated to glaciated world occurred between $16.5 \mathrm{~m}$.y. ago (early middle Miocene) and 13 m.y. ago (mid-middle Miocene; foraminifer Zone N13). The latter date is close to that of the base of the isotopic record at Site 158 above the chert.

The upward enrichment in ${ }^{18} \mathrm{O}$ throughout the middle Miocene and lowermost upper Miocene at Site 158 is interpeted by Keigwin (1979) to reflect the combined effects of growth of permanent ice associated with bottom-water temperature decrease and calcite diagenesis due to high in situ temperature. This interval is mainly a low-carbonate interval (with an average level of carbonate content about $20 \%$ lower than overlying upper Miocene), showing an overall trend of upward-decreasing carbonate content. Two pronounced low-carbonate excursions within that interval (in middle Epoch 10 and upper Epoch 11) are also seen on the carbonate record at Site 310 .

At Site 310, the benthic oxygen-isotope record shows an upward gradual ${ }^{18} \mathrm{O}$ enrichment of about $0.5 \%$ throughout the middle Miocene and lower upper Miocene, paralleled by an ${ }^{18} \mathrm{O}$ enrichment in the planktonic record, which suggests a cooling of surface water of a few degrees (Keigwin, 1979). The planktonic oxygenisotope record at Site 158 for the equivalent interval shows little change, which led Keigwin (1979) to conclude that the differing surface-water $\delta^{18} \mathrm{O}$ records at the two sites probably reflect surface-water cooling through the early late Miocene, at temperate latitude, with relatively constant temperature in the tropics. Supportive evidence is the early disappearance of the tropical planktonic foraminifer Globoquadrina dehiscens in the middle late Miocene at Site 310, whereas in the equatorial Pacific (Site 158 and Core RC12-66) this species ranges up to the latest Miocene. From changes in planktonicforaminifer assemblages, Keller (1980) distinguished several pulses of cooling, associated with increased dissolution, throughout the Miocene at Site 310.

At Site 158, dissolution spike 7e in the middle upper Miocene, at approximately 160 meters (marked by a pronounced low-carbonate excursion and a high fragments-to-planktonic ratio), is not associated with a noticeable change in the species composition of the planktonic-foraminifer assemblage (Keigwin, 1976). The benthic oxygen-isotope record, however, seems to indicate an enrichment in ${ }^{18} \mathrm{O}$ at that level (if only the Uvigerina record is taken into account; see Fig. 5). At Site 310, low-carbonate peak $7 \mathrm{e}$ occurs at the base of one of the intervals of dissolution and cooling identified by Keller (1980). This interval extends upward throughout the high-carbonate interval $6 \mathrm{~h}-7 \mathrm{~b}$. Another interval of "dissolution" and cooling is identified by Keller (1980) lower in the sequence, which corresponds to the highcarbonate interval $7 \mathrm{f}-8 \mathrm{~d}$.

\section{Geochemical Significance}

We have seen that carbonate records from various areas of the Pacific Ocean, in the equatorial belt of high organic productivity, from shallow depths on the ridges of the Panama Basin (where carbonate dissolution should be at a minimum) to great depths not far above the CCD (where carbonate dissolution is highly significant), as well as in the temperate area of the North $\mathrm{Pa}$ cific, show coherency. There are differences, however, in the character of individual records. Long-term carbonate cycles well defined in the deep equatorial Pacific cores are only partly present in the shallower sequences from the Panama Basin and Hess Rise. Such cycles are recognizable in the Pleistocene and Miocene at Site 310, but not in the Pliocene. Specific low-carbonate excursions (or "dissolution spikes") seen on the Pacific records occur in other areas under different oceanographic regimes, such as the North Atlantic and the Mediterranean, indicating that the mechanisms involved are wholeocean phenomena that are undoubtedly modified by local conditions.

That certain carbonate fluctuations and excursions correlate within and between basins-while of the utmost important for chronostratigraphy-does not necessarily imply that these correlations were produced by one or two master variables. From the detailed comparisons here attempted, it appears that a number of processes may be at work, producing a complex pattern of carbonate dissolution through time. At different times, especially when comparing glacial periods with more equable states, the mix of processes responsible for the dissolution patterns may vary greatly.

The ocean-geochemistry mechanisms producing carbonate fluctuations and excursions are still largely unknown. From an examination of the Pleistocene record, at least two processes have to be considered (Berger and Vincent, in press). The first mechanism, responsible for an overall correlation between oxygen-isotope and carbonate records, is presumably associated with quasiequilibrium states and changes in carbonate mass balance which accompany sea level changes. During times of high sea level, the enhanced precipitation of shelf carbonates would decrease available carbonate for the deep ocean, while during times of low sea level shelf carbonates would be exposed to erosion and be transferred to the deep sea. The fact, however, that preservation in the equatorial Pacific is best during a rapid rise of sea level and worst during a fall indicates that mass balance alone cannot explain the Pleistocene dissolution cycles. The second mechanism then, must be associated with temporary disequilibrium conditions, and hence transient changes in ocean chemistry.

The coincidence of dissolution spikes with coolingregression events in both Pleistocene and pre-Pleistocene records is significant. Berger and Vincent (1981) speculate that this coincidence signifies release of organic carbon to the ocean system from transient carbon reservoirs (shallow marine organic-rich sediments, marshes, swamps, soil, and forests). This mechanism is attractive because the resultant excess $\mathrm{CO}_{2}$ reacting with carbonate can readily produce a pronounced dissolution spike. If this suggestion is valid, the dissolution spikes should be associated with lightening in carbon isotopes. Evidence that this is the case in several instances has been presented above. 
Of course alternative (or additional) mechanisms must also be considered. A general increase in fertility of the ocean would raise the CCD (Broecker, 1974), and could produce a dissolution spike if temporary. Increased erosion and supply of phosphate from land could produce, for example, such a temporary increase.

These suggestions are no more than working hypotheses at this point. When we understand better the oceangeochemistry mechanisms producing carbonate fluctuations, we will also have a better understanding of the carbon-isotope record. Both records are signals stemming from the carbon cycle, and a close correspondence between the two can be expected.

\section{CONCLUSIONS}

Neogene carbonate deep-sea records from various regions under different oceanographic regimes show coherence over wide areas. Dissolution spikes are recognizable throughout the world ocean, and appear to be related to global changes in the chemistry of the ocean, linked to regression-cooling events. These provide chemostratigraphic signals of utmost importance for chronostratigraphic correlations.

Future studies of detailed carbonate stratigraphy will improve our understanding of geochemical processes which produce carbonate fluctuations, especially if combined with studies of other chemostratigraphic signals of global significance, such as the oxygen- and carbonisotope signals. Such studies will allow distinction of global, regional, and local components of stratigraphic signals. To attain such a goal, a full integration of biostratigraphy, magnetostratigraphy, and chemostratigraphy is necessary.

\section{ACKNOWLEDGMENTS}

I thank Lloyd H. Burckle and John A. Barron for making available to me unpublished data, and Wolfgang $\mathrm{H}$. Berger for stimulating discussions and for reviewing the manuscript. I acknowledge the helpful cooperation of William A. Coulbourn and also of the data-handling group at DSDP under Peter B. Woodbury in processing carbonate data. Listings of carbonate values for the piston cores were provided by Lamont-Doherty Geological Observatory. This research was supported by the National Science Foundation, Grant OCE 79. 19090 (CENOP).

\section{REFERENCES}

Adams, C. F., Benson, R. H., Kidd, R. B., et al., 1977. The Messinian salinity crisis and evidence of Late Miocene eustatic changes in the world ocean. Nature, 269:383-386.

Adelseck, C. G., Jr., 1977. Recent and late Pleistocene sediments from the eastern equatorial Pacific Ocean: Sedimentation and dissolution [Ph.D. dissert.]. University of California, San Diego.

Adelseck, C. G., Jr., and Anderson, T. F., 1978. The late Pleistocene record of productivity fluctuations in the eastern equatorial $\mathrm{Pa}$ cific Ocean. Geology, 6:388-391.

Arrhenius, G., 1952. Sediment cores from the east Pacific. Repts. Swedish Deep-Sea Exp., 1947-1948, 5:1-202.

Bandy, O. L., 1966. Faunal evidence of Miocene-to-Recent paleoclimatology in Antarctic. Bull. Am. Assoc. Petrol. Geol., 50: 643-644.

Bender, M. L., and Keigwin, L. D., Jr., 1979. Speculations about the upper Miocene change in abyssal Pacific dissolved bicarbonate $\delta^{13}$ C. Earth Planet. Sci. Lett., 45:383-393.

Berger, W. H., 1973. Deep-sea carbonates: Pleistocene dissolution cycles. J. Foraminiferal Res., 3:187-195.
1977. Deep-sea carbonate and the deglaciation preservation spike in pteropods and foraminifera. Nature, 269:301-304.

1978. Sedimentation of deep-sea carbonate: maps and models of variations and fluctuations. J. Foraminiferal Res., $8: 286-302$.

Berger, W. H., and Vincent, E., in press. Chemostratigraphy and biostratigraphic correlation: exercises in systemic stratigraphy. Oceanologica Acta,

Berger, W. H., Vincent, E., and Thierstein, H. R., in press. The deepsea record: major steps in Cenozoic ocean evolution. Soc. Econ. Paleontol. Mineral., Spec. Publ.

Berger, W. H., and Winterer, E. L., 1974, Plate stratigraphy and the fluctuating carbonate line. In Hsu, K. J., and Jenkyns, H. C. (Eds.), Pelagic Sediments on Land and Under the Sea: Spec. Publ. Internat. Assoc. Sedimentol., 1:11-48.

Berggren, W. A., 1972. Cenozoic biostratigraphy and paleobiogeography of the North Atlantic. In Laughton, A. S., Berggren, W. A., et al., Init. Repts. DSDP, 12: Washington (U.S. Govt. Printing Office), 965-1001.

1973. The Pliocene time-scale: calibration of planktonic foraminiferal and calcareous nannoplankton zones. Nature, 243: 391-397.

Berggren, W. A., and Haq, B., 1976. The Andalusian Stage (late Miocene): biostratigraphy, biochronology and paleoecology. $\mathrm{Pa}$ leogeogr., Palaeoclimatol., Palaeoecol., 20:67-129.

Berggren, W. A., and Van Couvering, J. A., 1974. The late Neogene: Biostratigraphy, geochronology and paleoclimatology of the last 15 million years in marine and continental sequences. Palaeogeogr., Palaeoclimatol., Palaeoecol., 16:1-216.

1978. Biochronology. Am. Assoc. Petrol. Geol. Stud. Geol., 6:39-55.

Bode, G. W., and Cronan, D. S., 1973. Carbon and carbonate analyses, Leg 16, Deep Sea Drilling Project. In van Andel, Tj. H., Heath, G. R., et al., Init. Repts. DSDP, 16: Washington (U.S. Govt. Printing Office), 521-528.

Bielak, L. E., and Briskin, M., 1978. Pleistocene biostratigraphy, chronostratigraphy and paleocirculation of the Southeast Pacific Central Water Core RC11-220. Mar. Micropaleont., 3:51-94.

Broecker, W. S., 1971. Calcite accumulation rates and glacial to interglacial changes in oceanic mixing. In Turekian, K. K. (Ed.), The Late Cenozoic Glacial Ages: New Haven (Yale Univ. Press), pp. 239-265.

, 1974. Chemical Oceanography: New York (Harcourt, Brace, Jovanovich).

Bukry, D., 1973. Coccolith stratigraphy, eastern equatorial Pacific, Leg 16, Deep Sea Drilling Project. In van Andel,Tj. H., Heath, G. R., et al., Init. Repts. DSDP, 16: Washington (U.S. Govt. Printing Office), 653-711.

, 1975. Coccolith and silicoflagellate stratigraphy, Northwestern Pacific Ocean, Deep Sea Drilling Project, Leg 32. In Larson, R. L., Moberly, R., et al., Init. Repts. DSDP, 32: Washington (U.S. Govt. Printing Office), 677-702.

1978. Cenozoic silicoflagellate and coccolith stratigraphy, southeastern Atlantic Ocean, Deep Sea Drilling Project Leg 40. In Lancelot, Y., Seibold, E., et al., Init. Repts. DSDP, 40: Washington (U.S. Govt. Printing Office), 635-643.

Burckle, L. H.,1972. Late Cenozoic planktonic diatom zones from the Eastern Equatorial Pacific. Beih. Nova Hedwigia, 39:217-246.

1977. Pliocene and Pleistocene diatom datum levels from the equatorial Pacific. Quat. Res., 7:330-340.

1978. Early Miocene to Pliocene diatom datum levels for the equatorial Pacific. Second Working Group Meeting, Proceedings, IGCP Project 114, Biostratigraphic Datum-Planes of the Pacific Neogene. Geological Research and Development Centre, Bandung, Indonesia, pp. 25-44.

1979. Validation of middle Pliocene to Pleistocene paleomagnetic reversal record using diatom and silicoflagellate datum levels. In von Rad, U., Ryan, W. B. F., et al., Init. Reports DSDP, 47, Pt. 1: Washington (U.S. Govt. Printing Office), 479-480.

Burckle, L. H., and Opdyke, N. D., 1977. Late Neogene diatom correlations in the circum-Pacific. Proceedings of the First International Congress on Pacific Neogene Stratigraphy, Tokyo 1976, pp. 255-284. 
Burckle, L. H., and Trainer, J., 1979. Middle and late Pliocene diatom datum levels from the central Pacific. Micropaleont., 25:281-293.

Casey, R. E., and Reynolds, R. A., 1980. Late Neogene radiolarian biostratigraphy related to magnetostratigraphy and paleoceanography with suggested cosmopolitan radiolarian datums. Cushman Found. Foraminiferal Res. Spec. Publ., 19:287-300.

Cita, M. B., 1973. Pliocene biostratigraphy and chronostratigraphy. In Ryan, W. B. F., Hsü, K. J., et al., Init. Repts. DSDP, 13, Pt. 2: Washington (U.S. Govt. Printing Office), 1343-1379.

1975a. The Miocene/Pliocene boundary: history and definition. In Saito, T., and Burckle, L. H. (Eds.), Late Neogene Epoch Boundaries: New York (Micropaleont. Press), pp. 1-30. 1975b. Planktonic foraminiferal biozonation of the Mediterranean Pliocene deep sea record. A revision. Riv. Ital. Paleont., Milano, 81:527-544.

1976. Planktonic foraminiferal biostratigraphy of the Mediterranean Neogene. In Takayanagi, Y., and Saito, T., (Eds.), Progress in Micropaleontology, Selected Papers in Honor of Prof. $K$. Asano: New York (Micropaleont. Press), pp. 47-68.

1979. Lacustrine and hypersaline deposits in the desiccated Mediterranean and their bearing on paleoenvironment and paleoecology. In Talwani, M. T., Hay, W., and Ryan, W. B. F. (Eds.), Deep Drilling Results in the Atlantic Ocean: Continental Margins and Paleoenvironment: Washington (Am. Geophys. Union), pp. 402-419.

Cita, M. B., and Gartner, S. Jr., 1973. The stratotype Zanclean: foraminiferal and nannofossil biostratigraphy. Riv. Ital. Paleont., Milano, 79:503-588.

Cita, M. B., and Ryan, W. B. F., 1979. Late Neogene environmental evolution. In von Rad, U., Ryan, W. B. F., et al., Init. Repts. $D S D P, 47$, Pt. 1: Washington (U.S. Govt. Printing Office), 447459.

Cita, M. B., and Spezzibottiani, G., 1979. Late Neogene paleoenvironment studies on carbonate content, grain sizes, and dissolution, Cores 1-57 (DSDP Site 397). In von Rad, U., Ryan, W. B. F., et al., Init. Repts. DSDP, 47, Pt. 1: Washington (U.S. Govt. Printing Office), 671-682.

Curry, R. R., 1966. Glaciation about 3,000,000 years ago in the Sierra Nevada. Science, 154:770-771.

Dinkelman, M. G., 1973. Radiolarian stratigraphy: Leg 16, Deep Sea Drilling Project. In van Andel, Tj. H., Heath, G. R., et al., Init. Repts. DSDP, 16: Washington (U.S. Govt. Printing Office), 747-813.

Dunn, D. A., 1980. Revised techniques for quantitative calcium carbonate analysis using the "Karbonat-Bombe," and comparisons to other quantitative carbonate analysis methods. J. Sediment. Petrol., 50:631-637.

Dunn, D. A., and Moore, T. C., Jr., 1981. Late Miocene-Pliocene (magnetic epoch 9-Gilbert magnetic epoch) calcium carbonate stratigraphy of the Equatorial Pacific Ocean. Geol. Soc. Am. Bull., 92:408-451.

Ewing, J., Ewing, M., Aitken, T., et al., 1968. North Pacific sediment layers measured by seismic profiling. In Knopoff, L., Drake, C. L., and Hart, P. J. (Eds.), The Crust and Upper Mantle of the Pacific Area: Am. Geophys. Union, Geophys. Monogr., 12: 147-186.

Foreman, P. H., 1975. Radiolaria from the North Pacific, Deep Sea Drilling Project, Leg 32. In Larson, R. L., and Moberly, R., et al., Init. Repts. DSDP, 32: Washington (U.S. Govt. Printing Office), 579-676.

Foster, J. H., and Opdyke, N. D., 1970. Upper Miocene to Recent magnetic stratigraphy in deep-sea sediments. J. Geophys. Res., $75: 4465-4473$.

Gartner, S., 1973. Absolute chronology of the late Neogene calcareous nannofossil succession in the equatorial Pacific. Geol. Soc. Am. Bull., 84:2021-2034.

Gartner, S., and Bukry, D., 1974. Ceratolithus acutus Gartner and Bukry n. sp. and Ceratolithus amplificus Bukry and Percivalnomenclatural clarification. Tulane Stud. Geol. Paleontol., 11: $115-118$.

Hamilton, N., 1979. A paleomagnetic study of sediments from Site 397 northwest African continental margin. In von Rad, U., Ryan, W. B. F., et al., Init. Repts. DSDP, 47, Pt. 1: Washington (U.S. Govt. Printing Office), 463-477.
Haq, B. U., Berggren, W. A., and Van Couvering, J. A., 1977. Corrected age of the Pliocene/Pleistocene boundary. Nature, 269: 483-488.

Haq, B. U., Worsley, T. R., Burckle, L. H., et al., 1980. Late Miocene marine carbon-isotopic shift and synchroneity of some phytoplanktonic biostratigraphic events. Geology, 8:427-431.

Hays, J. D., 1970. Stratigraphy and evolutionary trends of radiolaria in North Pacific deep-sea sediments. Geol. Soc. Am. Mem., 126:185-218

Hays, J. D., and Berggren, W. A., 1971. Quaternary boundaries and correlations. In Funnell, B. M., and Riedel, W. R. (Eds.), The Micropaleontology of Oceans: London/New York (Cambridge Univ. Press), pp. 669-691.

Hays, J. D., Saito, T., Opdyke, N. D. et al., 1969. Pliocene-Pleistocene sediments of the equatorial Pacific: their paleomagnetic, biostratigraphic and climatic record. Geol. Soc. Am. Bull., 80: 1481-1514.

Hays, J. D., and Shackleton, N. J., 1976. Globally synchronous extinction of the radiolarian Stylatractus universus. Geology, 4: 649-652.

Hornibrook, N. de B., and Edwards, A. R., 1971. Integrated planktonic foraminiferal and calcareous nannoplankton datum levels in the New Zealand Cenozoic. In Farinacci, A. (Ed.), Proceedings of the Second Plankt. Conference, Rome, 1970: Rome (Tecnoscienza), pp. 649-657.

Hsü, K. J., Montadert, L., et al., 1978. Init. Repts. DSDP, 42, Pt. 1: Washington (U.S. Govt. Printing Office).

Hülsemann, J., 1966. On the routine analysis of carbonate in unconsolidated sediments. J. Sediment. Petrol., 36:622-625.

Jenkins, D. G., 1966. Planktonic foraminiferal datum planes in the Pacific and Trinidad Tertiary. N.Z. J. Geol. Geophys., 9:424-427. 1971. New Zealand Cenozoic planktonic foraminifera. N.Z. Geol. Surv. Paleont. Bull., 42:1-278.

Johnson, D. A., and Knoll, A. H., 1974. Absolute ages of Quaternary radiolarian datum levels in the equatorial Pacific. Quat. Res., 5:99-110.

Kaneps, A. G., 1973a. Cenozoic planktonic foraminifera from the eastern equatorial Pacific, Leg 16, Deep Sea Drilling Project. In van Andel, Tj. H., Heath, G. R., et al., Init. Repts. DSDP, 16: Washington (U.S. Govt. Printing Office), 713-746.

1973b. Carbonate chronology for Pliocene deep-sea sediments. In van Andel, Tj. H., Heath, G. R., et al., Init. Repts. DSDP, 16: Washington (U.S. Govt. Printing Office), 873-881.

Keigwin, L. D., Jr., 1976. Late Cenozoic planktonic foraminiferal biostratigraphy and paleoceanography of the Panama Basin. Micropaleont., 22:419-442.

1979. Late Cenozoic stable isotope stratigraphy and paleoceanography of DSDP sites from the east equatorial and central north Pacific Ocean. Earth Planet. Sci. Lett., 45:361-382.

Keigwin, L. D., Jr., and Shackleton, N. J., 1980. Uppermost Miocene carbon isotope stratigraphy of a piston core in the equatorial Pacific. Nature, 284:613-614.

Keigwin, L. D., Jr., and Thunell, R. C., 1979. Middle Pliocene climatic change in the western Mediterranean from faunal and oxygen isotopic trends. Nature, 282:294-296.

Keller, G., 1978. Late Neogene biostratigraphy and paleoceanography of DSDP Site 310 central North Pacific and correlation with the southwest Pacific. Mar. Micropaleont., 3:97-119.

1979. Late Neogene paleoceanography of the North Pacific DSDP Sites 173, 310, and 296. Mar. Micropaleont., 4: $159-172$.

1980. Middle to late Miocene planktonic foraminiferal datum levels and paleoceanography of the North and Southeastern Pacific Ocean. Mar. Micropaleont., 5:249-281.

Kennett, J. P., 1967. Recognition and correlation of the Kapitean stage (upper Miocene), New Zealand. N.Z. J. Geol. Geophys., 10:1051-1603.

1977. Cenozoic evolution of Antarctic glaciation, the circum-Antarctic Ocean, and their impact on global paleoceanography. J. Geophys. Res., 82:3843-3860.

Kennett, J. P., Shackleton, N. J., Margolis, S. V., et al., 1979. Late Cenozoic oxygen and carbon isotopic history and volcanic ash stratigraphy: DSDP Site 284, South Pacific. Am. J. Sci., 279: 52-69. 
Kennett, J. P., and Vella, P., 1975. Late Cenozoic planktonic foraminifera and paleoceanography at DSDP Site 284 in the cool subtropical South Pacific. In Kennett, J. P., Houtz, R. E., et al., Init. Repts. DSDP, 29: Washington (U.S. Govt. Printing Office), 769-799.

Kling, S. A., 1973. Radiolaria from the Eastern North Pacific, Deep Sea Drilling Project, Leg 18. In Kulm, L. D., von Huene, R., et al., Init. Repts. DSDP, 18: Washington (U.S. Govt. Printing Office), 617-671.

Koizumi, I., 1975. Neogene diatoms from the northwestern Pacific Ocean, Deep Sea Drilling Project. In Larson, R. L., Moberly, R., et al., Init. Repts. DSDP, 32: Washington (U.S. Govt. Printing Office), 865-889.

La Brecque, J. L., Kent, D. V., and Cande, S. C., 1977. Revised magnetic polarity time scale for Late Cretaceous and Cenozoic time. Geology, 5:330-335.

Larson, R. L., Moberly, R., et al., 1975. Init. Repts. DSDP, 32: Washington (U.S. Govt. Printing Office).

Luz, B., and Shackleton, N. J., 1975. $\mathrm{CaCO}_{3}$ solution in the tropical Pacific during the past 130,000 years: Cushman Found. Foraminiferal Res. Spec. Publ., 13:142-150.

McDougall, I., and Wensink, H., 1966. Paleomagnetism and geochronology of the Pliocene-Pleistocene lavas in Iceland. Earth Planet. Sci. Lett., 1:232-236.

Mankinen, E. A., and Dalrymple, G. B., 1979. Revised geomagnetic polarity time scale for the interval 0-5 m.y.B.P. J. Geophys. Res., $84: 615-626$.

Matthews, W. H., and Curtis, G. H., 1966. Date of the PliocenePleistocene boundary in New Zealand. Nature, 212:979-980.

Mayer, L. A., 1979. The origin and geologic setting of high-frequency acoustic reflectors in deep-sea carbonates [Ph.D. dissert.]. University of California, San Diego.

Mazzei, R., Raffi, I., Rio, D., et al., 1979. Calibration of late Neogene calcareous plankton datum planes with the paleomagnetic record of Site 397 and correlation with Moroccan and Mediterranean sections. In von Rad, U., Ryan, W. B. F., et al., Init. Repts. DSDP, 47, Pt. 1: Washington (U.S. Govt. Printing Office), 375389.

Mercer, J. H., 1976. Glacial history of southernmost South America. Quat. Res., 6:125-166.

Moore, T. C., Jr., Pisias, N. G., and Heath, G. R., 1977. Climate changes and lags in Pacific carbonate preservation, sea surface temperature and global ice volume. In Andersen, N. R., and Malahoff, A. (Eds.), The Fate of Fossil Fuel $\mathrm{CO}_{2}$ in the Oceans: New York (Plenum Press), pp. 145-165.

Morley, J. J., and Shackleton, N. J., 1978. Extension of the radiolarian Stylatractus universus as a biostratigraphic datum to the Atlantic Ocean. Geology, 6:309-311.

Ninkovich, D., and Shackleton, N. J., 1975. Distribution, stratigraphic position and age of ash layer " $L$ " in the Panama Basin region. Earth Planet. Sci. Lett., 27:20-34.

Oba, T., 1969. Biostratigraphy and isotopic paleotemperatures of some deep-sea cores from the Indian Ocean. Tohoku Univ. Sci. Rep., 2nd Ser. (Geol.), 41:129-195.

Olausson, E., 1960. Sediment cores from the Indian Ocean. Repts. Swed. Deep-Sea Exp., 1947-1948, 9:53-88.

1965. Evidence of climatic changes in North Atlantic deepsea cores, with remarks on isotopic paleotemperatures analysis. Prog. Oceanogr., 3:221-252.

Opdyke, N. D., 1972. Paleomagnetism of deep-sea cores. Rev. Geophys. Space Phys., 10:213-249.

Opdyke, N. D., Burckle, L. H., and Todd, A., 1974. The extension of the magnetic time scale in sediments of the central Pacific Ocean. Earth Planet. Sci. Lett., 22:300-306.

Parker, F. L., 1967. Late Tertiary biostratigraphy (planktonic foraminifera) of tropical Indo-Pacific deep-sea cores. Am. Paleontol. Bull., 52:115-203.

1971. Distribution of planktonic foraminifera in recent deep-sea sediment. In Funnell, B. M., and Riedel, W. R. (Eds.), The Micropaleontology of Oceans: Cambridge (Cambridge Univ. Press), pp. 289-307.

Pisias, N. G., Heath, G. R., and Moore, T. C., 1975. Lag times for oceanic responses to climatic changes. Nature, 256:716-717.
Poore, R. Z., 1979. Oligocene through Quaternary planktonic foraminiferal biostratigraphy of the North Atlantic: DSDP Leg 49. In Luyendyk, B. P., Cann, J. R., et al., Init. Repts. DSDP, 49: Washington (U.S. Govt. Printing Office), 447-517.

Rutten, M. G., and Wensink, H., 1960. Paleomagnetic dating, glaciations and the chronology of the Plio-Pleistocene in Iceland. Twenty-first International Geological Congress, Part 4, p. 62-70.

Ryan, W. B. F., Cita, M. B., Dreyfuss, R. M., et al., 1974. A paleomagnetic assignment of Neogene stage boundaries and the development of isochronous datum planes between the Mediterranean, the Pacific and Indian Oceans in order to investigate the response of the world oceans to the Mediterranean Salinity Crisis. Riv. Ital. Paleontol., 80:631-688.

Ryan, W. B. F., Hsu, K. J., et al., 1973. Init. Repts. DSDP, 13: Washington (U.S. Govt. Printing Office).

Saito, T., 1969. Late Cenozoic stage boundaries in deep-sea sediments. Geol. Soc. Am. Abstr. Prog., 7:289-290.

1977. Late Cenozoic planktonic foraminiferal datum levels: the present stage of knowledge toward accomplishing Pan-Pacific correlation. Proceedings of the First International Congress of Pacific Neogene Stratigraphy, Tokyo, 1976, pp. 61-80.

Saito, T., Burckle, L. H. and Hays, J. D., 1975. Late Miocene to Pleistocene biostratigraphy of equatorial Pacific sediments. In Saito, T., and Burckle, L. H. (Eds.), Late Neogene Epoch Boundaries: New York (Micropaleontol. Press), pp. 226-244.

Salvatorini, G., and Cita, M. B., 1979. Miocene foraminiferal stratigraphy, DSDP Site 397 (Cape Bojador, North Atlantic). In von Rad, U., Ryan, W.B. F., et al., Init. Repts. DSDP, 47, Pt. 1: Washington (U.S. Govt. Printing Office), 317-345.

Savin, S. M., Douglas, R. G., and Stehli, F. G., 1975. Tertiary marine paleotemperatures. Geol. Soc. Am. Bull., 86:1499-1510.

Savin, S. S., 1977. The history of the Earth's surface temperature during the past 100 million years. Ann. Rev. Earth Planet. Sci., 5:319-355.

Shackleton, N. J., 1977. Carbon-13 in Uvigerina: tropical rainforest history and the equatorial Pacific dissolution cycles. In Andersen, N. R., and Malahoff, A. (Eds.), The Fate of Fossil Fuel $\mathrm{CO}_{2}$ in the Oceans: New York (Plenum Press), pp. 401-427.

Shackleton, N. J., and Cita, M. B., 1979. Oxygen and carbon isotope stratigraphy of benthic foraminifers at Site 397: detailed history of climatic change during the late Neogene. In von Rad, U., Ryan, W. B. F., et al., Init. Repts. DSDP, 47, Pt. 1: Washington (U.S. Govt. Printing Office), 433-445.

Shackleton, N. J., and Kennett, J. P., 1975. Paleotemperature history of the Cenozoic and the initiation of Antarctic glaciation: Oxygen and carbon analyses in DSDP Sites 277, 279, and 281. In Kennett, J. P., Houtz, R. E., et al., Init. Repts. DSDP, 29: Washington (U.S. Govt. Printing Office), 743-755.

Shackleton, N. J., and Opdyke, N. D., 1973. Oxygen isotope and paleomagnetic stratigraphy of equatorial Pacific cores V28-238: oxygen isotope temperatures and ice volumes on a $10^{5}$ year and $10^{6}$ year scale. Quat. Res., 3:39-55.

1976. Oxygen isotope and paleomagnetic stratigraphy of Pacific core V28-239: late Pliocene to latest Pleistocene. Geol. Soc. Am. Mem., 145:449-464.

1977. Oxygen isotope and paleomagnetic evidence for early northern hemisphere glaciation. Nature, 270:216-219.

Shaw, A. B., 1964. Time in stratigraphy: New York (McGraw-Hill).

Stipp, J. J., Chappell, J. M. A., and McDougall, I., 1967. K/Ar age estimate of the Pliocene-Pleistocene boundary in New Zealand. Am. J. Sci., 265:462-474.

Stradner, H., 1973. Catalogue of calcareous nannoplankton from sediments of Neogene age in the Eastern Atlantic and Mediterranean Sea. In Ryan, W. B. F., Hsü, K. J., et al., Init. Repts. DSDP, 13: Washington (U.S. Govt. Printing Office), 1137-1199.

Theyer, F., and Hammond, S. R., 1974. Paleomagnetic polarity sequence and radiolarian zones, Brunhes to polarity Epoch 20. Earth Planet. Sci. Lett., 22:307-319.

Theyer, F., Mato, C. Y., and Hammond, S. R., 1978. Paleomagnetic and geochronologic calibration of latest Oligocene to Pliocene radiolarian events, equatorial Pacific. Mar. Micropaleont., 3: 377-395. 


\section{E. VINCENT}

Thierstein, H. R., Geitzenauer, K., Molfino, B., et al., 1977. Global synchroneity of late Quaternary coccolith datums: Validation by oxygen isotopes. Geology, 5:400-404.

Thompson, P. R., 1976. Planktonic foraminiferal dissolution and the progress towards a Pleistocene equatorial Pacific transfer function. J. Foraminiferal Res., 6:208-277.

Thompson, P. R., and Saito, T., 1974. Pacific Pleistocene sediments: Planktonic foraminifera dissolution cycles and geochronology. Geology, 2:333-335.

Thompson, P. R., and Sciarrillo, J. R., 1978. Planktonic foraminiferal biostratigraphy in the equatorial Pacific. Nature, 275:29-33.

Tracey, J. I., Jr., Sutton, G., et al., 1971. Init. Repts. DSDP, 8: Washington (U.S. Govt. Printing Office).

Vail, P. R., Mitchum, R. M., and Thompson, S., 1977. Seismic stratigraphy and global changes of sea level, part 4: global cycles of relative change of sea level. Am. Assoc. Petrol. Geol. Mem., 26:83-97.

Valencia, M. J., 1977. Pacific Pleistocene paleoclimatic stratigraphies: a comparative analysis of results. Quat. Res., 8:339-354.

van Andel, Tj. H., Heath, G. R., et al., 1973. Init. Repts. DSDP, 16: Washington (U.S. Govt. Printing Office).

van Andel, Tj. H., Heath, G. R., and Moore, T. C., 1975. Cenozoic tectonics, sedimentation and paleoceanography of the central Equatorial Pacific. Geol. Soc. Am. Memoir, 143:1-134.

van Andel, Tj. H., Thiede, J., Sclater, J. G., et al., 1977. Depositional history of the South Atlantic Ocean during the last 125 million years. J. Geol., 85:651-698.

Van Couvering, J. A., and Berggren, W. A., 1977, Biostratigraphical basis of the Neogene time scale. In Kauffman, E. G., and Hazel, J. E. (Eds.), Concepts and Methods of Biostratigraphy: Stroudsburg (Dowden, Hutchinson, Ross), pp. 283-306.
Van Couvering, J., Berggren, W. A., Drake, R. E., et al., 1976, The terminal Miocene event. Mar. Micropaleont., 1:263-286.

Vincent, E., 1975. Neogene planktonic foraminifera from the central North Pacific Leg 32, Deep Sea Drilling Project. In Larson, R. L., Moberly, R., et al., Init. Repts. DSDP, 32: Washington (U.S. Govt. Printing Office), 765-791.

, 1977a. Late Neogene planktonic foraminifera and paleoceanography of the central North Pacific. Proceedings of the First International Congress on Pacific Neogene Stratigraphy, Tokyo, 1976, pp. 407-408.

1977b. Indian Ocean Neogene planktonic foraminiferal biostratigraphy and its paleoceanographic implications. In Heirtzler, J. R., Bolli, H. M., Davies, T. A., et al. (Eds.), Indian Ocean Geology and Biostratigraphy: Washington (Am. Geophys. Union), pp. 469-584.

Vincent, E., Killingley, J. S., and Berger, W. H., 1980. The Magnetic Epoch-6 Carbon Shift: a change in the ocean's ${ }^{13} \mathrm{C} /{ }^{12} \mathrm{C}$ ratio 6.2 million years ago. Mar. Micropaleont., 5:185-203.

1981. Stable isotope composition of benthic foraminifera from the equatorial Pacific. Nature, 289:639-643.

Volat, J. L., Pastouret, L., and Vergnaud-Grazzini, C., 1980. Dissolution and carbonate fluctuations in Pleistocene deep-sea cores: a review. Mar. Geol., 34:1-28.

Westberg, M. J., and Riedel, W. R., 1978. Accuracy of radiolarian correlations in the Pacific Miocene. Micropaleont., 24:1-23.

Woodruff, F., Savin, S. M., and Douglas, R. G., 1981. Miocene stable isotopic record: a detailed deep Pacific Ocean study and its paleoclimatic implications. Science, 212:665-668.

Zagwign, W. H., 1974. The Pliocene-Pleistocene boundary in western and southern Europe. Boreas, 3:75-97. 